\title{
Outlining the thermal posdepositional evolution of the Ordovician successions of northwestern Argentina by clay mineral analysis, chlorite geothermometry and Kübler index
}

\author{
Margarita Do Campo ${ }^{1}$, Fernando Nieto ${ }^{2}$, Guillermo L. Albanesi ${ }^{3,4}$, Gladys Ortega $^{4}$, C. Rubén Monaldi ${ }^{5}$
}

\author{
${ }^{I}$ Instituto de Geocronología y Geología Isotópica (CONICET-Universidad de Buenos Aires) y Facultad de Ciencias Exactas y Naturales- \\ Universidad de Buenos Aires, Pabellón INGEIS, Ciudad Universitaria (1428) Buenos Aires. Argentina. \\ docampo@ingeis.uba.ar \\ ${ }^{2}$ Departamento de Mineralogía y Petrología and I.A.C.T., Universidad de Granada-CSIC, Avda. Fuentenueva s/n (18002) Granada, España. \\ nieto@ugr:es \\ ${ }^{3}$ Centro de Investigaciones en Ciencias de la Tierra (CONICET-Universidad Nacional de Córdoba. Avda. Velez Sarsfield 1611, CIC- \\ TERRA (X5016GCA) Córdoba Capital, Argentina. \\ glalbanesi@gmail.com \\ ${ }^{4}$ CONICET-Universidad Nacional de Córdoba, Avda. Velez Sarsfield 1611, CICTERRA (X5016GCA) Córdoba Capital, Argentina. \\ gladyscortega@gmail.com \\ ${ }^{5}$ CONICET-Universidad Nacional de Salta, Complejo Universitario Gral. San Martín - Avda. Bolivia 5150 (4400) Salta, Argentina. \\ crmonaldi@gmail.com
}

\begin{abstract}
The thermal post-depositional evolution of metapelitic and metavolcanic rocks of the upper CambrianOrdovician succession in the Central Andes of northwestern Argentina, was estimated through X ray diffraction of clay mineral analysis, Kübler Index (KI), SEM-EDS study of selected samples and chlorite geothermometry. The study area comprise five representative regions in Puna and Cordillera Oriental, namely at Sierra de Santa Victoria (Nazareno and Santa Victoria river areas), Cordón de los Siete Hermanos (Yavi), Sierra de Rinconada and Sierra de CochinocaEscaya. The paleotemperatures obtained with the chlorite geothermometer, in coincidence with KI values, show an E-W trend from diagenesis/low anchizone in the eastern flank of Sierra de Santa Victoria, to high anchizone/epizone in the Puna, with intermediate values in the western flank of Sierra de Santa Victoria. This trend, in conjunction with the development of slaty cleavage in the Ordovician rocks from Yavi, Sierra de Cochinoca-Escaya and western localities coincide with the limits proposed for the "Ocloyic deformation belt". The common occurrence of kaolinite in the slates and the metavolcanic rocks of Sierra de Cochinoca-Escaya, coupled with the substitution of chlorite by interstratified lower-temperature phases in most of these rocks and the occurrence of jarosite in a metadacite, indicate presence of hydrothermal fluids with high $\mathrm{H}^{+}$/cations ratios, producing acid type alteration (Utada, 1980), at temperatures between 100 and $\sim 300{ }^{\circ} \mathrm{C}$. The hydrothermal alteration should have been subsequent to the maximum burial and the attainment of epizonal metamorphism, and was very probably related with the posthumous activity of the Ordovician volcanic arc. The widespread occurrence of retrograde diagenesis products (smectite, kaolinite, as well as interstratified Chl/Sm and Chl/Vrm phases) in the anchizonal/epizonal metapelites of Sierra de Cochinoca-Escaya and Sierra de Rinconada constitute, up to our knowledge, the first report of an extensive hydrothermal activity affecting not only the metavolcanic rocks but also the Lower Ordovician sediments of northern Puna.
\end{abstract}

Keywords: Low-grade metamorphism, Retrodiagenesis, Geothermometry, Chlorite.

RESUMEN. Determinación de la historia térmica posdepositacional de las sucesiones ordovícicas del noroeste de Argentina mediante análisis de arcillas, geotermometría de la clorita e índice de Kübler. Estudios por difracción de rayos-X de rocas metapelíticas y metavolcánicas, complementadas con análisis textural a escala del SEM y microanálisis de muestras seleccionadas, con geotermometría de la clorita, han permitido delinear la historia diagenética-metamórfica prograda de las sucesiones del Cámbrico superior-Ordovícico de los Andes Centrales del NW de Argentina e identificar 
reacciones retrógradas. El estudio se centró en cinco localidades de Puna y Cordillera Oriental: sierra de Santa Victoria (zona de los ríos Nazareno y Santa Victoria), Cordón de los Siete Hermanos (Yavi), sierra de Rinconada y sierra de Cochinoca-Escaya. Las paleotemperaturas obtenidas mediante el geotermómetro de la clorita, coherentes con los valores obtenidos para el índice de Kübler, indican un aumento en las temperaturas de E a W, desde condiciones de diagénesis/ anquizona débil en el flanco oriental de la sierra de Santa Victoria, hasta anquizona fuerte/epizona en la Puna, con valores intermedios en el área de Yavi. Esta tendencia, así como la presencia de un clivaje metamórfico en las rocas ordovícicas de Yavi, sierra de Cochinoca-Escaya y sierra de la Rinconada coincide con los límites propuestos previamente, a partir de estudios estructurales y microtectónicos, para el "Cinturón de deformación Oclóyica". La presencia de caolinita en la mayor parte de las metapelitas y rocas metavolcánicas de las sierra de Cochinoca-Escaya, junto con la sustitución de la clorita por fases interestratificadas de menor temperatura y la presencia de jarosita en una metadacita, indican alteración por fluidos hidrotermales ácidos, a temperaturas entre $100 \mathrm{y} \sim 300{ }^{\circ} \mathrm{C}$. Esta alteración hidrotermal probablemente estuvo vinculada con la actividad póstuma del arco volcánico Ordovícico y sucedió con posterioridad a la etapa de máximo enterramiento, durante la que las rocas del sector septentrional de la Puna alcanzaron el metamorfismo de grado anquizona fuerte/epizona. La amplia distribución de fases asignables a retrodiagénesis (esmectita, caolinita, así como interstratificados Chl/Sm y Chl/Vrm) en las metapelitas de las sierras de Cochinoca-Escaya y Rinconada constituyen, hasta donde sabemos, el primer registro de una extensa actividad hidrotermal que afectó no solo las rocas metavolcánicas, sino también a los sedimentos del Ordovícico inferior del norte de la Puna.

Palabras clave: Metamorfismo de muy bajo grado, Retrodiagénesis, Geotermometría, Clorita.

\section{Introduction}

The upper Cambrian-Ordovician rock succession of the Central Andes of northwestern Argentina accumulated in a retroarc foreland basin that developed along the western margin of Gondwana (Ramos, 1999; Astini, 2003; Coira et al., 2009). In the last decades this rocks series has been the subject of many paleontological, sedimentological, structural and geochronological studies (e.g., Mon and Hongn, 1991; Bahlburg and Breitkreuz, 1991; Coira et al., 2001; Moya, 1999; Astini, 2003; Buatois et al., 2006; Moya, 2003; Zimmermann and Bahlburg, 2003; Ortega and Albanesi, 2005; Buatois et al., 2006; Astini, 2008; Albanesi et al., 2008; Voldman et al., 2013, 2016; Zeballo and Albanesi, 2013; Giuliano et al., 2013a; Albanesi et al., 2015; Toro et al., 2015). On the contrary, its burial/metamorphic evolution has only been briefly mentioned (Mon and Hongn, 1991; Zimmermann, 1999; Do Campo et al., 2013), lacking specific studies. The aim of this investigation is to identify prograde and retrograde clay mineral assemblages in key localities from Cordillera Oriental and Puna, in order to detect regional differences in burial conditions, to acquire a greater understanding of the evolution of the upper Cambrian-Ordovician basin.

Ordovician beds host several mineralized zones in the Sierra de Santa Victoria, and Sierra de Cochinoca-Escaya (Craig et al., 1995; Coira et al., 2001; Rubiolo et al., 2001), thus the clarification of their post-depositional evolution could be a key factor in prospection for mineral resources in northwestern Argentina, as well as to provide a constraint for improving geodynamic models of the western Gondwana margin during Paleozoic times.

In the realm of diagenesis and anchizone rough estimates of burial/metamorphic temperatures can be achieved with the study of clay assemblages and the Kübler Index (KI), but more precise determinations are seldom achieved. This is essentially due to specific causes; for instance, a lack of reliable index minerals, but also because thermodynamic equilibrium is seldom reached under these conditions. Nevertheless, even under non equilibrium conditions there is a general trend to decreasing disorder with increasing grade, which is consistent with a series of prograde transitions in which pelites pass through a sequence of metastable states as they approach stable chemical equilibrium(Merriman and Peacor, 1999). On the other hand, it has been demonstrated that clay-mineral assemblages formed under subgreenschist facies could be overprinted by retrograde reactions, "retrograde diagenesis" after Nieto et al. (2005), taken place at basin scale via pervasive fluids under open-system conditions. Thus X-ray diffraction (XRD)-based studies of pelitic rocks should be supplemented by textural studies under the scanning electron microscope (SEM) in order to detect evidences of retrograde reactions and thus discriminate between clay-minerals of prograde or retrograde origin.

On the other hand, the empirical geothermometers based on the ${ }^{\mathrm{IV}} \mathrm{Al}$ content of chlorites in 
sub-greenschist $\left(<400{ }^{\circ} \mathrm{C}\right)$ conditions (Cathelineau, 1988; Jowett, 1991; De Caritat et al., 1993) have been widely employed, mainly due to their simplicity, even though they frequently show a wide scatter reflecting the lack of thermodynamic equilibrium (De Caritat et al., 1993). Moreover this method was severely questioned by different authors (Hillier and Velde, 1991; De Caritat et al., 1993; López Munguira et al., 2002). More recently, several thermodynamicbased chlorite geothermometers for di-trioctahedral chlorite have been proposed (Bourdelle et al., 2013; Lanari et al., 2014; Bourdelle and Cathelineau, 2015).

The aim of this paper is to constrain the thermal post depositional evolution of the lower Paleozoic successions of northwestern Argentina integrating several inorganic indices, including determination of clay mineral assemblages by XRD, Kübler Index (KI), SEM study of selected samples by backscattered electron images (BSE) and energy dispersive $\mathrm{X}$ ray (EDS) and chlorite geothermometry, coupled with previously published data on conodont Color Alteration Index (CAI) (Giuliano et al., 2013a, b; Voldman et al., 2013; Voldman et al., 2016). This study concentrates on five representative areas of Lower Palaeozoic rocks exposures in the northeastern Puna and Cordillera Oriental, namely at Sierra de Santa Victoria (Nazareno and Santa Victoria river areas), Cordón de los Siete Hermanos (Yavi), Sierra de Rinconada and Sierra de Cochinoca-Escaya.

\section{Geological framework}

The upper Cambrian-Ordovician rock succession of the Central Andes of northwestern Argentina accumulated in a retroarc foreland basin that developed along the western margin of Gondwana (Ramos, 1999; Astini, 2003; Coira et al., 2009). The rock series that surpasses $5,000 \mathrm{~m}$ in thickness is exposed in the Puna, Cordillera Oriental, and Sierras Subandinas morphotectonic provinces of Argentina. Nevertheless, as it was previously mentioned, this paper is focused in the Ordovician strata cropping out in northeastern Puna and northern Cordillera Oriental (Fig. 1). The basement of the study area is represented by the Vendian-lower Cambrian Puncoviscana Formation (Turner, 1960), mainly composed of a pelite-greywacke turbidite sequence, which was affected by very low-grade metamorphism and polyphase deformation. This unit is unconformably overlain by middle-upper
Cambrian shallow platform quartzites, sandstones and red to greenish shales, with cross stratification and trace fossils (dominantly Skolithos sp.) of the Mesón Group (Turner, 1960). The Mesón Group is, in turn, unconformably covered by the upper Cambrian-Lower Ordovician rock succession. We will adopt the widely accepted stratigraphic nomenclature that assigned the upper Cambrian-Ordovician strata from Cordillera Oriental and the siliciclastic levels from the northeastern Puna to the Santa Victoria Group (Turner, 1964), which consists of the Santa Rosita (upper Cambrian-Tremadocian) and the Acoite (upper Tremadocian?-Floian) formations (Rubiolo et al., 2001; Astini, 2003; Buatois and Mángano, 2003; Voldman et al., 2016). In the Puna region, the fossiliferous siliciclastic marine sediments assignable to Upper Cambrian, Tremadocian to Floian interdigitate with synsedimentary lavas and subvolcanic intrusives of the Eastern Puna Eruptive Belt (Méndez et al., 1973; Giuliano et al., 2013b) that were grouped into the Magmatic-Sedimentary Cochinoca-Escaya Complex (Coira et al., 1999; Coira et al., 2001).

The Santa Rosita Formation crops out in the Cordillera Oriental (Fig. 1). It mainly comprises greenish grey shale levels with intercalations of thin micaceous white sandstone beds, and pale gray silicified sandstone beds up to $2 \mathrm{~m}$ thick. Shale levels could contain disperse pyrite and calcareous concretions. This succession was formerly considered as having formed in fully open marine environments; however, more recent studies in several localities from Cordillera Oriental revealed a complex depositional history including a wide range of sedimentary environments (Buatois and Mángano, 2003), that these authors grouped in two main facies associations, one for the fluvio-estuarine deposits and the other one for the open-marine deposits. Furthermore, based on a detailed sedimentologic, biostratigraphic and sequence stratigraphic study, Buatois et al. (2006) identified several transgressive-regressive cycles for this unit in the Tilcara Range. The succession also comprises a basal conglomerate, even though in some localities the conglomerate is absent, and the basal bed is a coarse-grained sandstone (Rubiolo et al., 2001).

The Acoite Formation is exposed in elongated belts with a general NNE-SSO strike in Cordillera Oriental and eastern Puna (Fig. 1). In the Sierra de Santa Victoria, the succession is well exposed along the Santa Victoria River, immediately to the west of 
the homonymous village. In the northern Puna these sediments are exposed in the Sierra de Rinconada from the Argentina-Bolivia border to the south, and to the west in Sierra de Carahuasi.

In Cordillera Oriental the Acoite Formation mainly comprises thick greenish to dark grey shale levels with interbeddings of white-grayish quartzites and marly shales, blue-grayish marls, scarce fossiliferous limestones, and dark limestones (Rubiolo et al., 2001). The sandstone-shale ratio is approximately $1: 1$ at the lower part of the section, decreasing to $1: 2$ upwards, a ratio that prevails in a major part of the section. In northern Puna (Sierra de Rinconada) the lack of limestone levels is remarkable (Coira et al., 2001), the sequence is characterized by an upwardthickening and coarsening stratal pattern (Bahlburg, 1990), and by the occurrence of subordinate coarse sandstones to micro conglomerate beds.
The Magmatic-Sedimentary Cochinoca-Escaya Complex (Coira et al., 2001) comprises sandstonepelite succession along with syndepositional bimodal volcanic and subvolcanic rocks; mainly dacitic lavas, hyaloclastites, domes-cryptodomes and minor basic-spilitic lavas, massive and in pillows (Coira and Koukharsky, 1991), with gabbro-basalt sills and dikes (Coira et al., 1999, 2009). The type locality of this units located to the southwest of the study area, in the western flank of Sierra de Quichagua and the Eastern flank of Sierra de Queta (Coira et al., 2001). Within the study area this unit is exposed in the northeastern Puna in Sierra de Cochinoca-Escaya (Fig. 1). In the eastern flank of this range dacitic lavas and hialoclastites 10 to $25 \mathrm{~m}$ thick occur; furthermore, the occurrence of globular peperitic levels, 5 to $10 \mathrm{~cm}$ thick, near dacitic sills tops, demonstrate the synsedimentary character of

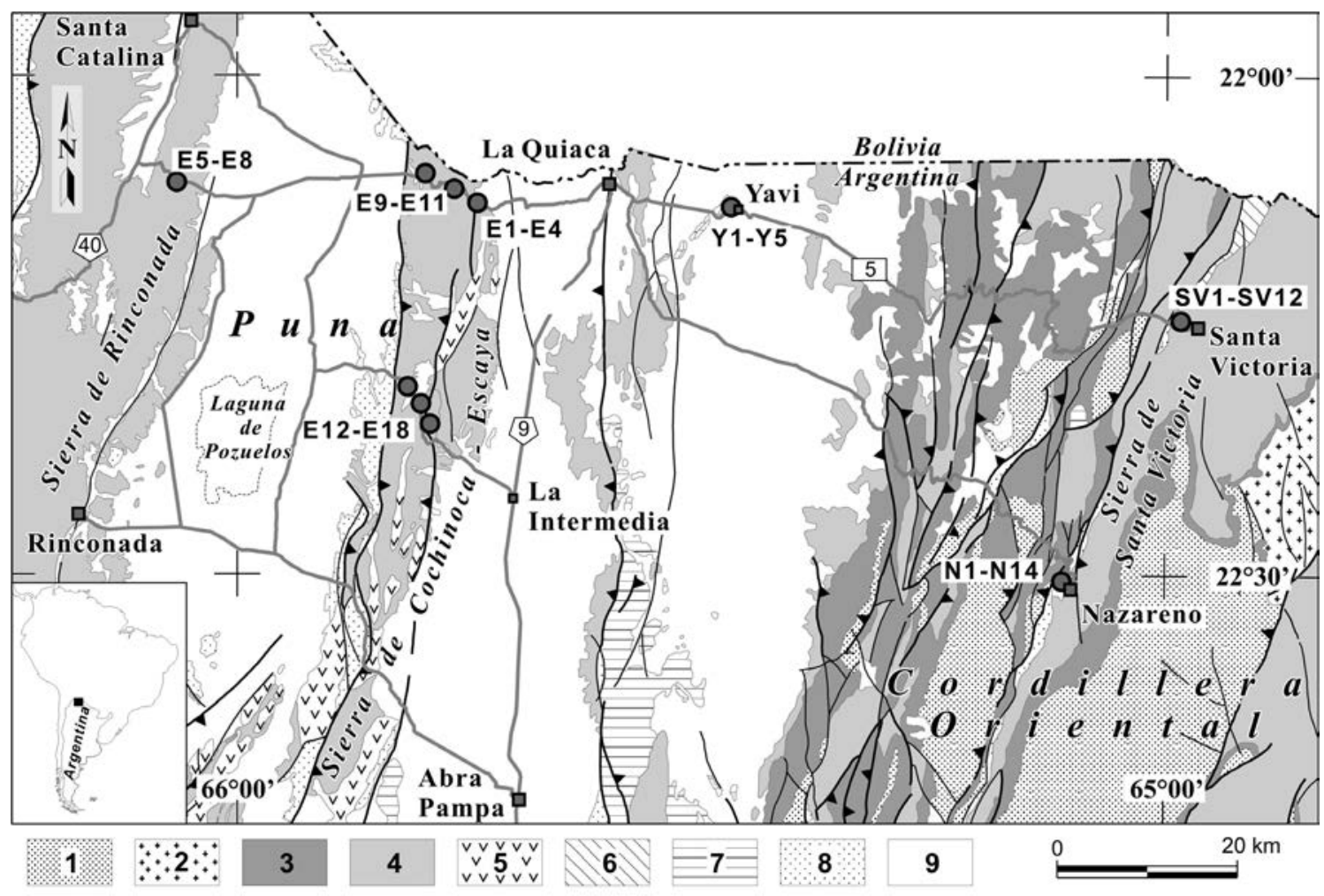

FIG. 1. Geological map of the study area, showing sampling localities with conodont-graptolite biostratigraphic control. Legend: 1. Puncoviscana Formation (upper Proterozoic-lowest Cambrian); 2. Cañaní Formation (lower Cambrian); 3. Mesón Group (middle-upper Cambrian); 4. Santa Victoria Group (uppermost Cambrian-Lower Ordovician); 5. Magmatic-Sedimentary Cochinoca-Escaya Complex (Ordovician); 6. Lipeón Formation (Silurian); 7. Salta Group (Cretaceous-lowest Paleogene); 8. Paleogene-Neogene; 9. Quaternary. 
the volcanism (Rubiolo et al., 2001). Based on the texture of these rocks, Coira and Koukharsky (1994) and Coira (1996) inferred an origin by non explosive submarine volcanism, and that the fragmentation must have been originated from hydroclastic processes.

The Ordovician rocks are related with several mineralized zones in Sierra de Cochinoca-Escaya and Rinconada comprising mineralized quartz veins, gold bearing "saddle reefs" with $\mathrm{As}, \mathrm{Fe}, \mathrm{Cu}, \mathrm{Pb}, \mathrm{Zn}$, Sb sulfides and sulfosalts of silver (Craig et al., 1995; Coira et al., 2001).

The Ordovician succession was folded with a simple structural style (Mon and Hongn, 1991). The intensity of folding increases gradually westward; actually, Ordovician rocks depict a conspicuous axial plane cleavage and penetrative deformation in outcrops from Puna (Mon and Hongn, 1991). On the contrary, to the east slaty cleavage is absent and beds of the Santa Victoria Group are separated by a slight discordance from the overlying Paleozoic successions (Hongn, 1992). At $22^{\circ} \mathrm{S}$ Lat. the transition zone between both areas is located to the west of Sierra de Santa Victoria, near the village of Yavi (Hongn, personal communication, 2016). The outcrops of Ordovician beds depicting tight folds and penetrative deformation were included by Mon and Hongn (1991) in the "Ocloyic belt", as the age of the deformation was traditionally attributed to the Ocloyic Phase or Orogeny (Late Ordovician) (Turner and Méndez, 1975; Turner and Mon, 1979; Mon and Salfity, 1995, among others). However, later investigations have unraveled a more complex scenario. On one hand, intra-Ordovician deformation was documented in several outcrops of Lower Ordovician rocks in the transition between Puna and Cordillera Oriental, as well as in the area of Salar de Rincón in western Puna (Bahlburg, 1990; Bahlburg and Hervé, 1997; Moya, 1999; Astini, 2003; Hongn and Vacari, 2008). On the other hand, Moya (1999, 2015) questioned the classical view that ascribed the deformation affecting the Santa Victoria Group deposits and equivalent units in northern Argentina to a Late Ordovician Orogeny. This author proposed that the deformation could be younger, as there is no evidence of an angular unconformity separating the Upper Ordovician deposits outcropping in Cordillera Oriental from the overlying Lower Paleozoic sequences. Likewise, K-Ar ages of fine-grained micas obtained for Ordovician very low grade metapelites of the Eastern Cordillera of southern Bolivia rule out the existence of orogenic activity during the Late Ordovician and attribute the deformation to a Late Devonian-Early-Carboniferous (Kley and Reinhardt, 1994; Tawackoli et al., 1996) or Late Carboniferous-Early Permian orogenic episode (Jacobshagen et al., 2002).

The study area comprises localities from northern Cordillera Oriental and northeastern Puna, where Ordovician rocks present excellent exposures.

\section{Sampling and analytical techniques}

Samples were collected with conodont-graptolite biostratigraphic control in representative outcrops at Sierra de Santa Victoria (Nazareno and Santa Victoria River), Cordón de los Siete Hermanos (Yavi), Sierra de Cochinoca-Escaya, and Sierra de Rinconada (Fig. 1). Pelitic levels were sampled in all localities, whereas that at the southern sector of Sierra de Cochinoca-Escaya sampling also comprises volcanic rocks corresponding to the Magmatic-Sedimentary Cochinoca-Escaya Complex (Coira et al., 2001). Yavi is located in the eastern border of the Ocloyic belt, in the sense of Mon and Hongn (1991). A summary of the samples studied, including location, lithology, biostratigraphy and lithostratigraphy is shown in table 1. At Sierra de Santa Victoria (Nazareno, Santa Victoria River) mudstones corresponding to the Santa Rosita Formation were sampled (Paltodus deltifer conodont Zone, Voldman et al., 2013, and Bryograptus kjerulfi, Aorograptus victoriae, Araneograptus murrayi and Hunnegraptus copiosus graptolite zones, Giuliano et al., 2013a; Toro et al., 2015, middle-upper Tremadocian). At Cordón de los Siete Hermanos (Yavi), western flank of Sierra de Santa Victoria, the slates sampled correspond to the Acoite Formation (Didymograptellus bifidus Zone upper Floian) (Vento, 2013). At Sierra de CochinocaEscaya the sampled pelitic levels correspond to the Sedimentary Facies of the Magmatic-Sedimentary Cochinoca-Escaya Complex (Rubiolo et al., 2001), in the northern sector at cuesta del Toquero (near the village of Tafna) biostratigraphic information refer to the Undulograptus austrodentatus Zone, lower Darriwillian (Middle Ordovician), correlative with the Coquena Formation of the western Puna (Gutiérrez-Marco et al., 1996). At the southern sector of Sierra de Cochinoca-Escaya sampling also comprises volcanic rocks, a fine-grained metadacite (E 15), white in hand specimen, and metaandesitic 


\begin{tabular}{|c|c|c|c|c|c|c|c|c|c|c|c|c|c|c|c|c|}
\hline \multirow{2}{*}{$\begin{array}{c}\text { Geologic } \\
\text { Unit }\end{array}$} & \multirow{2}{*}{ Biostratigraphy } & \multirow{2}{*}{\multicolumn{2}{|c|}{ Locality }} & \multirow{2}{*}{ Sample } & \multirow{2}{*}{ Lithology } & \multicolumn{8}{|c|}{ Mineralogy } & \multirow{2}{*}{$\mathbf{K I} \mathbf{I}_{\text {(cIs) }}$} & \multirow[b]{2}{*}{ Metapelitic zone } & \multirow[b]{2}{*}{ CAI } \\
\hline & & & & & & III-Ms & Chl & Kln & Sm & Mixed Layers & Qtz & Plg & kfs & & & \\
\hline \multirow{17}{*}{ 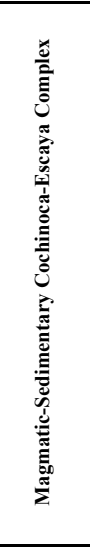 } & \multirow{11}{*}{$\begin{array}{l}\text { Undulograptus } \\
\text { austrodentatus Zone } \\
\text { Lower Darriwilian }\end{array}$} & \multirow{4}{*}{\multicolumn{2}{|c|}{$\begin{array}{c}\text { Northern Sa. de Cochinoca- } \\
\text { Escaya }\end{array}$}} & $\overline{\text { E1 }}$ & slate & & & & & $\mathrm{Chl} / \mathrm{Mi}, \mathrm{Chl} / \mathrm{Sm}, \mathrm{Chl} / \mathrm{Vrm}$ & & & & 0.28 & \multirow{4}{*}{ Epizone } & \\
\hline & & & & E2 & slate & & & & & $\mathrm{Chl} / \mathrm{Sm}$ & & & & 0.29 & & \\
\hline & & & & E3 & slate & & & & & $\mathrm{Chl} / \mathrm{Vrm}$ & & & & 0.27 & & \\
\hline & & & & E4 & slate & & & & & & & & & n.d. & & \\
\hline & & \multirow{7}{*}{\multicolumn{2}{|c|}{$\begin{array}{l}\text { Northern Sa. de Cochinoca- } \\
\text { Escaya }\end{array}$}} & E5 & $\begin{array}{l}\text { slate } \\
\text { s. }\end{array}$ & & & & & & & & & 0.32 & \multirow{7}{*}{ High Anchizone } & \\
\hline & & & & E6 & slate & & & & & & & & & 0.33 & & \\
\hline & & & & E7 & slate & & & & & & & & & n.d. & & \\
\hline & & & & E8 & slate & & & & & $\mathrm{Chl} / \mathrm{Sm}, \mathrm{Chl} / \mathrm{Vrm}$ & & & & 0.32 & & \\
\hline & & & & E9 & slate & & & & & & & & & 0.34 & & \\
\hline & & & & E10 & slate & & & & & $\mathrm{Chl} / \mathrm{Vrm}$ & & & & 0.35 & & \\
\hline & & & & E11 & slate & & & & & $\mathrm{Chl} / \mathrm{Sm}$ & & & & 0.35 & & \\
\hline & \multirow[t]{6}{*}{ Upper Tremadocian to Floian } & \multirow{6}{*}{\multicolumn{2}{|c|}{$\begin{array}{c}\text { Southern Sa. de Cochinoca- } \\
\text { Escaya }\end{array}$}} & $\overline{E 12}$ & $\begin{array}{l}\text { slate } \\
\text { s. }\end{array}$ & & & & & $\mathrm{Chl} / \mathrm{Sm} ?$ & & & & 0.32 & High Anchizone & \\
\hline & & & & E13 & slate & & & & & & & & & 0.28 & & \\
\hline & & & & E14 & slate & & & & & & & & & 0.27 & & \\
\hline & & & & E15 & metadacite & & & & & & & & & 0.30 & Epizone & \\
\hline & & & & $\begin{array}{l}\text { E16 } \\
\text { E17 }\end{array}$ & $\begin{array}{c}\text { slate } \\
\text { metaandesite }\end{array}$ & & & & & Complex ML & & & & 0.31 & & \\
\hline & & & & E18 & slate & & & & & Complex ML & & & & 0.23 & & \\
\hline \multirow{3}{*}{ 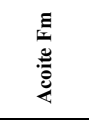 } & \multirow{3}{*}{$\begin{array}{c}\text { Didymograptellus bifidus Zone } \\
\text { Upper Floian }\end{array}$} & \multirow{3}{*}{\multicolumn{2}{|c|}{ Cdón. 7 Hermanos (Yavi) }} & $\mathrm{Y} 1$ & slate & & & & & & & & & 0.33 & High Anchizone & \\
\hline & & & & Y2 & slate & & ? & & & & & & & 0.30 & Epizone & \\
\hline & & & & $\begin{array}{l}\text { Y5 } \\
\text { Y6 }\end{array}$ & $\begin{array}{l}\text { slate } \\
\text { slate }\end{array}$ & & & & & & & & & $\begin{array}{l}0.36 \\
0.35\end{array}$ & High Anchizone & \\
\hline \multirow{16}{*}{ 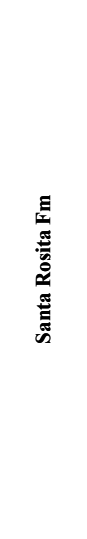 } & & & & N1 & mudstone & & & & & & & & & 0.66 & & \\
\hline & & & & $\mathrm{N} 2$ & mudstone & & & & & & & & & 0.61 & Diagenesis & 3 \\
\hline & & & & N3 & mudstone & & & & & & & & & 0.53 & & \\
\hline & & & & $\mathrm{N} 4$ & mudstone & & & & & & & & & n.d. & & \\
\hline & & & & N5 & mudstone & & & & & & & & & n.d. & & \\
\hline & & 嵒 & 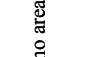 & $\begin{array}{l}\mathrm{N} 6 \\
\mathrm{~N} 7\end{array}$ & $\begin{array}{l}\text { mudstone } \\
\text { mudstone }\end{array}$ & & & & & & & & & $\begin{array}{l}0.50 \\
\text { n.d. }\end{array}$ & Low anchizone & $3-4$ \\
\hline & & : & 总 & N8 & mudstone & & & & & & & & & 0,47 & & \\
\hline & Paltodus deltifer Zone Upper & 吾 & 尝 & N9 & mudstone & & & & & & & & & 0.58 & & \\
\hline & Tremadocian & 胥 & & N10 & mudstone & & & & & & & & & 0.50 & Low anchizone & \\
\hline & & $\stackrel{\pi}{\pi}$ & & $\begin{array}{l}\text { N11 } \\
\text { N12 }\end{array}$ & $\begin{array}{l}\text { mudstone } \\
\text { mudstone }\end{array}$ & & & & & & & & & $\begin{array}{l}0.55 \\
\text { n.d. }\end{array}$ & Diagenesis & 3 \\
\hline & & & & N13 & mudstone & & & & & & & & & 0.66 & Diagenesis & \\
\hline & & & & N14 & mudstone & & & & & & & & & n.d. & & \\
\hline & & & פू & $\begin{array}{l}\text { SV } 1 \\
\end{array}$ & mudstone & & $?$ & & & $\mathrm{Chl} / \mathrm{Sm} ?$ & & & & 0.41 & High anchizone & \\
\hline & & & 政 & SV 8 & mudstone & & & ? & & $\mathrm{I} / \mathrm{Sm}$ & & & & 0.69 & Diagenesis & 3 \\
\hline & & & ๓็ & SV10 & mudstone & & $?$ & & & $\mathrm{Ch} / \mathrm{Sm} ?$ & & & & 0.47 & Low anchizone & \\
\hline & & & & SV12 & mudstone & & & ? & & $\mathrm{I} / \mathrm{Sm}$ & & & & 0.31 & Epizone & \\
\hline
\end{tabular}

Kübler Index (KI) is expressed in CIS scale (Warr and Rice, 1994). Metapelitic zones were in ferred from KI data, limiting values for the low-grade and high-grade boundary of the anchizone are 0.52 and $0.32^{\circ} \Delta 2 \theta$ respectively. CAI values from Giuliano et al., 2013a and Voldman et al., 2013, 2016; the stratigraphic sections sampled for conodonts at Yavi and Cochinoca-Escaya and Rinconada ranges, were barren of these microfossils. Mineral associations do not necessarily represent equilibrium assemblages. Abbreviations for minerals names according to Whitney and Evans (2010). 
pillow lava (E17) referable to the Magmatic Facies of the Magmatic-Sedimentary Cochinoca-Escaya Complex (Coira et al., 2001).

The mineralogical composition of $<2 \mu \mathrm{m}$ subfraction, including measuring of KI, was performed for 40 samples by X-ray diffraction (XRD) using an $\mathrm{X}$ 'Pert Pro diffractometer $(\mathrm{CuK} \alpha$ radiation, 40kV, 40mA) (Departamento de Físico Química, UNC, Argentina), and a PANalytical X'Pert Pro diffractometer $(\mathrm{CuK} \alpha$ radiation, $45 \mathrm{kV}, 40 \mathrm{~mA})$ equipped with an $\mathrm{X}^{\prime}$ Celerator solid-state linear detector (Departmento de Mineralogía y Petrología, Universidad de Granada). Clay sub-samples $(<2 \mu \mathrm{m})$ were prepared in accordance with the guidelines of Moore and Reynolds (1997). The Kübler Index (KI) was measured in glycolated orientated aggregates, and CIS values (Crystallinity Index Standard, Warr and Rice, 1994) were established from the regression equation for the $X$ 'Pert Pro diffractometer $(0.1106 x+0.0955 \mathrm{R} 2=0.9573)$. The upper and lower boundary limits of the anchizone in the CIS scale are taken as $0.32^{\circ} \Delta 2 \theta$ and $0.52^{\circ} \Delta 2 \theta$, respectively, following the recommendations of the Round Table discussion at the Mid European Clay Conference (Warr and Ferreiro Mälmann, 2014). Some XRD traces showing complex mixture of mixed-layered minerals were deconvoluted with the MacDiff software.

We performed standard petrographical analyses to determine lithology, general composition, and primary and metamorphic foliations. Afterwards, seven representative samples, five metapelites (N4, Y1, Y5, E1 and E4), a fine-grained metadacite (E 15) and a metaandesitic pillow lava (E17), were chosen for detailed study at the SEM scale and EDS microanalyses, employing polished thin sections, using back-scattered electron imaging and X-ray dispersive (EDS) analysis with a ZEISS DSM 950 scanning electron microscope (Centro de Instrumentos Científicos, Universidad de Granada, CIC). Atomic concentration ratios were converted into formulae according to stoichiometry. Accordingly, the structural formulae of dioctahedral micas and chlorite were calculated, on the basis of $22\left(\mathrm{O}_{10}(\mathrm{OH})_{2}\right)$ and 28 negative charges $\left(\mathrm{O}_{10}(\mathrm{OH})_{8}\right)$, respectively; whereas that structural formulae of chlorite bearing mixedlayers were calculated considering 25 oxygen atoms (14 of chlorite +11 of swelling layers). Abbreviations of minerals according to Whitney and Evans (2010), in addition to this, $\mathrm{I} / \mathrm{Sm}, \mathrm{Chl} / \mathrm{Sm}, \mathrm{Chl} / \mathrm{Vrm}, \mathrm{Bt} / \mathrm{Chl}$ and $\mathrm{Chl} / \mathrm{Mi}$ account for illite/smectite, chlorite/ smectite, chlorite/vermiculite, biotite/chlorite and chlorite/mica mixed-layers, respectively.

\section{Results}

\subsection{X-ray diffraction-Kübler index}

\subsubsection{Cordillera Oriental-Sierra de Santa Victoria}

The phyllosilicates identified in mudstones from the Nazareno area were illite-muscovite and chlorite, with subordinate kaolinite in few cases (Table 1, Fig. 2a). The KI values for this area are in the range of deep diagenesis-low anchizone $\left(0.69\right.$ to $\left.0.47^{\circ} \Delta 2 \theta\right)$. On the other hand, mudstones from the Santa Victoria River show more complex assemblages comprising illite-muscovite $\pm \mathrm{Chl} / \mathrm{Sm} \pm \mathrm{I} /$ Sm (Fig. 2b) and a wide range of KI values (0.69 to $0.31^{\circ} \Delta 2 \theta$ ), corresponding to deep diagenesis to epizone.

\subsubsection{Cordillera Oriental-Cordón Siete Hermanos (Yavi)}

Clay fractions consist of illite-muscovite \pm kaolinite \pm chlorite \pm smectite; whereas KI values are in the range of high anchizone to epizone (0.30$\left.0.36^{\circ} \Delta 2 \theta\right)$.

\subsubsection{Northeastern Puna-Sierra de Cochinoca- Escaya and Sierra de Rinconada}

Three groups of samples can be distinguished according to their clay-mineral assemblages. In the first group the clay fraction is composed by illite-muscovite and chlorite (Fig. 2c, samples: E4, E5 and E9). Other group consists of illite-muscovite+kaolinite + smectite (samples E6, E7 and E15). On the other hand, most of the samples show complex clay-minerals assemblages comprising: illite-muscovite \pm chlorite $\pm \mathrm{Chl} / \mathrm{Sm} \pm \mathrm{Chl} /$ $\mathrm{Vrm} \pm$ kaolinite $\pm \mathrm{Chl} / \mathrm{Mi} \pm$ smectite. For example, the XRD pattern of the air-dried oriented mount of slate E 18 depicts the characteristic reflections of illitemuscovite and kaolinite, but also an almost rational series of reflections at $13.36,8.53,6.70,5.22$, and $4.49 \AA$, that shift towards slightly higher values after the ethylene glycol (EG) treatment, indicating a nearly regular mixed-layer containing an expandable component (Fig. 2d).

The KI values obtained for pelites from northeastern Puna are in the range of high anchizone to epizone $\left(0.23-0.35^{\circ} \Delta 2 \theta\right)$. 

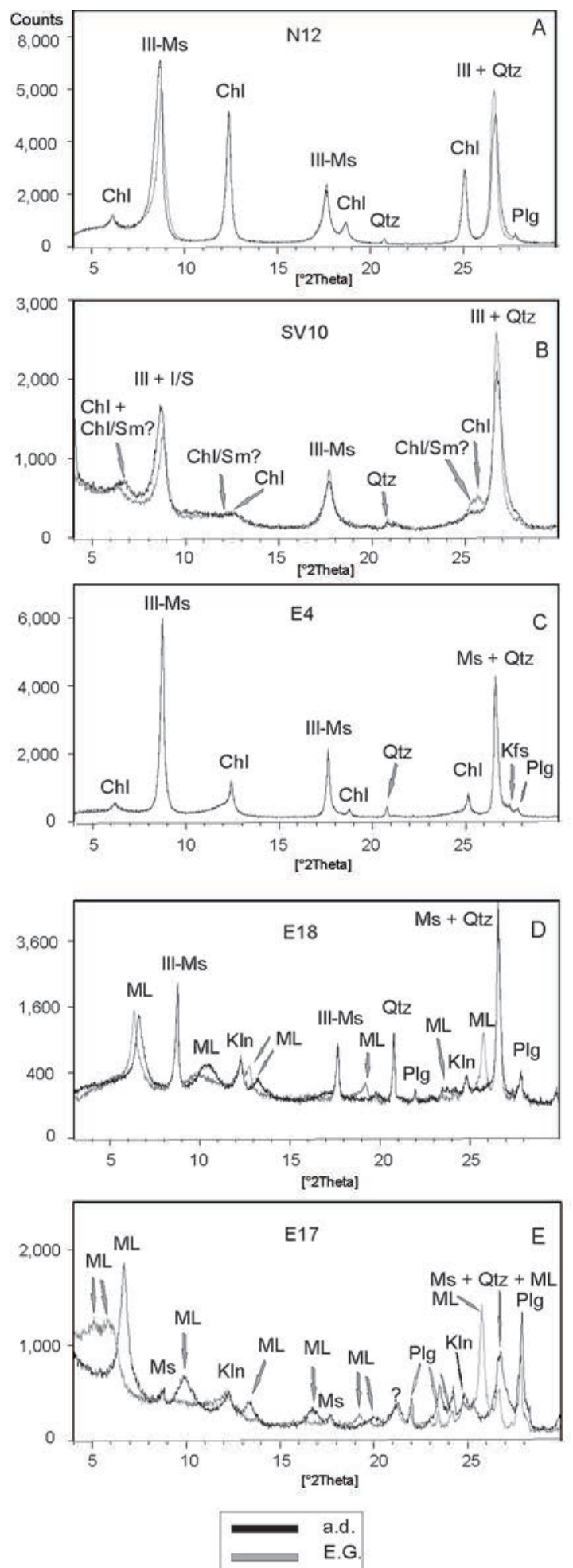

FIG. 2. XRD air-dried (a.d.) and ethylene-glycol (E.G.) solvated patterns of $<2 \mathrm{~m}$ sub-samples from metapelites: A. N12; B. SV10; C. E 4; D. E 18; and metaandesite; E. E 17. Abbreviations for minerals names according to Whitney and Evans (2010); ML: mixed-layers. 
The metaandesite (E17) comprises abundant mixed-layers plus dioctahedral mica, kaolinite, quartz, potassium feldspar, plagioclase and goethite (Fig. 2e). In the XRD pattern of the air-dried oriented mount mixed-layers produce an almost rational series of reflections at $13.20,8.87,6.66,5.35$, and $4.41 \AA$, that shift towards slightly higher values after the EG treatment indicating a nearly regular mixed-layer containing an expandable component, quite similar to the series of reflections appearing in the XRD pattern of the slate taken at the same outcrop (Fig. 2d, E18). Furthermore, in the EG-treated pattern of the metaandesite also appear an irrational series of reflections at 5.61, 4.76, 3.89 and $3.52 \AA$ that probably correspond to a random mixed-layer. The kind of layers composing these mixed-layers will be discussed in a next section. This sample shows a KI value of $0.31^{\circ} \Delta 2 \theta$ indicating epizone, likewise most of the slates from the southern area of Sierra de Cochinoca-Escaya.

\subsection{Optical microscopy and SEM}

\subsubsection{N4 (Cordillera Oriental)}

A rough anastomosing bedding-parallel microfabric $\left(\mathrm{S}_{0}\right)$ defined by a granulometric-compositional layering and the preferred orientation of chlorite and micaflakes can be observed by optical microscopy and by means of the SEM (Figs. 3a and 4a). Phyllosilicate-rich bands are composed by elongate chlorite grains 15 to $45 \mu \mathrm{m}$ long and dioctahedral micas 10 to $50 \mu \mathrm{m}$ long, probably detrital in origin (Fig. 4a). Interleaved phyllosilicate grains are common. The alternating
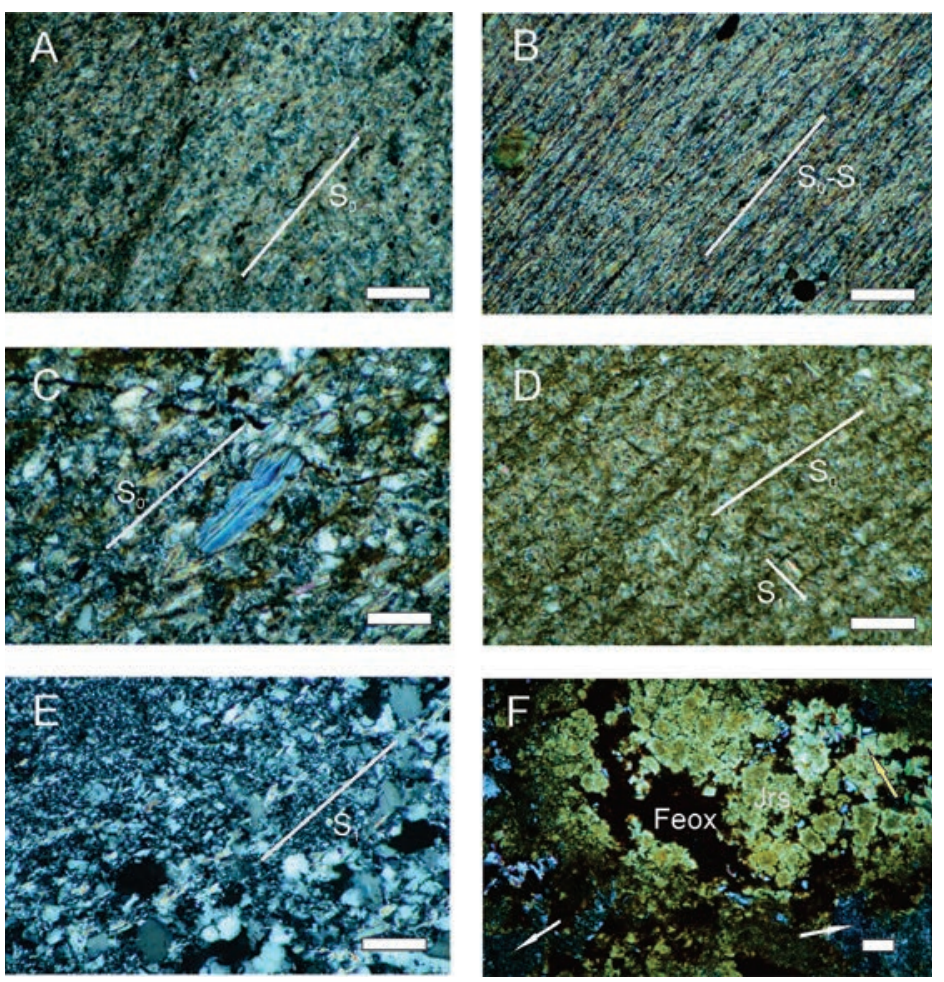

FIG. 3. Optical microscope images (crossed nicols), microstructural features of metapelites and metavolcanic rocks: A. Mudstone showing a rough anastomosing sedimentary layering $\left(\mathrm{S}_{0}\right)$ defined by a granulometric-compositional layering and the preferred orientation of chlorite and mica flakes $(\mathrm{N} 4)$. B. Slate depicting a diagenetic smooth parallel microfabric $\left(\mathrm{S}_{0}\right)$ defined by veinlets of iron oxides and detrital phyllosilicate grains (Y1). C. Slate showing a rough anastomosing spaced cleavage $\left(\mathrm{S}_{1}\right)$ parallel to the sedimentary layering $\left(\mathrm{S}_{0}\right)$, an interleaved phyllosilicate grain(IPG)sub-parellel to $\mathrm{S}_{0}-\mathrm{S}_{1}$ ) in the centre (Y5). D. Slate depicting a diagenetic smooth parallel microfabric $\left(\mathrm{S}_{0}\right)$ defined by veinlets of iron oxides and detrital phyllosilicate grains and a discontinuous crenulation cleavage $\left(\mathrm{S}_{1}\right)$ oblique to $\mathrm{S}_{0}(\mathrm{E} 1)$. E. Metadacite showing a granulometric layering sub parallel to a discontinuous metamorphic cleavage $\left(\mathrm{S}_{1}\right)(\mathrm{E} 15)$. F. Metaandesite depicting altered plagioclase and replacement of primary minerals by patches of sulphates of the alunite-jarosite family (see Table 5), Fe oxyhydroxide (white arrow) and fine-grained white mica (yellow arrow) (E17). Scale bar $=0.1 \mathrm{~mm}$. 
coarser bands are mainly composed by anhedral subrounded quartz grains, potassium feldspar and scarce albite. Framboidal pyrite (Fig. 4a), iron oxide, and apatite are common, whereas euhedral rhombic or anhedral sphalerite (Fig. 4b) as well as rutile seldom occur.

\subsubsection{Y1(Cordillera Oriental)}

This slate depict a diagenetic smooth parallel microfabric $\left(\mathrm{S}_{0}\right)$ under the optical microscope (Fig. 3b) and at SEM scale, which is defined by veinlets of iron oxides and detrital phyllosilicate grains, as well as by interleaved phyllosilicate grains, up to $50 \mu \mathrm{m}$ long, broken, with evidences of alteration, and with frayed edges(Fig. 4c). Moreover, a crenulation cleavage $\left(\mathrm{S}_{1}\right)$, defined by elongate chlorite and white mica grains 10 to $25 \mu \mathrm{m}$ long, oriented at a high angle with $\mathrm{S}_{0}$ is also observed (Fig. 4c). Moreover interstitial aggregates of kaolinite 3-15 $\mu \mathrm{m}$ wide, sometimes depicting fan-like morphologies are also common (Fig. 4c, upper right). Kaolinite also partly replaces detrital muscovite laths, showing displacive precipitation along the cleavage planes, leading to "fanning" along the edges of the mica flakes (Fig. 4c, below centre) (De Ros, 1998; Arostegui et al., 2001). Accessory phases include scarce apatite and rutile.
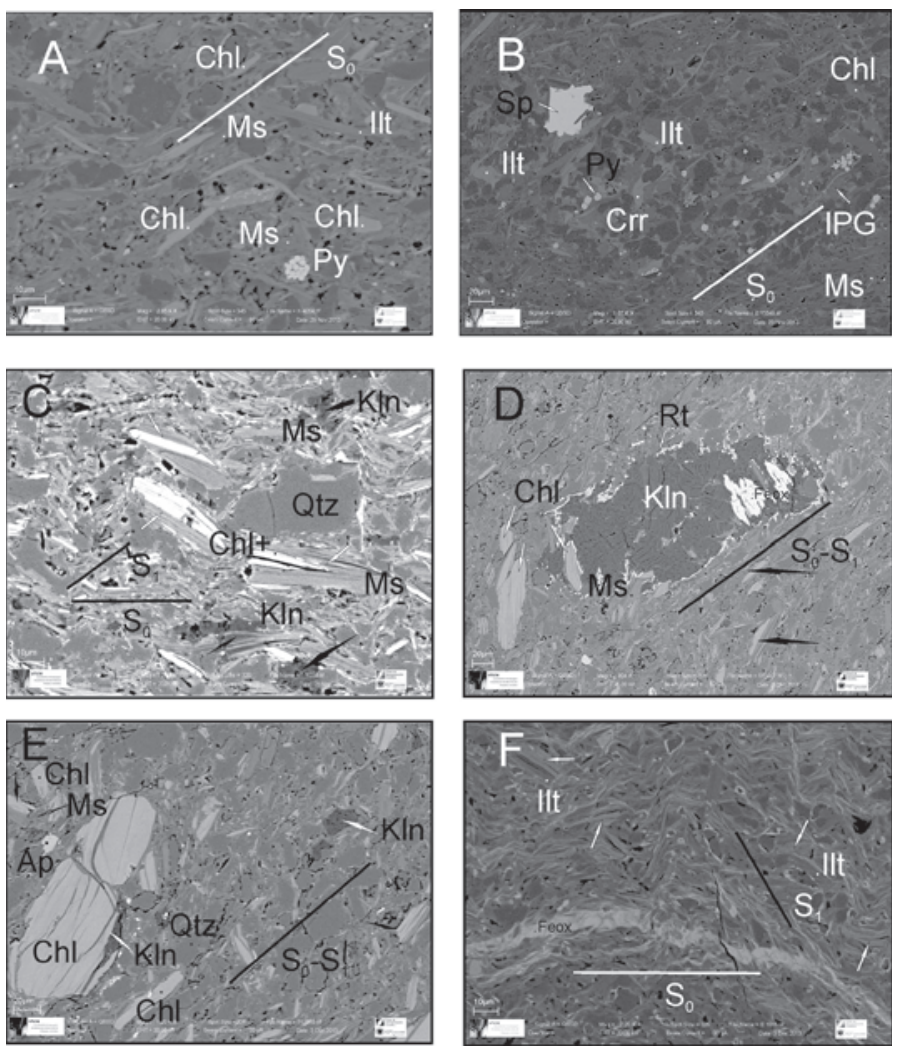

FIG. 4. BSE-SEM images: A. and B. Mudstone N4, showing a diagenetic rough anastomosing sedimentary layering ( $\mathrm{S}_{0}$ ), pyrite, sometimes depicting a framboidal morphology, and sphalerite (Sp, in b); C. Slate depicting a diagenetic smooth parallel foliation $\left(\mathrm{S}_{0}\right)$ and a crenulation cleavage $\left(\mathrm{S}_{1}\right)$, white arrows: interleaved phyllosilicate grains (Chl+impure chlorite), black arrows: kaolinite partly replacing detrital muscovite laths (lower centre) and intersticial aggregates of kaolinite (Y1); D. Slate Y5 depicting a rough anastomosing spaced cleavage $\left(\mathrm{S}_{1}\right)$ parallel to the sedimentary layering $\left(\mathrm{S}_{0}\right)$, in the centre an aggregate of kaolinite composed by multiple fan-like sub aggregates with different orientations, associated with iron oxide and bordered by rutile, IPG grains are also observed (black arrows); E. Chlorite grains sub-parallel or oblique to $\mathrm{S}_{0}-\mathrm{S}_{1}$, interstitial kaolinite occurring as aggregates or along chlorite cleavage planes (white arrows), and IPG (black arrows) in slate Y5; F. Slate E1 depicting a diagenetic smooth parallel foliation $\left(\mathrm{S}_{0}\right)$ defined by veinlets of iron oxides and detrital phyllosilicate grains and a discontinuous crenulation cleavage $\left(\mathrm{S}_{1}\right)$ oblique to $\mathrm{S}_{0}$; the grains resembling chlorite (white arrows) correspond to complex chlorite-bearing mixed-layers according to XRD data and EDS analyses (see Table 5). 


\subsubsection{Y5 (Cordillera Oriental)}

This slate depict a rough anastomosing spaced cleavage $\left(\mathrm{S}_{1}\right)$ parallel to the sedimentary layering $\left(\mathrm{S}_{0}\right)$ under the optical microscope and in BSE images (Figs. 3c and 4d). This slate is more coarse-grained than $\mathrm{Y} 1$ and contains more quartz and albite and less phyllosilicates. Interleaved phyllosilicate grains, up to $60 \mu \mathrm{m}$ long, are frequent (Figs. 3c, 4d, e). Chlorite grains sub-parallel or oblique to $\mathrm{S}_{0}-\mathrm{S}_{1}$ up to $100 \mu \mathrm{m}$ long occur. Subhedral to anhedral quartz grains are abundant. Kaolinite occurs as aggregates $160 \mu \mathrm{m}$ long, $75 \mu \mathrm{m}$ wide composed by multiple fan-like sub aggregates with different orientations, associated with iron oxide and bordered by rutile (Fig. 4d). Moreover, interstitial kaolinite, growing along chlorite cleavage planes (Fig. 4e, white arrows) also occurs. Anhedral apatite, cauliflower rutile and iron oxides occur as accessory phases.

\subsubsection{E1 (Northeastern Puna)}

This slate depict a smooth bedding-parallel microfabric $\left(\mathrm{S}_{0}\right)$ that is defined by veinlets of iron oxides and detrital phyllosilicate grains and a discontinuous crenulation cleavage $\left(\mathrm{S}_{1}\right)$ oblique to $\mathrm{S}_{0}$ that can be observed by optical microscopy and in BSE images (Figs. 3d and 4f). Rotation and bending of primary grains is observed. Anhedral quartz up to $15 \mu \mathrm{m}$ long and albite occur. Apatite, zircon, rutile and monazite occur as accessory phases.

\subsubsection{E4 (Northeastern Puna)}

This slate is mainly composed by anhedral to subhedral quartz grains (up to $30 \mu \mathrm{m}$ ), albite, finegrained white mica, and chlorite. These minerals define a smooth spaced metamorphic cleavage $\left(\mathrm{S}_{1}\right)$ that could be observed under optical microscope and in BSE images. The $\mathrm{S}_{1}$ cleavage is mainly sub parallel to the sedimentary layering $\left(\mathrm{S}_{0}\right)$, defined by veins of iron-titanium oxides, and detrital phyllosilicate grains (Fig. 5a). Most of the mica and chlorite grains are 10 to $35 \mu \mathrm{m}$ long, although chlorite grains up to 100 $\mu \mathrm{m}$ sub parallel or oblique to $\mathrm{S}_{1}$ are also observed. Large chlorite grains sometimes develop pressure shadows associated to the $\mathrm{S}_{1}$ foliation (Fig. $5 b$ ). Some of the grains resembling chlorite (Fig. 5b) correspond to $\mathrm{Chl} / \mathrm{Sm}$ mixed-layers according to EDS analyses (see Table 4). Interleaved phyllosilicate grains composed by chlorite and dioctahedral mica are common. Iron oxides with spheroidal shapes are frequent (Fig. 5a), they seldom occur as aggregates associated with authigenic interleaved chlorite-mica and quartz.

\subsubsection{E15 (Puna)}

Afanitic fine-grained metadacite, mainly composed by quartz and albite, with subordinate muscovite and kaolinite. Phyllosilicate flakes and elongated quartz grains define a discontinuous metamorphic cleavage $\left(\mathrm{S}_{1}\right)$ that could be observed under the optical microscope (Fig. 3e). Quartz as well as albite crystals frequently exhibit embayments and skeletal forms and serrated contacts (Fig. 5c). Kaolinite occurs as fibrous irregular aggregates filling voids, replacing skeletal tabular grains; and partly replacing muscovite laths, showing displacive precipitation along the cleavage planes (Fig. 5c). Anhedral titanium oxide, monazite, apatite, and euhedral zircon are present as accessory minerals.

\subsubsection{E17 (Puna)}

Fine grained metaandesite, depicting abundant sub millimeter vesicles, and red-brown and yellow to orange veinlets in hand specimen. Under the optical microscope it shows a porphyric texture, and is mainly composed by phenocrysts of albitized plagioclase and muscovite immersed in a groundmass composed by albite, red iron oxide and yellow-brown to orange iron oxyhydroxide, ilmenite and secondary fine-grained white mica (Fig. 3f). Plagioclase is greatly replaced by fine-grained white mica (Fig. 3f, white arrows), whereas mafic minerals are strongly altered. Primary minerals are also replaced by secondary mixed-layered phyllosilicates forming radial aggregates or veinlets and patches of euhedral to anhedral sulfates of the alunite-jarosite family (Fig. 3f). Titanite, scarce quartz, and accessory zircon also occur.

At SEM scale prismatic phenocrysts of albite up to $0.9 \mu \mathrm{m}$ in length frequently depict dissolution voids, embayments filled with mixed-layered phyllosilicates, replacement by fine-grained white mica in the centre, on edges or filling fractures (Fig. 5d). Moreover, albite phenocrysts close to amoeboidal titanium oxide depict inclusions of this mineral. All in all, these features suggest alteration by hydrothermal fluids. In the groundmass, albite occurs as microlites up to $0.25 \mu \mathrm{m}$ long. Muscovite occurs as subhedral to euhedral laths, $\sim 25-150 \mathrm{~mm}$ long and 6-40 $\mu \mathrm{m}$ wide, some crystals depicting skeletal forms and zonation could be volcanic in origin (Fig. 5e), in other cases, this mineral occurs 

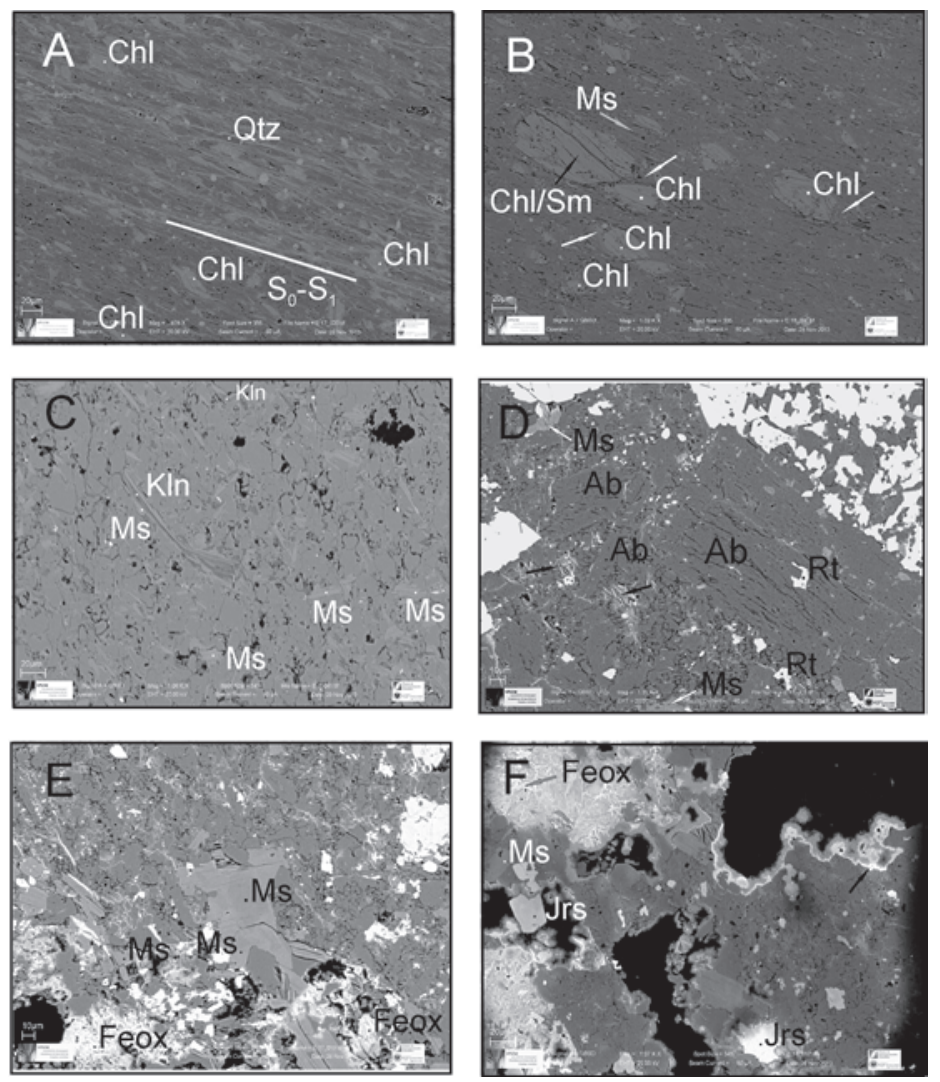

FIG. 5. BSE-SEM images: A. Slate showing a smooth spaced metamorphic cleavage $\left(\mathrm{S}_{1}\right)$ defined by preferred orientation of chlorite and mica flakes, it is mainly sub parallel to the sedimentary layering $\left(\mathrm{S}_{0}\right)$ that is defined by veins of iron-titanium oxides and detrital phyllosilicate grains. Tiny spheroidal grains of iron oxides can also be observed(E4); B. Large chlorite grains depicting pressure shadows (white arrows) associated to the $\mathrm{S}_{1}$ foliation in slateE4, some of the grains resembling chlorite (black arrow) correspond to Chl/Sm mixed-layers according to EDS analyses (see Table 4); C. Fine grained metadacite composed by quartz and albite crystals, frequently exhibiting embayments and skeletal forms and serrated contacts, kaolinite replacing muscovite laths could also be observed (E15); D. Prismatic phenocrysts of albite frequently depicting dissolution voids and embayments filled with fibrous mixed-layered phyllosilicates (black arrows) in metaandesite E17, an albite phenocrysts close to amoeboidal titanium oxide depicting inclusions of this mineral is also shown; E. Muscovite depicting skeletal forms and zonation, probably volcanic in origin in metaandesite E 17; F. Sulfates of the alunite-jarosite family filling amygdules, rimming cavities, forming subhedral crystals and amoeboidal patches in metaandesite E17, in the cavity shown in the upper right sulfates are rimming impure iron oxides (black arrow).

associated to veinlets indicating a secondary origin. Mixed-layered phyllosilicates occurs in fibers $\sim 1-2$ $\mu \mathrm{m}$ wide forming radial aggregates or veinlets, indicating a hydrothermal origin (Fig. 5e). Scarce anhedral quartz, up to $100 \mu \mathrm{m}$ wide, exhibiting embayments occurs associated with the veinlets of mixed-layers, thus it is probably secondary in origin. Sulfates of the alunite-jarosite family, mainly jarosite showing some $\mathrm{Na}^{+}$by $\mathrm{K}^{+}, \mathrm{P}$ by $\mathrm{S}$ and minor $\mathrm{Al}^{+3}$ by $\mathrm{Fe}^{+3}$ substitution, fill amygdules, rimed cavities, form amoeboidal patches and veinlets (Fig. 5f), and also subhedral crystals up to $0.1 \mathrm{~mm}$ in size (Fig. 3e).
Sulfates frequently occur associated (or replaced) with patches of iron oxides $(>150 \mu \mathrm{m})$, whereas in cavities and amygdules they are frequently rimming impure iron oxides (Fig. 5f).

\subsection{Composition of Phyllosilicates}

\subsubsection{Dioctahedral Micas}

Table 2 shows representative analyses of dioctahedral micas. Except in the metaandesite E17, which mainly contain muscovite of volcanic origin, analyses show a large variation in the $\mathrm{Si}, \mathrm{Fe}+\mathrm{Mg}$ and interlayer 
TABLE 2. SELECTED EDS ANALYSIS OF DIOCTAHEDRAL MICAS.

\begin{tabular}{|c|c|c|c|c|c|c|c|c|c|c|c|c|c|c|c|c|c|c|c|}
\hline \multirow{2}{*}{ Element } & \multicolumn{19}{|c|}{ E1 } \\
\hline & $2-2$ & $2-3$ & $2-4$ & $2-8$ & $3-3$ & $3-4$ & $3-7$ & 4-3 & $4-5$ & $5-2$ & $5-6$ & $5-8$ & 6-2 & $6-3$ & $7-5$ & $7-7$ & $7-9$ & $8-4$ & $8-6$ \\
\hline Si & 3.14 & 3.23 & 3.14 & 3.20 & 3.44 & 3.07 & 3.28 & 3.05 & 3.01 & 3.05 & 3.43 & 3.10 & 3.36 & 3.42 & 3.10 & 3.32 & 3.09 & 3.04 & 3.13 \\
\hline $\mathbf{A l}^{\mathrm{IV}}$ & 0.86 & 0.77 & 0.86 & 0.80 & 0.56 & 0.93 & 0.72 & 0.95 & 0.99 & 0.95 & 0.57 & 0.90 & 0.64 & 0.58 & 0.90 & 0.68 & 0.91 & 0.96 & 0.87 \\
\hline $\mathbf{A l}^{\mathrm{VI}}$ & 1.82 & 1.66 & 1.52 & 1.61 & 1.35 & 1.81 & 1.52 & 1.72 & 1.74 & 1.76 & 1.61 & 1.87 & 1.80 & 1.64 & 1.80 & 1.66 & 1.77 & 1.85 & 1.90 \\
\hline $\mathrm{Fe}$ & 0.11 & 0.23 & 0.34 & 0.27 & 0.36 & 0.19 & 0.28 & 0.25 & 0.22 & 0.24 & 0.32 & 0.09 & 0.15 & 0.24 & 0.13 & 0.18 & 0.12 & 0.12 & 0.06 \\
\hline Mg & 0.13 & 0.18 & 0.18 & 0.19 & 0.33 & 0.06 & 0.22 & 0.11 & 0.13 & 0.07 & 0.06 & 0.04 & 0.06 & 0.12 & 0.09 & 0.21 & 0.07 & 0.06 & 0.05 \\
\hline Mn & 0.00 & 0.00 & 0.00 & 0.00 & 0.00 & 0.00 & 0.00 & 0.00 & 0.00 & 0.00 & 0.00 & 0.00 & 0.00 & 0.00 & 0.00 & 0.00 & 0.00 & 0.00 & 0.00 \\
\hline $\mathbf{T i}$ & 0.00 & 0.00 & 0.00 & 0.00 & 0.00 & 0.00 & 0.00 & 0.00 & 0.00 & 0.00 & 0.00 & 0.00 & 0.00 & 0.00 & 0.02 & 0.00 & 0.05 & 0.00 & 0.00 \\
\hline$\sum$ oct. & 2.05 & 2.06 & 2.05 & 2.07 & 2.04 & 2.06 & 2.02 & 2.09 & 2.08 & 2.07 & 1.99 & 2.01 & 2.01 & 2.00 & 2.05 & 2.05 & 2.01 & 2.03 & 2.01 \\
\hline $\mathbf{K}$ & 0.83 & 0.76 & 0.90 & 0.78 & 0.78 & 0.81 & 0.88 & 0.80 & 0.78 & 0.82 & 0.67 & 0.86 & 0.67 & 0.69 & 0.76 & 0.75 & 0.83 & 0.79 & 0.90 \\
\hline $\mathrm{Na}$ & 0.00 & 0.00 & 0.00 & 0.00 & 0.00 & 0.00 & 0.00 & 0.00 & 0.08 & 0.00 & 0.00 & 0.06 & 0.00 & 0.00 & 0.06 & 0.00 & 0.09 & 0.14 & 0.00 \\
\hline $\mathrm{Ca}$ & 0.00 & 0.00 & 0.00 & 0.00 & 0.00 & 0.00 & 0.00 & 0.00 & 0.00 & 0.00 & 0.00 & 0.00 & 0.00 & 0.00 & 0.00 & 0.00 & 0.00 & 0.00 & 0.00 \\
\hline$\Sigma$ int. & 0.83 & 0.76 & 0.90 & 0.78 & 0.78 & 0.81 & 0.88 & 0.80 & 0.86 & 0.82 & 0.67 & 0.92 & 0.67 & 0.69 & 0.82 & 0.75 & 0.92 & 0.93 & 0.90 \\
\hline
\end{tabular}

\begin{tabular}{|c|c|c|c|c|c|c|c|c|c|c|c|c|c|c|c|c|c|c|}
\hline \multirow{2}{*}{ Element } & \multicolumn{10}{|c|}{ E1 } & \multicolumn{8}{|c|}{ E4 } \\
\hline & 8-8 & $9-3$ & $9-4$ & $9-5$ & $9-6$ & $10-4$ & $10-5$ & $10-6$ & $10-7$ & $10-10$ & $4-5$ & $5-6$ & $5-7$ & $7-7$ & $8-6$ & 8-9 & $10-6$ & $10-7$ \\
\hline $\mathbf{S i}$ & 3.27 & 3.30 & 3.06 & 3.05 & 3.16 & 3.05 & 3.07 & 3.26 & 3.07 & 3.13 & 3.32 & 3.16 & 3.00 & 3.02 & 3.30 & 3.15 & 3.27 & 3.15 \\
\hline $\mathrm{Al}^{\mathrm{IV}}$ & 0.73 & 0.70 & 0.94 & 0.95 & 0.84 & 0.95 & 0.93 & 0.74 & 0.93 & 0.87 & 0.68 & 0.84 & 1.00 & 0.98 & 0.70 & 0.85 & 0.73 & 0.85 \\
\hline $\mathrm{Al}^{\mathrm{VI}}$ & 1.71 & 1.72 & 1.87 & 1.86 & 1.72 & 1.87 & 1.79 & 1.68 & 1.81 & 1.67 & 1.50 & 1.65 & 1.99 & 1.96 & 1.38 & 1.82 & 1.58 & 1.77 \\
\hline $\mathrm{Fe}$ & 0.15 & 0.12 & 0.08 & 0.11 & 0.21 & 0.06 & 0.15 & 0.15 & 0.13 & 0.16 & 0.28 & 0.19 & 0.02 & 0.04 & 0.35 & 0.13 & 0.20 & 0.09 \\
\hline Mg & 0.18 & 0.14 & 0.11 & 0.08 & 0.16 & 0.08 & 0.12 & 0.19 & 0.10 & 0.19 & 0.25 & 0.20 & 0.04 & 0.06 & 0.27 & 0.09 & 0.27 & 0.15 \\
\hline Mn & 0.00 & 0.00 & 0.00 & 0.00 & 0.00 & 0.00 & 0.00 & 0.00 & 0.00 & 0.00 & 0.00 & 0.00 & 0.00 & 0.00 & 0.00 & 0.00 & 0.00 & 0.00 \\
\hline Ti & 0.03 & 0.02 & 0.00 & 0.00 & 0.00 & 0.03 & 0.00 & 0.00 & 0.00 & 0.03 & 0.00 & 0.00 & 0.00 & 0.00 & 0.00 & 0.00 & 0.00 & 0.00 \\
\hline$\sum$ oct. & 2.06 & 2.01 & 2.06 & 2.05 & 2.09 & 2.04 & 2.07 & 2.02 & 2.04 & 2.04 & 2.03 & 2.04 & 2.05 & 2.05 & 2.01 & 2.05 & 2.06 & 2.01 \\
\hline $\mathbf{K}$ & 0.71 & 0.78 & 0.88 & 0.87 & 0.73 & 0.89 & 0.73 & 0.88 & 0.93 & 0.92 & 0.83 & 0.85 & 0.82 & 0.77 & 0.95 & 0.68 & 0.84 & 0.91 \\
\hline $\mathrm{Na}$ & 0.00 & 0.00 & 0.00 & 0.00 & 0.00 & 0.00 & 0.13 & 0.00 & 0.00 & 0.00 & 0.00 & 0.06 & 0.07 & 0.11 & 0.00 & 0.12 & 0.00 & 0.06 \\
\hline $\mathrm{Ca}$ & 0.00 & 0.00 & 0.00 & 0.00 & 0.00 & 0.00 & 0.00 & 0.00 & 0.00 & 0.00 & 0.00 & 0.00 & 0.00 & 0.00 & 0.00 & 0.00 & 0.00 & 0.00 \\
\hline$\Sigma$ int. & 0.71 & 0.78 & 0.88 & 0.87 & 0.73 & 0.89 & 0.86 & 0.88 & 0.93 & 0.92 & 0.83 & 0.91 & 0.88 & 0.87 & 0.95 & 0.81 & 0.84 & 0.97 \\
\hline
\end{tabular}

1: matrix mica; 2: detrital mica; 3: darker zone. 
Table 2 continued.

\begin{tabular}{|c|c|c|c|c|c|c|c|c|c|c|c|c|c|c|c|c|c|c|c|}
\hline \multirow{2}{*}{ Element } & \multicolumn{19}{|c|}{ E 15} \\
\hline & $2-1$ & $2-3$ & $2-4$ & $2-6$ & $2-7$ & $3-5$ & 4-3 & $4-4$ & $5-1$ & $5-2$ & $5-3$ & $5-4$ & $5-5$ & $5-7$ & 6-1 & $6-2$ & $6-3$ & $6-6$ & $6-7$ \\
\hline Si & 3.16 & 3.07 & 3.21 & 3.29 & 3.18 & 3.20 & 3.32 & 3.15 & 3.19 & 3.40 & 3.16 & 3.13 & 3.29 & 3.36 & 3.23 & 3.14 & 3.17 & 3.37 & 3.12 \\
\hline $\mathrm{Al}^{\mathrm{IV}}$ & 0.84 & 0.93 & 0.79 & 0.71 & 0.82 & 0.80 & 0.68 & 0.85 & 0.81 & 0.60 & 0.84 & 0.87 & 0.71 & 0.64 & 0.77 & 0.86 & 0.83 & 0.63 & 0.88 \\
\hline $\mathbf{A l}^{\mathrm{VI}}$ & 1.82 & 1.75 & 1.66 & 1.62 & 1.56 & 1.84 & 1.53 & 1.82 & 1.82 & 1.65 & 1.81 & 1.80 & 1.83 & 1.79 & 1.60 & 1.73 & 1.72 & 1.46 & 1.84 \\
\hline $\mathrm{Fe}$ & 0.09 & 0.15 & 0.14 & 0.18 & 0.22 & 0.03 & 0.24 & 0.08 & 0.07 & 0.15 & 0.10 & 0.10 & 0.07 & 0.08 & 0.20 & 0.18 & 0.12 & 0.27 & 0.08 \\
\hline Mg & 0.10 & 0.11 & 0.18 & 0.15 & 0.22 & 0.13 & 0.26 & 0.15 & 0.10 & 0.22 & 0.10 & 0.11 & 0.10 & 0.11 & 0.23 & 0.12 & 0.18 & 0.30 & 0.11 \\
\hline $\mathbf{T i}$ & 0.00 & 0.02 & 0.02 & 0.03 & 0.03 & 0.03 & 0.00 & 0.00 & 0.03 & 0.00 & 0.00 & 0.00 & 0.00 & 0.00 & 0.00 & 0.00 & 0.00 & 0.00 & 0.00 \\
\hline$\sum$ oct. & 2.01 & 2.03 & 2.00 & 1.99 & 2.03 & 2.03 & 2.03 & 2.04 & 2.01 & 2.01 & 2.02 & 2.01 & 2.00 & 1.99 & 2.02 & 2.03 & 2.02 & 2.02 & 2.03 \\
\hline K & 0.91 & 0.93 & 0.95 & 0.88 & 0.92 & 0.71 & 0.86 & 0.88 & 0.85 & 0.79 & 0.89 & 0.89 & 0.81 & 0.79 & 0.93 & 0.88 & 0.94 & 0.85 & 0.91 \\
\hline $\mathrm{Na}$ & 0.00 & 0.00 & 0.00 & 0.00 & 0.00 & 0.08 & 0.00 & 0.00 & 0.00 & 0.00 & 0.00 & 0.05 & 0.00 & 0.00 & 0.00 & 0.00 & 0.00 & 0.00 & 0.00 \\
\hline $\mathrm{Ca}$ & 0.00 & 0.00 & 0.00 & 0.00 & 0.00 & 0.00 & 0.00 & 0.00 & 0.00 & 0.00 & 0.00 & 0.00 & 0.00 & 0.00 & 0.00 & 0.00 & 0.00 & 0.00 & 0.00 \\
\hline$\Sigma$ int. & 0.91 & 0.93 & 0.95 & 0.88 & 0.92 & 0.80 & 0.86 & 0.88 & 0.85 & 0.79 & 0.89 & 0.94 & 0.81 & 0.79 & 0.93 & 0.88 & 0.94 & 0.85 & 0.91 \\
\hline
\end{tabular}

\begin{tabular}{|c|c|c|c|c|c|c|c|c|c|c|c|c|c|c|c|c|c|c|c|}
\hline \multirow{2}{*}{ Element } & \multicolumn{5}{|c|}{ E15 } & \multicolumn{14}{|c|}{ E 17} \\
\hline & $7-3$ & $7-4$ & $7-6$ & $8-2$ & $8-4$ & $5-6$ & $5-10$ & $6-3$ & $7-1$ & $7-4$ & $8-2$ & $10-1$ & $11-6$ & $12-10$ & 13-7 & $14-8$ & $15-1$ & $15-3$ & $16-2$ \\
\hline $\mathbf{S i}$ & 3.10 & 3.15 & 3.24 & 3.32 & 3.34 & 3.11 & 3.15 & 3.07 & 3.14 & 3.10 & 3.09 & 3.07 & 3.08 & 3.10 & 3.11 & 3.14 & 3.10 & 3.08 & 3.15 \\
\hline $\mathrm{Al}^{\mathrm{IV}}$ & 0.90 & 0.85 & 0.76 & 0.68 & 0.66 & 0.89 & 0.85 & 0.93 & 0.86 & 0.90 & 0.91 & 0.93 & 0.92 & 0.90 & 0.89 & 0.86 & 0.90 & 0.92 & 0.85 \\
\hline $\mathbf{A l}^{\mathrm{VI}}$ & 1.78 & 1.78 & 1.64 & 1.78 & 1.76 & 1.78 & 1.76 & 1.79 & 1.82 & 1.70 & 1.79 & 1.78 & 1.83 & 1.78 & 1.67 & 1.79 & 1.80 & 1.74 & 1.69 \\
\hline $\mathbf{F e}$ & 0.11 & 0.12 & 0.14 & 0.09 & 0.11 & 0.07 & 0.09 & 0.09 & 0.08 & 0.13 & 0.09 & 0.08 & 0.07 & 0.08 & 0.10 & 0.08 & 0.08 & 0.09 & 0.13 \\
\hline Mg & 0.12 & 0.10 & 0.22 & 0.13 & 0.12 & 0.16 & 0.17 & 0.15 & 0.15 & 0.19 & 0.15 & 0.14 & 0.13 & 0.19 & 0.20 & 0.15 & 0.16 & 0.18 & 0.19 \\
\hline Ti & 0.03 & 0.02 & 0.03 & 0.00 & 0.00 & 0.03 & 0.02 & 0.02 & 0.00 & 0.04 & 0.00 & 0.04 & 0.03 & 0.02 & 0.04 & 0.00 & 0.03 & 0.04 & 0.03 \\
\hline$\sum$ oct. & 2.03 & 2.02 & 2.03 & 2.01 & 2.00 & 2.04 & 2.04 & 2.06 & 2.04 & 2.06 & 2.04 & 2.04 & 2.05 & 2.06 & 2.01 & 2.02 & 2.07 & 2.04 & 2.04 \\
\hline $\mathbf{K}$ & 0.90 & 0.78 & 0.86 & 0.80 & 0.78 & 0.87 & 0.88 & 0.87 & 0.88 & 0.87 & 0.90 & 0.86 & 0.86 & 0.87 & 0.88 & 0.84 & 0.83 & 0.84 & 0.88 \\
\hline $\mathrm{Na}$ & 0.00 & 0.08 & 0.00 & 0.00 & 0.00 & 0.05 & 0.00 & 0.00 & 0.00 & 0.00 & 0.05 & 0.00 & 0.00 & 0.00 & 0.00 & 0.07 & 0.00 & 0.04 & 0.00 \\
\hline $\mathrm{Ca}$ & 0.00 & 0.00 & 0.00 & 0.00 & 0.00 & 0.00 & 0.00 & 0.00 & 0.00 & 0.00 & 0.00 & 0.02 & 0.00 & 0.00 & 0.06 & 0.02 & 0.00 & 0.03 & 0.00 \\
\hline$\Sigma$ int. & 0.90 & 0.87 & 0.86 & 0.80 & 0.78 & 0.91 & 0.88 & 0.87 & 0.88 & 0.87 & 0.95 & 0.91 & 0.86 & 0.87 & 1.00 & 0.95 & 0.83 & 0.94 & 0.88 \\
\hline
\end{tabular}




\begin{tabular}{|c|c|c|c|c|c|c|c|c|c|c|c|c|c|c|c|c|c|c|c|}
\hline \multirow{2}{*}{ Element } & \multicolumn{5}{|c|}{ E17 } & \multicolumn{14}{|c|}{ N4 } \\
\hline & $17-1$ & $19-2$ & $19-3$ & $19-4$ & $19-7$ & $1-5$ & $3-5$ & 3-7 & 4-4 & $4-5^{1}$ & 4-6 & 5-2 & 5-8 & $5-10$ & 6-6 & 6-7 & $7-6$ & $7-7$ & $7-9$ \\
\hline $\mathbf{S i}$ & 3.01 & 3.06 & 3.20 & 3.10 & 3.09 & 3.45 & 3.33 & 3.29 & 3.23 & 3.30 & 3.41 & 3.27 & 3.41 & 3.31 & 3.14 & 3.30 & 3.33 & 3.17 & 3.22 \\
\hline $\mathrm{Al}^{\mathrm{IV}}$ & 0.99 & 0.94 & 0.80 & 0.90 & 0.91 & 0.55 & 0.67 & 0.71 & 0.77 & 0.70 & 0.59 & 0.73 & 0.59 & 0.69 & 0.86 & 0.70 & 0.67 & 0.83 & 0.78 \\
\hline $\mathbf{A l}^{\mathrm{VI}}$ & 1.81 & 1.80 & 1.76 & 1.74 & 1.73 & 1.58 & 1.68 & 1.54 & 1.55 & 1.59 & 1.70 & 1.70 & 1.61 & 1.41 & 1.58 & 1.68 & 1.68 & 1.78 & 1.53 \\
\hline $\mathrm{Fe}$ & 0.09 & 0.09 & 0.08 & 0.08 & 0.11 & 0.20 & 0.08 & 0.30 & 0.21 & 0.16 & 0.11 & 0.14 & 0.18 & 0.30 & 0.29 & 0.16 & 0.15 & 0.10 & 0.24 \\
\hline Mg & 0.15 & 0.14 & 0.19 & 0.15 & 0.17 & 0.21 & 0.28 & 0.24 & 0.32 & 0.19 & 0.18 & 0.18 & 0.18 & 0.34 & 0.15 & 0.18 & 0.18 & 0.11 & 0.24 \\
\hline $\mathbf{T i}$ & 0.03 & 0.04 & 0.00 & 0.05 & 0.05 & 0.00 & 0.00 & 0.00 & 0.00 & 0.08 & 0.00 & 0.00 & 0.03 & 0.03 & 0.00 & 0.00 & 0.00 & 0.00 & 0.03 \\
\hline$\sum$ oct. & 2.07 & 2.07 & 2.03 & 2.02 & 2.05 & 2.00 & 2.04 & 2.08 & 2.07 & 2.01 & 1.99 & 2.02 & 1.99 & 2.07 & 2.02 & 2.02 & 2.00 & 2.00 & 2.04 \\
\hline $\mathbf{K}$ & 0.89 & 0.84 & 0.88 & 0.88 & 0.89 & 0.49 & 0.82 & 0.70 & 0.86 & 0.79 & 0.80 & 0.86 & 0.70 & 0.71 & 0.94 & 0.83 & 0.83 & 0.88 & 0.83 \\
\hline $\mathrm{Na}$ & 0.00 & 0.00 & 0.00 & 0.00 & 0.00 & 0.28 & 0.00 & 0.00 & 0.00 & 0.00 & 0.00 & 0.00 & 0.07 & 0.08 & 0.00 & 0.00 & 0.00 & 0.07 & 0.05 \\
\hline $\mathrm{Ca}$ & 0.00 & 0.00 & 0.00 & 0.03 & 0.00 & 0.00 & 0.00 & 0.00 & 0.00 & 0.00 & 0.00 & 0.00 & 0.00 & 0.00 & 0.00 & 0.00 & 0.00 & 0.00 & 0.00 \\
\hline$\Sigma$ int. & 0.89 & 0.84 & 0.88 & 0.94 & 0.89 & 0.77 & 0.82 & 0.70 & 0.86 & 0.79 & 0.80 & 0.86 & 0.76 & 0.79 & 0.94 & 0.83 & 0.83 & 0.95 & 0.88 \\
\hline
\end{tabular}

\begin{tabular}{|c|c|c|c|c|c|c|c|c|c|c|c|c|c|c|c|c|c|c|c|}
\hline \multirow{2}{*}{ Element } & \multicolumn{11}{|c|}{ N4 } & \multicolumn{8}{|c|}{ Y1 } \\
\hline & $7-11$ & $8-6$ & $8-8$ & $9-3$ & $10-6$ & $10-11$ & $11-4$ & $11-5$ & $11-6$ & $11-7$ & $11-8$ & $2-6^{2}$ & $2-10$ & $3-3$ & 3-6 & 4-3 & $5-1$ & $5-3$ & $5-5$ \\
\hline Si & 3.23 & 3.17 & 3.07 & 3.25 & 3.15 & 3.09 & 3.37 & 3.17 & 3.20 & 3.22 & 3.31 & 3.10 & 3.16 & 3.14 & 3.16 & 3.32 & 3.08 & 3.01 & 3.20 \\
\hline $\mathrm{Al}^{\mathrm{IV}}$ & 0.77 & 0.83 & 0.93 & 0.75 & 0.85 & 0.91 & 0.63 & 0.83 & 0.80 & 0.78 & 0.69 & 0.90 & 0.84 & 0.86 & 0.84 & 0.68 & 0.92 & 0.99 & 0.80 \\
\hline $\mathbf{A l}^{\mathrm{VI}}$ & 1.72 & 1.52 & 1.73 & 1.45 & 1.64 & 1.85 & 1.51 & 1.76 & 1.61 & 1.61 & 1.74 & 1.75 & 1.80 & 1.62 & 1.79 & 1.49 & 1.85 & 1.94 & 1.71 \\
\hline $\mathrm{Fe}$ & 0.19 & 0.24 & 0.15 & 0.31 & 0.17 & 0.07 & 0.21 & 0.09 & 0.26 & 0.17 & 0.10 & 0.11 & 0.10 & 0.26 & 0.11 & 0.27 & 0.07 & 0.05 & 0.11 \\
\hline Mg & 0.11 & 0.27 & 0.13 & 0.22 & 0.21 & 0.09 & 0.24 & 0.13 & 0.19 & 0.22 & 0.20 & 0.11 & 0.10 & 0.23 & 0.12 & 0.21 & 0.12 & 0.05 & 0.15 \\
\hline Ti & 0.00 & 0.03 & 0.02 & 0.03 & 0.03 & 0.00 & 0.04 & 0.03 & 0.00 & 0.03 & 0.00 & 0.04 & 0.00 & 0.00 & 0.00 & 0.03 & 0.00 & 0.00 & 0.03 \\
\hline$\sum$ oct. & 2.02 & 2.07 & 2.03 & 2.02 & 2.05 & 2.01 & 1.99 & 2.01 & 2.06 & 2.04 & 2.05 & 2.00 & 2.00 & 2.10 & 2.01 & 2.00 & 2.03 & 2.05 & 2.00 \\
\hline $\mathbf{K}$ & 0.78 & 0.87 & 0.90 & 0.90 & 0.83 & 0.80 & 0.80 & 0.81 & 0.81 & 0.85 & 0.71 & 0.89 & 0.83 & 0.78 & 0.92 & 0.85 & 0.85 & 0.82 & 0.85 \\
\hline $\mathrm{Na}$ & 0.05 & 0.00 & 0.06 & 0.00 & 0.05 & 0.16 & 0.06 & 0.09 & 0.00 & 0.00 & 0.00 & 0.07 & 0.10 & 0.00 & 0.00 & 0.00 & 0.09 & 0.07 & 0.07 \\
\hline $\mathrm{Ca}$ & 0.00 & 0.00 & 0.00 & 0.00 & 0.00 & 0.00 & 0.00 & 0.00 & 0.00 & 0.00 & 0.02 & 0.00 & 0.00 & 0.00 & 0.00 & 0.00 & 0.00 & 0.00 & 0.00 \\
\hline$\Sigma$ int. & 0.83 & 0.87 & 0.96 & 0.90 & 0.88 & 0.96 & 0.86 & 0.90 & 0.81 & 0.85 & 0.75 & 0.96 & 0.94 & 0.78 & 0.92 & 0.85 & 0.95 & 0.90 & 0.92 \\
\hline
\end{tabular}




\begin{tabular}{|c|c|c|c|c|c|c|c|c|c|c|c|c|c|c|c|c|c|c|c|}
\hline \multirow{2}{*}{ Element } & \multicolumn{14}{|c|}{ Y1 } & \multicolumn{5}{|c|}{ Y5 } \\
\hline & $5-6$ & $6-2$ & $6-3^{3}$ & $6-5$ & 6-6 & $6-7$ & $7-1$ & $7-2$ & $7-3$ & $7-5$ & $8-2$ & $8-3$ & $8-4$ & $8-5$ & $1-3$ & $1-5$ & $2-7$ & $2-8$ & $2-9$ \\
\hline $\mathbf{S i}$ & 3.18 & 3.25 & 3.11 & 3.05 & 3.04 & 3.26 & 3.09 & 3.14 & 3.09 & 3.28 & 3.11 & 3.14 & 3.02 & 3.06 & 3.04 & 3.10 & 3.02 & 3.25 & 3.02 \\
\hline $\mathrm{Al}^{\mathrm{IV}}$ & 0.82 & 0.75 & 0.89 & 0.95 & 0.96 & 0.74 & 0.91 & 0.86 & 0.91 & 0.72 & 0.89 & 0.86 & 0.98 & 0.94 & 0.96 & 0.90 & 0.98 & 0.75 & 0.98 \\
\hline $\mathbf{A I}^{\mathrm{VI}}$ & 1.65 & 1.48 & 1.91 & 1.73 & 1.83 & 1.60 & 1.80 & 1.79 & 1.93 & 1.79 & 1.88 & 1.73 & 1.84 & 1.90 & 1.96 & 1.81 & 1.72 & 1.74 & 1.91 \\
\hline $\mathrm{Fe}$ & 0.21 & 0.28 & 0.07 & 0.23 & 0.12 & 0.20 & 0.13 & 0.15 & 0.06 & 0.14 & 0.05 & 0.15 & 0.12 & 0.04 & 0.00 & 0.10 & 0.16 & 0.15 & 0.07 \\
\hline Mg & 0.18 & 0.25 & 0.06 & 0.07 & 0.07 & 0.20 & 0.13 & 0.09 & 0.06 & 0.09 & 0.07 & 0.16 & 0.08 & 0.06 & 0.06 & 0.10 & 0.11 & 0.14 & 0.06 \\
\hline $\mathbf{T i}$ & 0.00 & 0.00 & 0.00 & 0.02 & 0.00 & 0.00 & 0.00 & 0.00 & 0.00 & 0.00 & 0.00 & 0.00 & 0.00 & 0.03 & 0.00 & 0.00 & 0.03 & 0.00 & 0.02 \\
\hline$\sum$ oct. & 2.04 & 2.01 & 2.04 & 2.06 & 2.03 & 2.01 & 2.06 & 2.03 & 2.05 & 2.01 & 2.01 & 2.04 & 2.04 & 2.03 & 2.02 & 2.00 & 2.02 & 2.04 & 2.05 \\
\hline $\mathbf{K}$ & 0.89 & 0.97 & 0.82 & 0.83 & 0.88 & 0.92 & 0.85 & 0.86 & 0.83 & 0.71 & 0.89 & 0.89 & 0.84 & 0.83 & 0.87 & 0.89 & 0.85 & 0.77 & 0.79 \\
\hline $\mathrm{Na}$ & 0.00 & 0.00 & 0.00 & 0.00 & 0.07 & 0.00 & 0.00 & 0.00 & 0.00 & 0.07 & 0.06 & 0.00 & 0.10 & 0.06 & 0.10 & 0.10 & 0.15 & 0.00 & 0.06 \\
\hline $\mathrm{Ca}$ & 0.00 & 0.00 & 0.00 & 0.00 & 0.00 & 0.00 & 0.00 & 0.00 & 0.00 & 0.00 & 0.00 & 0.00 & 0.00 & 0.00 & 0.00 & 0.00 & 0.00 & 0.00 & 0.00 \\
\hline$\Sigma$ int. & 0.89 & 0.97 & 0.82 & 0.83 & 0.95 & 0.92 & 0.85 & 0.86 & 0.83 & 0.78 & 0.95 & 0.89 & 0.93 & 0.90 & 0.97 & 0.99 & 1.00 & 0.77 & 0.85 \\
\hline
\end{tabular}

\begin{tabular}{|c|c|c|c|c|c|c|c|c|c|c|c|c|c|c|c|c|c|c|}
\hline \multirow{2}{*}{ Element } & \multicolumn{18}{|c|}{ Y5 } \\
\hline & $3-4$ & 3-8 & 4-5 & $4-7$ & $4-8$ & 4-9 & $5-5$ & $5-7$ & 6-2 & $6-4$ & $6-12$ & $7-4$ & $7-8$ & $7-9$ & $7-10$ & $8-7$ & $10-4$ & $10-6$ \\
\hline $\mathbf{S i}$ & 3.13 & 3.35 & 3.23 & 3.11 & 3.23 & 3.04 & 3.01 & 3.05 & 3.05 & 3.32 & 3.29 & 3.08 & 3.39 & 3.12 & 3.20 & 3.04 & 3.05 & 3.14 \\
\hline $\mathrm{Al}^{\mathrm{IV}}$ & 0.87 & 0.65 & 0.77 & 0.89 & 0.77 & 0.96 & 0.99 & 0.95 & 0.95 & 0.68 & 0.71 & 0.92 & 0.61 & 0.88 & 0.80 & 0.96 & 0.95 & 0.86 \\
\hline $\mathbf{A l}^{\mathrm{VI}}$ & 1.73 & 1.64 & 1.67 & 1.75 & 1.61 & 1.79 & 1.81 & 1.85 & 1.93 & 1.69 & 1.53 & 1.64 & 1.55 & 1.62 & 1.60 & 1.94 & 1.90 & 1.70 \\
\hline $\mathbf{F e}$ & 0.16 & 0.14 & 0.15 & 0.14 & 0.21 & 0.16 & 0.07 & 0.13 & 0.05 & 0.12 & 0.24 & 0.16 & 0.18 & 0.18 & 0.19 & 0.05 & 0.09 & 0.11 \\
\hline Mg & 0.11 & 0.27 & 0.19 & 0.12 & 0.25 & 0.09 & 0.12 & 0.10 & 0.07 & 0.16 & 0.27 & 0.18 & 0.27 & 0.20 & 0.23 & 0.05 & 0.05 & 0.17 \\
\hline Ti & 0.03 & 0.00 & 0.00 & 0.03 & 0.00 & 0.00 & 0.05 & 0.00 & 0.00 & 0.03 & 0.00 & 0.07 & 0.00 & 0.04 & 0.00 & 0.00 & 0.00 & 0.05 \\
\hline$\sum$ oct. & 2.03 & 2.04 & 2.01 & 2.03 & 2.07 & 2.04 & 2.05 & 2.08 & 2.05 & 2.01 & 2.03 & 2.04 & 2.00 & 2.04 & 2.02 & 2.04 & 2.05 & 2.02 \\
\hline K & 0.87 & 0.78 & 0.92 & 0.81 & 0.79 & 0.93 & 0.79 & 0.76 & 0.87 & 0.80 & 0.88 & 0.91 & 0.89 & 0.92 & 0.96 & 0.88 & 0.76 & 0.90 \\
\hline $\mathrm{Na}$ & 0.00 & 0.00 & 0.00 & 0.07 & 0.00 & 0.00 & 0.12 & 0.06 & 0.00 & 0.00 & 0.00 & 0.00 & 0.00 & 0.00 & 0.00 & 0.00 & 0.10 & 0.00 \\
\hline $\mathrm{Ca}$ & 0.00 & 0.00 & 0.00 & 0.00 & 0.00 & 0.00 & 0.00 & 0.00 & 0.00 & 0.00 & 0.00 & 0.00 & 0.00 & 0.00 & 0.00 & 0.00 & 0.00 & 0.00 \\
\hline$\Sigma$ int. & 0.87 & 0.78 & 0.92 & 0.89 & 0.79 & 0.93 & 0.91 & 0.82 & 0.87 & 0.80 & 0.88 & 0.91 & 0.89 & 0.92 & 0.96 & 0.88 & 0.86 & 0.90 \\
\hline
\end{tabular}


charge contents in dioctahedral micas within each sample. In the interlayer charge-Si diagram (Fig. 6a), the illitic and Tschermak substitutions are present. In the $(\mathrm{Fe}+\mathrm{Mg})$-Si diagram (Fig. $6 \mathrm{~b}$ ), most of the analyses plot above the line for ideal Tschermak substitution $\left(\left(\mathrm{Mg}, \mathrm{Fe}^{+2}\right)^{\mathrm{VI}}, \mathrm{Si}^{\mathrm{IV}}=\mathrm{Al}^{\mathrm{VI}}, \mathrm{Al}^{\mathrm{IV}}\right)$, indicating that, besides Tschermak substitution, a ferrimuscovite/ ferriceladonite $\left(\mathrm{Fe}^{+3}\right.$ substituting for $\left.\mathrm{Al}\right)$ components are also present. Guidotti et al. (1994a) demonstrated that, even in medium redox paragenesis, containing ilmenite + magnetite, the $\mathrm{Fe}^{+3} / \mathrm{Fe}_{\text {tot }}$ ratio is over 0.60 . In most of the metapelites, iron oxides and less frequently ilmenite was identified by SEM, indicating oxidizing conditions. On the contrary, in mudstone $\mathrm{N} 4$, that contains pyrite and scarce sphalerite, half of the analyses plot along the line for ideal Tschermak substitution.

In most of the micas, $\mathrm{Na} / \mathrm{Na}+\mathrm{K}$ are lower than 0.05 , indicating minor paragonitic substitution (Guidotti, 1984; Guidotti et al., 1994b). However, in 28\% of the analysed grains this ratio reaches values in the range of 0.05-0.17, and even an isolated value of 0.36 (Table 2,
N4 1-5). Paragonitic substitution is more extended in micas from samples corresponding to Cordillera Oriental than in those from Puna.

Even though KI values show an increase in metamorphic grade in an east to west direction, from Cordillera Oriental to Puna, the compositional range for micas of the two areas overlap each other (Fig. 6). The wide compositional range exhibited by dioctahedral micas from the two areas probably derived from the mixture of grains of detrital and neoformed origin.

\subsubsection{Chlorites}

From the seven samples studied by SEM only N4, $\mathrm{Y} 5$ and $\mathrm{E} 4$ contain chlorite. Analyses with evidence of contamination, exhibiting $\mathrm{Na}_{2} \mathrm{O}+\mathrm{K}_{2} \mathrm{O}+\mathrm{CaO}$ contents of over $1 \%$ were not included in table 3 nor plotted. In the mudstone from the Nazareno area (N4) chlorite is scarce and occurs in tiny tabular grains that frequently are under the resolution of the EDS, consequently few analyses were obtained for this sample.

Chlorites from samples from high anchizone and epizone, Y5 and E4, overlap each other in the
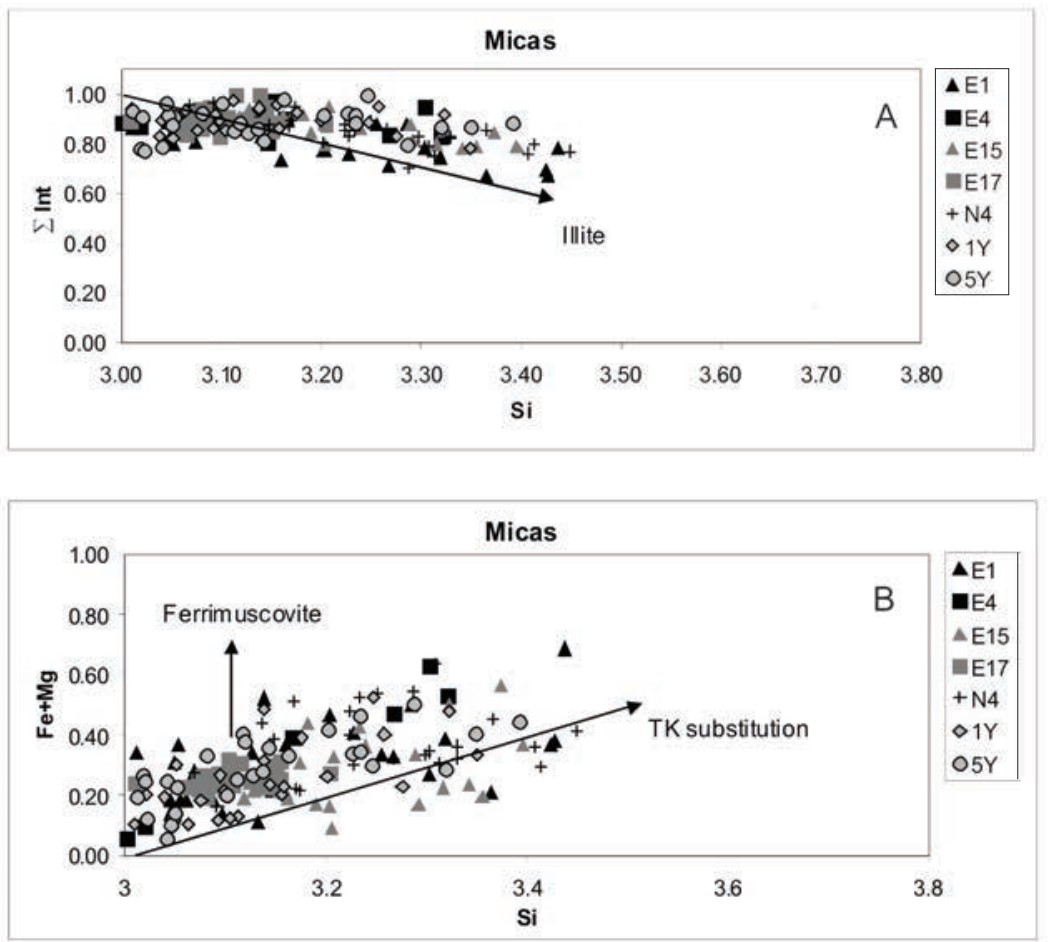

FIG. 6. Compositional diagrams for dioctahedral micas from Ordovician metapelites and metavolcanic rocks: A. $\sum$ Int-Si plot. B. $\left(\mathrm{Fe}^{+2}+\mathrm{Mg}\right)-\mathrm{Si}$ plot. 
TABLE 3. SELECTED EDS ANALYSIS OF CHLORITE.

\begin{tabular}{|c|c|c|c|c|c|c|c|c|c|c|c|c|}
\hline \multirow{2}{*}{ Element } & \multicolumn{12}{|c|}{ E4 } \\
\hline & $2-1$ & $2-2$ & $2-3$ & $2-4$ & $2-5$ & $2-6$ & $3-1$ & $3-4$ & $4-1$ & $4-2$ & 4-3 & $4-4$ \\
\hline $\mathbf{S i}$ & 2.80 & 2.66 & 2.61 & 2.53 & 2.75 & 2.48 & 2.83 & 2.57 & 2.63 & 2.75 & 2.59 & 2.73 \\
\hline $\mathrm{Al}^{\mathrm{IV}}$ & 1.20 & 1.34 & 1.39 & 1.47 & 1.25 & 1.52 & 1.17 & 1.43 & 1.37 & 1.25 & 1.41 & 1.27 \\
\hline $\mathrm{Al}^{\mathrm{VI}}$ & 1.90 & 1.82 & 1.72 & 1.79 & 1.97 & 1.71 & 1.86 & 1.73 & 1.83 & 1.89 & 1.74 & 1.83 \\
\hline $\mathbf{T i}$ & 0.00 & 0.00 & 0.06 & 0.00 & 0.00 & 0.00 & 0.00 & 0.00 & 0.00 & 0.00 & 0.00 & 0.00 \\
\hline $\mathrm{Fe}$ & 2.50 & 2.58 & 2.58 & 2.81 & 2.52 & 2.83 & 2.57 & 2.84 & 2.55 & 2.53 & 2.77 & 2.60 \\
\hline Mn & 0.00 & 0.00 & 0.00 & 0.00 & 0.00 & 0.00 & 0.00 & 0.00 & 0.00 & 0.00 & 0.00 & 0.00 \\
\hline Mg & 1.24 & 1.36 & 1.38 & 1.24 & 1.12 & 1.37 & 1.22 & 1.27 & 1.35 & 1.23 & 1.33 & 1.25 \\
\hline Eoct & 5.64 & 5.76 & 5.74 & 5.84 & 5.60 & 5.91 & 5.65 & 5.85 & 5.73 & 5.65 & 5.83 & 5.68 \\
\hline K & 0.03 & 0.00 & 0.00 & 0.00 & 0.08 & 0.00 & 0.00 & 0.00 & 0.07 & 0.06 & 0.00 & 0.07 \\
\hline $\mathrm{Na}$ & 0.00 & 0.00 & 0.06 & 0.00 & 0.00 & 0.00 & 0.00 & 0.00 & 0.00 & 0.00 & 0.00 & 0.00 \\
\hline
\end{tabular}

\begin{tabular}{|c|c|c|c|c|c|c|c|c|c|c|c|c|}
\hline \multirow{2}{*}{ Element } & \multicolumn{12}{|c|}{ E4 } \\
\hline & 4-6 & 4-9 & $5-1$ & $5-3$ & $5-4$ & $5-8$ & 6-1 & $6-5$ & $7-1$ & $7-2$ & $7-4$ & $7-6$ \\
\hline $\mathbf{S i}$ & 2.77 & 2.63 & 2.67 & 2.60 & 2.63 & 2.79 & 2.74 & 2.50 & 2.57 & 2.55 & 2.62 & 2.57 \\
\hline $\mathrm{Al}^{\mathrm{IV}}$ & 1.23 & 1.37 & 1.33 & 1.40 & 1.37 & 1.21 & 1.26 & 1.50 & 1.43 & 1.45 & 1.38 & 1.43 \\
\hline $\mathbf{A l}^{\mathrm{VI}}$ & 1.98 & 1.81 & 1.80 & 1.84 & 1.80 & 1.81 & 1.86 & 1.72 & 1.75 & 1.73 & 1.80 & 1.69 \\
\hline $\mathbf{T i}$ & 0.00 & 0.00 & 0.00 & 0.00 & 0.00 & 0.00 & 0.00 & 0.00 & 0.00 & 0.00 & 0.00 & 0.00 \\
\hline $\mathrm{Fe}$ & 2.37 & 2.62 & 2.66 & 2.64 & 2.66 & 2.76 & 2.58 & 2.75 & 2.83 & 2.81 & 2.73 & 2.83 \\
\hline Mn & 0.00 & 0.00 & 0.00 & 0.00 & 0.00 & 0.00 & 0.00 & 0.00 & 0.00 & 0.00 & 0.00 & 0.00 \\
\hline Mg & 1.24 & 1.34 & 1.29 & 1.29 & 1.32 & 1.13 & 1.26 & 1.42 & 1.23 & 1.33 & 1.27 & 1.35 \\
\hline Eoct & 5.59 & 5.78 & 5.75 & 5.78 & 5.78 & 5.70 & 5.70 & 5.89 & 5.81 & 5.86 & 5.79 & 5.87 \\
\hline K & 0.08 & 0.00 & 0.04 & 0.00 & 0.00 & 0.00 & 0.00 & 0.00 & 0.05 & 0.00 & 0.00 & 0.00 \\
\hline $\mathrm{Na}$ & 0.00 & 0.00 & 0.00 & 0.00 & 0.00 & 0.00 & 0.00 & 0.00 & 0.00 & 0.00 & 0.00 & 0.00 \\
\hline
\end{tabular}

\begin{tabular}{|c|c|c|c|c|c|c|c|c|c|c|c|c|}
\hline \multirow{2}{*}{ Element } & \multicolumn{12}{|c|}{ E4 } \\
\hline & $7-8$ & $7-9$ & $8-4$ & $8-5$ & $8-7$ & $8-10$ & $9-2$ & $9-4$ & $9-5$ & $9-8$ & $10-1$ & $10-2$ \\
\hline $\mathbf{S i}$ & 2.56 & 2.58 & 2.47 & 2.51 & 2.63 & 2.64 & 2.51 & 2.46 & 2.56 & 2.57 & 2.41 & 2.46 \\
\hline $\mathrm{Al}^{\mathrm{IV}}$ & 1.44 & 1.42 & 1.53 & 1.49 & 1.37 & 1.36 & 1.49 & 1.54 & 1.44 & 1.43 & 1.59 & 1.54 \\
\hline $\mathbf{A l}^{\mathrm{VI}}$ & 1.73 & 1.70 & 1.70 & 1.71 & 1.80 & 1.82 & 1.74 & 1.65 & 1.70 & 1.83 & 1.62 & 1.68 \\
\hline Ti & 0.00 & 0.00 & 0.00 & 0.00 & 0.00 & 0.00 & 0.00 & 0.00 & 0.00 & 0.00 & 0.00 & 0.00 \\
\hline $\mathrm{Fe}$ & 2.74 & 2.69 & 2.81 & 2.89 & 2.63 & 2.57 & 2.82 & 2.97 & 2.76 & 2.73 & 2.92 & 2.89 \\
\hline Mn & 0.00 & 0.00 & 0.00 & 0.00 & 0.00 & 0.03 & 0.00 & 0.00 & 0.00 & 0.00 & 0.00 & 0.03 \\
\hline Mg & 1.37 & 1.45 & 1.41 & 1.29 & 1.34 & 1.35 & 1.32 & 1.32 & 1.41 & 1.25 & 1.44 & 1.33 \\
\hline Eoct & 5.84 & 5.84 & 5.92 & 5.89 & 5.77 & 5.77 & 5.88 & 5.95 & 5.87 & 5.80 & 5.98 & 5.93 \\
\hline $\mathbf{K}$ & 0.03 & 0.03 & 0.00 & 0.00 & 0.03 & 0.00 & 0.00 & 0.00 & 0.00 & 0.00 & 0.00 & 0.00 \\
\hline $\mathrm{Na}$ & 0.00 & 0.00 & 0.00 & 0.00 & 0.00 & 0.00 & 0.00 & 0.00 & 0.00 & 0.00 & 0.00 & 0.00 \\
\hline
\end{tabular}


Table 3 continued.

\begin{tabular}{|c|c|c|c|c|c|c|c|c|c|c|c|c|}
\hline \multirow{2}{*}{ Element } & \multicolumn{2}{|c|}{ E4 } & \multicolumn{10}{|c|}{ Y5 } \\
\hline & $10-3$ & $10-4$ & $1-1$ & $1-2$ & $1-4$ & $2-1$ & $2-2$ & $2-3$ & $2-4$ & $2-5$ & $2-6$ & $2-10$ \\
\hline Si & 2.74 & 2.73 & 2.67 & 2.48 & 2.60 & 2.63 & 2.66 & 2.52 & 2.52 & 2.63 & 2.62 & 2.59 \\
\hline $\mathbf{A I}^{\mathrm{IV}}$ & 1.26 & 1.27 & 1.33 & 1.52 & 1.40 & 1.37 & 1.34 & 1.48 & 1.48 & 1.37 & 1.38 & 1.41 \\
\hline $\mathrm{Al}^{\mathrm{VI}}$ & 1.84 & 1.93 & 1.64 & 1.61 & 1.68 & 1.80 & 1.70 & 1.68 & 1.59 & 1.60 & 1.66 & 1.63 \\
\hline Ti & 0.00 & 0.00 & 0.00 & 0.00 & 0.00 & 0.00 & 0.00 & 0.00 & 0.00 & 0.00 & 0.00 & 0.00 \\
\hline $\mathbf{F e}$ & 2.65 & 2.49 & 2.88 & 2.87 & 2.68 & 2.48 & 2.51 & 2.71 & 2.92 & 2.68 & 2.67 & 2.88 \\
\hline Mn & 0.00 & 0.00 & 0.00 & 0.00 & 0.00 & 0.00 & 0.00 & 0.00 & 0.00 & 0.04 & 0.00 & 0.00 \\
\hline Mg & 1.23 & 1.24 & 1.32 & 1.47 & 1.50 & 1.50 & 1.62 & 1.52 & 1.43 & 1.57 & 1.51 & 1.38 \\
\hline Eoct & 5.71 & 5.67 & 5.85 & 5.95 & 5.86 & 5.79 & 5.82 & 5.90 & 5.94 & 5.89 & 5.84 & 5.89 \\
\hline $\mathbf{K}$ & 0.00 & 0.00 & 0.00 & 0.00 & 0.00 & 0.00 & 0.00 & 0.00 & 0.00 & 0.00 & 0.04 & 0.00 \\
\hline $\mathrm{Na}$ & 0.00 & 0.00 & 0.00 & 0.00 & 0.00 & 0.00 & 0.00 & 0.00 & 0.00 & 0.00 & 0.00 & 0.00 \\
\hline
\end{tabular}

\begin{tabular}{|c|c|c|c|c|c|c|c|c|c|c|c|c|}
\hline \multirow{2}{*}{ Element } & \multicolumn{12}{|c|}{ Y5 } \\
\hline & $2-11$ & $3-1$ & 3-2 & 3-3 & $4-1$ & $4-2$ & 4-3 & 4-4 & $4-11$ & $5-1$ & $5-2$ & $5-3$ \\
\hline $\mathrm{Si}$ & 2.57 & 2.56 & 2.54 & 2.54 & 2.49 & 2.66 & 2.51 & 2.53 & 2.81 & 2.50 & 2.56 & 2.52 \\
\hline$A I^{I V}$ & 1.43 & 1.44 & 1.46 & 1.46 & 1.51 & 1.34 & 1.49 & 1.47 & 1.19 & 1.50 & 1.44 & 1.48 \\
\hline $\mathbf{A} \mathbf{I}^{\mathrm{VI}}$ & 1.68 & 1.58 & 1.57 & 1.67 & 1.65 & 1.70 & 1.63 & 1.59 & 1.68 & 1.57 & 1.60 & 1.58 \\
\hline $\mathbf{T i}$ & 0.00 & 0.00 & 0.00 & 0.00 & 0.00 & 0.00 & 0.00 & 0.00 & 0.00 & 0.00 & 0.00 & 0.00 \\
\hline $\mathrm{Fe}$ & 2.60 & 2.76 & 2.79 & 2.62 & 2.84 & 2.56 & 2.75 & 2.97 & 2.19 & 2.90 & 2.81 & 2.81 \\
\hline Mn & 0.04 & 0.00 & 0.04 & 0.00 & 0.06 & 0.00 & 0.00 & 0.00 & 0.00 & 0.04 & 0.00 & 0.00 \\
\hline Mg & 1.55 & 1.59 & 1.55 & 1.60 & 1.38 & 1.53 & 1.55 & 1.39 & 1.86 & 1.46 & 1.51 & 1.55 \\
\hline Koct & 5.87 & 5.93 & 5.94 & 5.90 & 5.93 & 5.79 & 5.93 & 5.94 & 5.73 & 5.96 & 5.92 & 5.95 \\
\hline $\mathbf{K}$ & 0.00 & 0.00 & 0.00 & 0.00 & 0.00 & 0.06 & 0.00 & 0.00 & 0.05 & 0.00 & 0.00 & 0.00 \\
\hline $\mathbf{N a}$ & 0.00 & 0.00 & 0.00 & 0.00 & 0.00 & 0.00 & 0.00 & 0.00 & 0.00 & 0.00 & 0.00 & 0.00 \\
\hline
\end{tabular}

\begin{tabular}{|c|c|c|c|c|c|c|c|c|c|c|c|c|}
\hline \multirow{2}{*}{ Element } & \multicolumn{12}{|c|}{ Y5 } \\
\hline & $5-4$ & $6-5$ & $6-6$ & 6-7 & 6-9 & $7-5$ & $7-6$ & $8-1$ & $8-2$ & $8-4$ & $8-5$ & $10-1$ \\
\hline $\mathbf{S i}$ & 2.62 & 2.64 & 2.49 & 2.52 & 2.47 & 2.56 & 2.56 & 2.58 & 2.59 & 2.46 & 2.64 & 2.53 \\
\hline $\mathbf{A l}^{\mathrm{IV}}$ & 1.38 & 1.36 & 1.51 & 1.48 & 1.53 & 1.44 & 1.44 & 1.42 & 1.41 & 1.54 & 1.36 & 1.47 \\
\hline $\mathrm{Al}^{\mathrm{VI}}$ & 1.62 & 1.66 & 1.60 & 1.60 & 1.55 & 1.62 & 1.65 & 1.67 & 1.64 & 1.58 & 1.60 & 1.54 \\
\hline $\mathbf{T i}$ & 0.00 & 0.00 & 0.00 & 0.00 & 0.00 & 0.00 & 0.00 & 0.00 & 0.00 & 0.00 & 0.00 & 0.00 \\
\hline $\mathrm{Fe}$ & 2.76 & 2.55 & 2.82 & 2.73 & 2.84 & 2.94 & 2.62 & 2.64 & 2.82 & 2.81 & 2.74 & 2.78 \\
\hline Mn & 0.00 & 0.00 & 0.05 & 0.05 & 0.05 & 0.00 & 0.05 & 0.00 & 0.00 & 0.00 & 0.04 & 0.00 \\
\hline Mg & 1.48 & 1.64 & 1.48 & 1.56 & 1.55 & 1.35 & 1.57 & 1.58 & 1.43 & 1.58 & 1.49 & 1.64 \\
\hline$\sum$ oct & 5.86 & 5.85 & 5.95 & 5.94 & 5.99 & 5.91 & 5.88 & 5.88 & 5.89 & 5.98 & 5.88 & 5.96 \\
\hline $\mathbf{K}$ & 0.03 & 0.00 & 0.00 & 0.00 & 0.00 & 0.00 & 0.03 & 0.00 & 0.00 & 0.00 & 0.00 & 0.00 \\
\hline $\mathbf{N a}$ & 0.00 & 0.00 & 0.00 & 0.00 & 0.00 & 0.00 & 0.00 & 0.00 & 0.00 & 0.00 & 0.00 & 0.00 \\
\hline
\end{tabular}


Table 3 continued.

\begin{tabular}{|c|c|c|c|c|c|c|c|c|c|c|c|c|}
\hline \multirow{2}{*}{ Element } & \multicolumn{4}{|c|}{ Y5 } & \multicolumn{8}{|c|}{ N4 } \\
\hline & $10-2$ & $10-3$ & $10-5$ & $10-8$ & $5-4$ & 6-1 & $8-5$ & $10-1$ & $10-2$ & $10-3$ & 11-1 & $11-2$ \\
\hline $\mathbf{S i}$ & 2.48 & 2.57 & 2.46 & 2.63 & 2.97 & 2.71 & 3.06 & 2.94 & 2.91 & 2.95 & 3.08 & 2.92 \\
\hline $\mathrm{Al}^{\mathrm{IV}}$ & 1.52 & 1.43 & 1.54 & 1.37 & 1.03 & 1.29 & 0.94 & 1.06 & 1.09 & 1.05 & 0.92 & 1.08 \\
\hline $\mathbf{A l}^{\mathrm{VI}}$ & 1.59 & 1.55 & 1.57 & 1.70 & 1.43 & 1.75 & 1.64 & 1.60 & 1.54 & 1.52 & 1.48 & 1.59 \\
\hline Ti & 0.00 & 0.00 & 0.00 & 0.00 & 0.05 & 0.00 & 0.00 & 0.00 & 0.00 & 0.00 & 0.00 & 0.00 \\
\hline $\mathrm{Fe}$ & 2.89 & 3.01 & 2.89 & 2.72 & 2.37 & 2.59 & 2.33 & 2.66 & 2.79 & 2.33 & 2.51 & 2.07 \\
\hline Mn & 0.00 & 0.00 & 0.00 & 0.00 & 0.04 & 0.00 & 0.05 & 0.00 & 0.06 & 0.00 & 0.06 & 0.00 \\
\hline Mg & 1.49 & 1.38 & 1.52 & 1.42 & 1.87 & 1.42 & 1.62 & 1.43 & 1.39 & 1.90 & 1.65 & 2.05 \\
\hline$\sum$ oct & 5.97 & 5.94 & 5.99 & 5.84 & 5.76 & 5.76 & 5.63 & 5.69 & 5.78 & 5.76 & 5.71 & 5.71 \\
\hline $\mathbf{K}$ & 0.00 & 0.00 & 0.00 & 0.00 & 0.00 & 0.03 & 0.05 & 0.09 & 0.00 & 0.00 & 0.03 & 0.07 \\
\hline $\mathbf{N a}$ & 0.00 & 0.00 & 0.00 & 0.00 & 0.00 & 0.00 & 0.00 & 0.00 & 0.00 & 0.00 & 0.00 & 0.00 \\
\hline
\end{tabular}

Al-Mg-Fe plot (Fig. 7a), they are relatively richer in $\mathrm{Al}$ and poorer in Si than chlorites from the mudstone from the Nazareno area, where Ordovician rocks only attained advanced diagenesis according to KI values. In the $\mathrm{Fe}+\mathrm{Mg}$ versus $\mathrm{Si}$ diagram (Fig. 7b, Wiewiöra and Weiss, 1990), chlorites from the three samples show a similar degree of di/trioctahedral substitution toward the sudoite end-member and show ${ }^{\mathrm{VI}} \mathrm{Al}>{ }^{\mathrm{IV}} \mathrm{Al}$, as is characteristic of chlorites formed at low temperatures. However, several chlorite formulae corresponding to slates E4 and Y5 depict Si contents below 2.60 a.p.f.u. and sum of octhaedral cations close to the ideal value of 6 , which is uncommon in anchizonal metapelites. On the other hand, chlorites from the diagenetic sample have slightly lower octahedral occupancies (Fig. 7c) and higher Tschermak substitution (TK) ${ }^{\mathrm{IV}} \mathrm{Al}{ }^{\mathrm{VI}} \mathrm{Al}-$ $\mathrm{Si}_{-1}(\mathrm{Mg}, \mathrm{Fe})_{-1}$ than chlorites from anchizonal-epizonal samples. Furthermore, in sample $\mathrm{E} 4 \mathrm{Fe}_{\text {tot }} /\left(\mathrm{Fe}_{\text {tot }}+\mathrm{Mg}\right)$ varies by less than 0.1 , suggesting that chemical equilibrium was approached, on the contrary this ratio varies by 0.17 and 0.15 , respectively in samples N4 and Y5 (Table 3).

\subsubsection{Mixed-Layers}

For the slate E1 and the metaandesite E17, EDS analyses corroborate the occurrence of complex mixed-layered phases (Table 4) and the absence of chlorite in agreement with XRD analysis. Moreover, for the metapelites N4, E4 and Y1several analyses matching with chlorite-bearing mixed-layers were obtained, even though phases like that were not detected by XRD analyses. Thus, they could correspond to intergrows of chlorite with other phyllosilicates below the resolution of EDS or to minor mixed-layer phases not detected by XRD. Compositions of mixed-layers were represented in a $(\mathrm{Fe}+\mathrm{Mg}) / \mathrm{Si}$-Interlayer sum/Si (Fig. 8), because it is not affected by the normalization criterion employed, and clearly discriminates among $\mathrm{Ms} / \mathrm{Chl}, \mathrm{Bt} / \mathrm{Chl}$ and $\mathrm{Chl} / \mathrm{Sm}$ mixed-layers (Do Campo and Nieto, 2005). This diagram also enables the identification of more complex mixed-layer sequences composed of three different kinds of layers. Representative analyses of chlorite, biotite and smectite, plus $0.5 / 0.5$ mixtures of muscovite-chlorite $(0.5 / 0.5 \mathrm{Ms}-\mathrm{Chl})$, chlorite-smectite $(0.5 / 0.5 \mathrm{Chl}-\mathrm{Sm})$, and biotite-chlorite, are also included in figure 8 for reference. Mixed-layers from slate E1 mainly plot around the point corresponding to 0.5/0.5 Ms-Chl, although they exhibit a considerable scatter towards $0.5 / 0.5 \mathrm{Chl}-\mathrm{Sm}$.

Mixed-layers from metaandesite E17 show sum of octahedral cations from 7.23 to 8.13 implying that it comprises dioctahedral and trioctahedral layers. They depict a narrow range of $\mathrm{Fe} /(\mathrm{Fe}+\mathrm{Mg})$, with most of the values close to $0.5 \mathrm{~K}$ is the main interlayer cation, with subordinate $\mathrm{Ca}$, and sometimes $\mathrm{Na}$. Most of the analyses plot between $\mathrm{Chl} / \mathrm{Sm}$ and $\mathrm{Chl} / \mathrm{Ms}$ compositions in the $\mathrm{Int}_{\text {charge }} / \mathrm{Si}-\mathrm{Fe}+\mathrm{Mg} / \mathrm{Si}$ diagram (Fig. 8), however, XRD data do not match with any of these two components mixed-layers. Consequently, the characterization of this mixed-layered mineral would require additional High-resolution transmission electron microscopy study. 

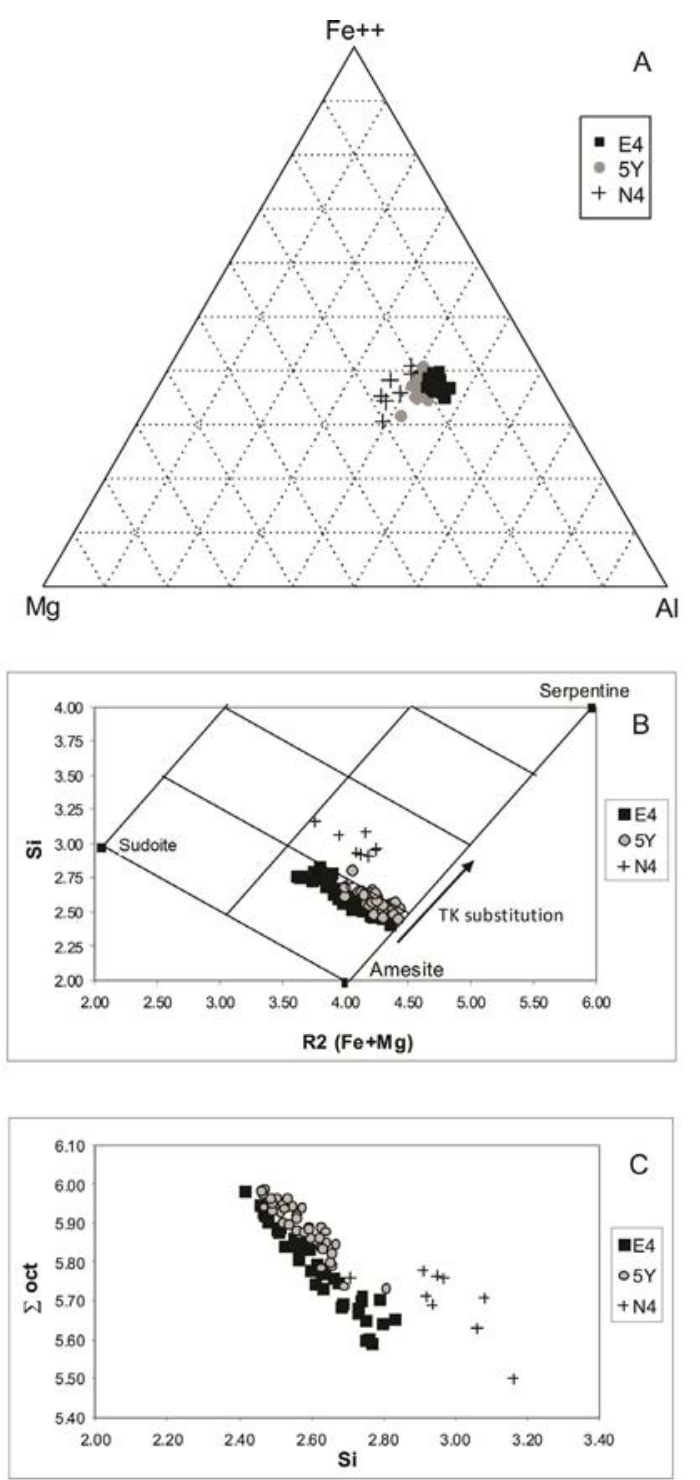

FIG. 7. Compositional diagram for chlorites: A. Triangular Fe-Mg-Al plot; B. Fetot + Mg versus Si plot; C. Eoct-Si plot.

Most of the analyses from mudstone N4 as well as few from slate E4 plot to the left of the upper line that connects the chlorite and 0.5/0.5 ChlSm composition, thus vermiculite-like layers are probably the third component of some of these mixed-layers sequences (Fig. 8). On the other hand, for slateY1 the few analyses compatible with chlorite-bearing mixed-layers correspond to IPG (Fig. 4c) or biotite grains, both detrital in origin. They plot near the point corresponding to $0.5 / 0.5$ Ms-Chl compositions.

\subsubsection{Sulfates}

The metaandesite E 17 contain sulfates of the alunite-jarosite family (Table 5), mainly jarosite showing solid-solution with natrojarosite $(\mathrm{Na} / \mathrm{K}$ : 0-0.46), phosphate $\left(\mathrm{PO}_{4} / \mathrm{SO}_{4}: 0.05\right.$ to 0.30$)$ and minor alunite $\left(\mathrm{Al}^{+3}\right.$ by $\left.\mathrm{Fe}^{+3}\right)$. Structural formulae frequently show deficiencies on the alkali site occupancy from 0.05 to 0.22 . Likewise, deficiencies in alkali site content have been reported for synthetically prepared jarosites, which are generally ascribed to hydronium substitution (Stoffregen, 1993, and references therein). 
TABLE 4. SELECTED EDS ANALYSIS OF MIXED-LAYERS.

\begin{tabular}{|c|c|c|c|c|c|c|c|c|c|c|c|c|c|c|c|c|c|c|}
\hline \multirow{2}{*}{ Element } & \multicolumn{18}{|c|}{ E1 } \\
\hline & $3-2$ & $3-5$ & $3-6$ & 3-8 & 4-1 & $4-2$ & $4-4$ & $4-6$ & 4-8 & $5-1$ & $5-3$ & $5-4$ & $5-5$ & $7-1$ & $7-2$ & $7-3$ & $7-4$ & $7-8$ \\
\hline $\mathbf{S i}$ & 6.21 & 6.75 & 6.30 & 6.92 & 6.02 & 6.48 & 6.06 & 6.00 & 6.79 & 5.97 & 5.90 & 5.78 & 6.47 & 5.98 & 5.99 & 6.19 & 6.48 & 6.10 \\
\hline $\mathrm{Al}^{\mathrm{IV}}$ & 1.79 & 1.25 & 1.70 & 1.08 & 1.98 & 1.52 & 1.94 & 2.00 & 1.21 & 2.03 & 2.10 & 2.22 & 1.53 & 2.02 & 2.01 & 1.81 & 1.52 & 1.90 \\
\hline $\mathrm{Al}^{\mathrm{VI}}$ & 2.86 & 2.68 & 2.70 & 2.84 & 2.81 & 2.74 & 2.71 & 2.68 & 3.01 & 2.46 & 2.85 & 2.46 & 2.65 & 2.48 & 2.49 & 2.61 & 3.04 & 2.77 \\
\hline $\mathbf{T i}$ & 0.00 & 0.00 & 0.00 & 0.07 & 0.00 & 0.00 & 0.00 & 0.00 & 0.00 & 0.00 & 0.00 & 0.00 & 0.00 & 0.00 & 0.00 & 0.00 & 0.00 & 0.00 \\
\hline $\mathrm{Fe}$ & 3.20 & 3.12 & 3.31 & 2.43 & 3.27 & 3.29 & 3.48 & 3.51 & 2.55 & 3.68 & 3.56 & 3.81 & 3.54 & 3.76 & 3.58 & 3.25 & 2.83 & 3.18 \\
\hline Mn & 0.00 & 0.00 & 0.00 & 0.00 & 0.00 & 0.00 & 0.00 & 0.00 & 0.00 & 0.00 & 0.00 & 0.00 & 0.00 & 0.00 & 0.00 & 0.00 & 0.00 & 0.06 \\
\hline Mg & 1.96 & 2.04 & 2.09 & 1.97 & 2.03 & 1.98 & 2.00 & 2.11 & 1.90 & 2.22 & 1.66 & 2.17 & 1.87 & 2.07 & 2.25 & 2.26 & 2.03 & 2.12 \\
\hline Eoct & 8.03 & 7.84 & 8.10 & 7.31 & 8.11 & 8.01 & 8.19 & 8.29 & 7.46 & 8.36 & 8.07 & 8.44 & 8.06 & 8.31 & 8.32 & 8.11 & 7.91 & 8.14 \\
\hline K & 0.71 & 0.78 & 0.81 & 1.10 & 0.95 & 0.66 & 0.61 & 0.73 & 1.08 & 0.84 & 1.11 & 0.74 & 0.62 & 0.71 & 0.74 & 0.81 & 0.66 & 0.68 \\
\hline $\mathrm{Na}$ & 0.00 & 0.00 & 0.00 & 0.16 & 0.00 & 0.00 & 0.00 & 0.00 & 0.00 & 0.00 & 0.00 & 0.00 & 0.00 & 0.00 & 0.00 & 0.00 & 0.00 & 0.00 \\
\hline $\mathbf{C a}$ & 0.08 & 0.06 & 0.00 & 0.11 & 0.00 & 0.05 & 0.13 & 0.00 & 0.10 & 0.00 & 0.00 & 0.07 & 0.07 & 0.10 & 0.07 & 0.08 & 0.00 & 0.09 \\
\hline$\Sigma$ int. & 0.88 & 0.89 & 0.81 & 1.49 & 0.95 & 0.77 & 0.86 & 0.73 & 1.29 & 0.84 & 1.11 & 0.88 & 0.76 & 0.91 & 0.87 & 0.97 & 0.66 & 0.86 \\
\hline
\end{tabular}

\begin{tabular}{|c|c|c|c|c|c|c|c|c|c|c|c|c|c|c|c|c|c|c|}
\hline \multirow{2}{*}{ Element } & \multicolumn{9}{|c|}{ E1 } & \multicolumn{5}{|c|}{ E4 } & \multicolumn{4}{|c|}{ Y1 } \\
\hline & $8-1$ & $8-2$ & $8-3$ & $9-1$ & $9-2$ & $9-7$ & $10-1$ & $10-2$ & $10-3$ & $3-3$ & $3-5$ & $7-3$ & $8-2$ & $9-1$ & $1-1 *$ & $2-3 *$ & $3-1^{*}$ & $5-2 *$ \\
\hline $\mathbf{S i}$ & 6.21 & 6.23 & 6.36 & 6.09 & 6.81 & 6.16 & 6.26 & 6.34 & 6.13 & 4.79 & 4.96 & 5.15 & 5.47 & 5.22 & 5.90 & 5.89 & 6.02 & 5.77 \\
\hline $\mathrm{Al}^{\mathrm{IV}}$ & 1.79 & 1.77 & 1.64 & 1.91 & 1.19 & 1.84 & 1.74 & 1.66 & 1.87 & 3.21 & 3.04 & 2.85 & 2.53 & 2.78 & 2.10 & 2.11 & 1.98 & 2.23 \\
\hline $\mathrm{Al}^{\mathrm{VI}}$ & 2.79 & 2.87 & 3.40 & 2.49 & 2.76 & 2.64 & 2.53 & 2.59 & 2.56 & 2.42 & 2.53 & 2.73 & 2.62 & 2.73 & 2.59 & 2.65 & 2.75 & 2.95 \\
\hline $\mathbf{T i}$ & 0.00 & 0.00 & 0.00 & 0.00 & 0.00 & 0.00 & 0.00 & 0.00 & 0.00 & 0.00 & 0.00 & 0.00 & 0.00 & 0.00 & 0.00 & 0.00 & 0.00 & 0.00 \\
\hline $\mathrm{Fe}$ & 3.25 & 3.03 & 2.59 & 3.38 & 2.64 & 3.25 & 3.33 & 3.22 & 3.45 & 4.60 & 4.70 & 4.07 & 3.89 & 4.21 & 3.58 & 3.66 & 3.60 & 3.41 \\
\hline Mn & 0.00 & 0.00 & 0.00 & 0.00 & 0.00 & 0.00 & 0.00 & 0.00 & 0.00 & 0.00 & 0.00 & 0.00 & 0.00 & 0.00 & 0.00 & 0.00 & 0.00 & 0.00 \\
\hline Mg & 2.04 & 2.06 & 1.62 & 2.27 & 2.17 & 2.28 & 2.33 & 2.32 & 2.25 & 2.27 & 1.71 & 2.14 & 2.19 & 1.96 & 2.15 & 1.93 & 1.80 & 1.81 \\
\hline$\sum$ oct & 8.07 & 7.96 & 7.61 & 8.14 & 7.57 & 8.17 & 8.18 & 8.14 & 8.26 & 9.29 & 8.94 & 8.94 & 8.70 & 8.91 & 8.32 & 8.24 & 8.15 & 8.17 \\
\hline $\mathbf{K}$ & 0.86 & 0.79 & 0.90 & 0.75 & 1.05 & 0.54 & 0.68 & 0.59 & 0.62 & 0.20 & 0.25 & 0.09 & 0.52 & 0.23 & 0.86 & 0.97 & 0.94 & 0.95 \\
\hline $\mathrm{Na}$ & 0.00 & 0.00 & 0.00 & 0.19 & 0.00 & 0.00 & 0.00 & 0.00 & 0.00 & 0.00 & 0.11 & 0.14 & 0.00 & 0.00 & 0.00 & 0.00 & 0.00 & 0.00 \\
\hline $\mathrm{Ca}$ & 0.00 & 0.09 & 0.06 & 0.10 & 0.12 & 0.16 & 0.08 & 0.10 & 0.08 & 0.00 & 0.13 & 0.00 & 0.00 & 0.00 & 0.00 & 0.00 & 0.00 & 0.00 \\
\hline$\Sigma$ int. & 0.86 & 0.97 & 1.01 & 1.14 & 1.29 & 0.86 & 0.84 & 0.80 & 0.79 & 0.20 & 0.62 & 0.23 & 0.52 & 0.23 & 0.86 & 0.97 & 0.94 & 0.95 \\
\hline
\end{tabular}

$*$ detrital grains. 


\begin{tabular}{|c|c|c|c|c|c|c|c|c|c|c|c|c|c|c|c|c|c|c|}
\hline \multirow{2}{*}{ Element } & \multicolumn{18}{|c|}{ E 17} \\
\hline & $5-2$ & $5-7$ & $6-8$ & $7-3$ & $9-5$ & $10-10$ & $10-17$ & 11-1 & 11-2 & $11-3$ & 11-4 & $12-5$ & $12-6$ & $15-2$ & $18-1$ & $18-2$ & $18-5$ & $18-6$ \\
\hline Si & 6.80 & 6.62 & 6.91 & 6.75 & 7.55 & 6.61 & 7.43 & 7.01 & 6.73 & 6.83 & 7.20 & 7.12 & 7.03 & 6.72 & 6.55 & 6.90 & 6.24 & 6.70 \\
\hline $\mathrm{Al}^{\mathrm{IV}}$ & 1.20 & 1.38 & 1.09 & 1.25 & 0.45 & 1.39 & 0.57 & 0.99 & 1.27 & 1.17 & 0.80 & 0.88 & 0.97 & 1.28 & 1.45 & 1.10 & 1.76 & 1.30 \\
\hline $\mathbf{A l}^{\mathrm{VI}}$ & 2.64 & 2.42 & 2.43 & 2.53 & 2.74 & 2.68 & 2.71 & 2.55 & 2.55 & 2.89 & 2.62 & 2.45 & 2.34 & 2.61 & 2.28 & 2.30 & 3.23 & 2.36 \\
\hline $\mathbf{T i}$ & 0.05 & 0.00 & 0.00 & 0.00 & 0.00 & 0.00 & 0.00 & 0.00 & 0.00 & 0.00 & 0.00 & 0.00 & 0.00 & 0.00 & 0.05 & 0.00 & 0.00 & 0.00 \\
\hline $\mathrm{Fe}$ & 2.62 & 2.84 & 3.14 & 2.83 & 2.26 & 2.63 & 2.36 & 2.57 & 2.82 & 2.36 & 2.54 & 2.55 & 2.73 & 2.69 & 2.89 & 2.52 & 2.05 & 2.83 \\
\hline Mn & 0.00 & 0.00 & 0.00 & 0.00 & 0.00 & 0.00 & 0.00 & 0.00 & 0.00 & 0.00 & 0.00 & 0.00 & 0.00 & 0.00 & 0.00 & 0.00 & 0.04 & 0.00 \\
\hline Mg & 2.54 & 2.76 & 2.19 & 2.67 & 2.22 & 2.66 & 2.23 & 2.41 & 2.61 & 2.50 & 2.34 & 2.44 & 2.60 & 2.55 & 2.90 & 3.08 & 2.68 & 2.68 \\
\hline$\sum$ oct & 7.85 & 8.02 & 7.76 & 8.03 & 7.23 & 7.96 & 7.30 & 7.52 & 7.97 & 7.74 & 7.49 & 7.44 & 7.67 & 7.85 & 8.13 & 7.90 & 8.00 & 7.86 \\
\hline $\mathbf{K}$ & 0.38 & 0.64 & 0.68 & 0.27 & 0.82 & 0.62 & 0.78 & 0.84 & 0.62 & 0.53 & 0.81 & 0.75 & 0.86 & 0.56 & 0.43 & 0.59 & 0.33 & 0.45 \\
\hline $\mathrm{Na}$ & 0.20 & 0.00 & 0.28 & 0.00 & 0.00 & 0.00 & 0.20 & 0.17 & 0.00 & 0.00 & 0.17 & 0.26 & 0.16 & 0.14 & 0.00 & 0.00 & 0.00 & 0.18 \\
\hline $\mathrm{Ca}$ & 0.09 & 0.15 & 0.09 & 0.19 & 0.21 & 0.08 & 0.14 & 0.19 & 0.08 & 0.13 & 0.11 & 0.27 & 0.13 & 0.13 & 0.18 & 0.21 & 0.10 & 0.29 \\
\hline$\Sigma$ int. & 0.76 & 0.93 & 1.13 & 0.65 & 1.25 & 0.79 & 1.26 & 1.40 & 0.77 & 0.79 & 1.20 & 1.55 & 1.28 & 0.96 & 0.80 & 1.00 & 0.53 & 1.21 \\
\hline
\end{tabular}

\begin{tabular}{|c|c|c|c|c|c|c|c|c|c|c|c|c|c|c|c|c|c|c|}
\hline \multirow{2}{*}{ Element } & \multicolumn{18}{|c|}{ N4 } \\
\hline & $1-4$ & $1-6$ & $3-1$ & $3-2$ & $3-3$ & $3-4$ & 4-1 & $4-3$ & $5-1$ & $5-3$ & $5-9$ & $6-2$ & $6-3$ & $6-5$ & $7-1$ & $7-2$ & $7-3$ & $7-4$ \\
\hline $\mathbf{S i}$ & 6.07 & 5.73 & 5.58 & 5.95 & 6.31 & 5.83 & 6.00 & 6.19 & 5.46 & 5.69 & 5.76 & 5.84 & 5.73 & 5.77 & 5.40 & 5.66 & 5.80 & 5.64 \\
\hline $\mathbf{A l}^{\mathrm{IV}}$ & 1.93 & 2.27 & 2.42 & 2.05 & 1.69 & 2.17 & 2.00 & 1.81 & 2.54 & 2.31 & 2.24 & 2.16 & 2.27 & 2.23 & 2.60 & 2.34 & 2.20 & 2.36 \\
\hline $\mathbf{A l}^{\mathrm{VI}}$ & 3.14 & 2.95 & 2.04 & 2.67 & 2.96 & 2.44 & 2.51 & 3.17 & 1.68 & 2.53 & 2.55 & 2.38 & 2.41 & 2.51 & 2.30 & 2.37 & 2.33 & 2.25 \\
\hline $\mathbf{T i}$ & 0.00 & 0.00 & 0.00 & 0.00 & 0.00 & 0.25 & 0.15 & 0.00 & 0.16 & 0.00 & 0.00 & 0.00 & 0.18 & 0.00 & 0.14 & 0.00 & 0.14 & 0.00 \\
\hline $\mathrm{Fe}$ & 3.63 & 3.38 & 4.58 & 3.21 & 3.02 & 3.54 & 3.54 & 2.93 & 4.19 & 3.87 & 3.61 & 4.05 & 3.91 & 3.26 & 3.99 & 3.64 & 4.00 & 4.51 \\
\hline Mn & 0.00 & 0.00 & 0.00 & 0.00 & 0.00 & 0.06 & 0.00 & 0.06 & 0.07 & 0.00 & 0.00 & 0.00 & 0.00 & 0.00 & 0.06 & 0.00 & 0.00 & 0.00 \\
\hline Mg & 1.34 & 1.92 & 2.46 & 2.43 & 2.02 & 1.99 & 2.20 & 1.67 & 3.01 & 2.32 & 2.45 & 2.33 & 1.96 & 2.87 & 2.30 & 2.77 & 2.12 & 2.20 \\
\hline$\sum$ oct & 8.11 & 8.25 & 9.09 & 8.31 & 8.01 & 8.27 & 8.40 & 7.82 & 9.11 & 8.72 & 8.62 & 8.75 & 8.46 & 8.64 & 8.80 & 8.77 & 8.59 & 8.96 \\
\hline $\mathbf{K}$ & 0.57 & 0.81 & 0.20 & 0.74 & 0.71 & 0.51 & 0.38 & 0.99 & 0.33 & 0.35 & 0.44 & 0.28 & 0.58 & 0.44 & 0.41 & 0.19 & 0.33 & 0.18 \\
\hline $\mathrm{Na}$ & 0.00 & 0.00 & 0.00 & 0.00 & 0.00 & 0.17 & 0.00 & 0.00 & 0.00 & 0.00 & 0.00 & 0.00 & 0.00 & 0.00 & 0.00 & 0.23 & 0.00 & 0.00 \\
\hline $\mathrm{Ca}$ & 0.00 & 0.00 & 0.00 & 0.00 & 0.00 & 0.00 & 0.00 & 0.00 & 0.00 & 0.00 & 0.00 & 0.00 & 0.00 & 0.00 & 0.00 & 0.00 & 0.04 & 0.00 \\
\hline$\Sigma$ int. & 0.57 & 0.81 & 0.20 & 0.74 & 0.71 & 0.69 & 0.38 & 0.99 & 0.33 & 0.35 & 0.44 & 0.28 & 0.58 & 0.44 & 0.41 & 0.43 & 0.42 & 0.18 \\
\hline
\end{tabular}


Table 4 continued.

\begin{tabular}{|c|c|c|c|c|c|c|c|c|c|c|c|c|}
\hline \multirow{2}{*}{ Element } & \multicolumn{12}{|c|}{ N4 } \\
\hline & $7-5$ & $7-10$ & $8-1$ & 8-2 & 8-3 & $8-4$ & 8-11 & $9-2$ & $10-4$ & $10-8$ & $10-9$ & 11-3 \\
\hline $\mathbf{S i}$ & 5.48 & 5.29 & 5.89 & 5.78 & 5.75 & 5.39 & 6.30 & 6.09 & 5.87 & 5.70 & 5.80 & 5.75 \\
\hline $\mathbf{A l}^{\mathrm{IV}}$ & 2.52 & 2.71 & 2.11 & 2.22 & 2.25 & 2.61 & 1.70 & 1.91 & 2.13 & 2.30 & 2.20 & 2.25 \\
\hline $\mathbf{A l}^{\mathrm{VI}}$ & 2.17 & 2.29 & 2.29 & 1.95 & 2.30 & 2.13 & 2.65 & 2.37 & 2.40 & 2.57 & 2.27 & 2.30 \\
\hline $\mathrm{Ti}$ & 0.00 & 0.00 & 0.09 & 0.00 & 0.00 & 0.00 & 0.15 & 0.10 & 0.00 & 0.00 & 0.00 & 0.00 \\
\hline $\mathrm{Fe}$ & 4.14 & 3.94 & 3.70 & 4.23 & 3.34 & 4.04 & 3.46 & 3.83 & 3.54 & 4.19 & 4.23 & 3.90 \\
\hline Mn & 0.06 & 0.07 & 0.00 & 0.00 & 0.00 & 0.07 & 0.00 & 0.00 & 0.08 & 0.00 & 0.10 & 0.08 \\
\hline Mg & 2.69 & 2.77 & 2.58 & 2.81 & 3.15 & 2,84 & 1.80 & 2.14 & 2.70 & 1.94 & 2.23 & 2.52 \\
\hline Eoct & 9.06 & 9.06 & 8.67 & 9.00 & 8.79 & 9.07 & 8.05 & 8.45 & 8.73 & 8.70 & 8.82 & 8.80 \\
\hline $\mathbf{K}$ & 0.22 & 0.18 & 0.29 & 0.26 & 0.36 & 0.34 & 0.44 & 0.42 & 0.25 & 0.34 & 0.28 & 0.35 \\
\hline $\mathrm{Na}$ & 0.00 & 0.00 & 0.00 & 0.00 & 0.00 & 0.00 & 0.19 & 0.00 & 0.00 & 0.00 & 0.00 & 0.00 \\
\hline $\mathrm{Ca}$ & 0.00 & 0.05 & 0.00 & 0.00 & 0.00 & 0.00 & 0.00 & 0.00 & 0.00 & 0.00 & 0.00 & 0.00 \\
\hline$\Sigma$ int. & 0.22 & 0.29 & 0.29 & 0.26 & 0.36 & 0.34 & 0.64 & 0.42 & 0.25 & 0.34 & 0.28 & 0.35 \\
\hline
\end{tabular}

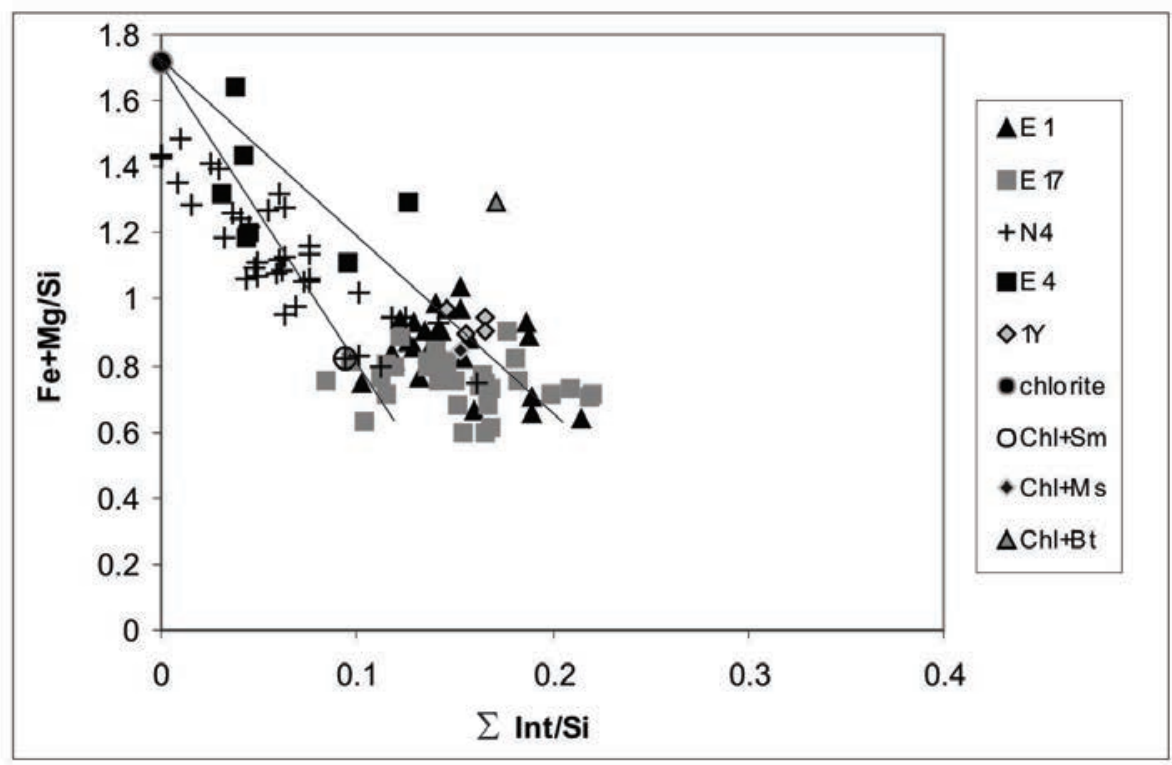

FIG. 8. Chemical variations of mixed-layers on the $\mathrm{Na}+\mathrm{K}+\mathrm{Ca} / \mathrm{Si}$ versus $\mathrm{Fe}+\mathrm{Mg} / \mathrm{Si}$ diagram. Representative analyses of chlorite, plus 0.5/0.5 mixtures of muscovite-chlorite, chlorite-smectite and biotite-chlorite were included in order to use them as a reference.

\section{Discussion}

\subsection{Clay Mineral reaction progress}

Based on KI values and occurrence (or absence) of slaty cleavage the studied rocks can be divided in three groups:
1. Almost all the mudstones from the eastern flank of Sierra de Santa Victoria (Nazareno and Santa Victoria River) show KI values in the range of deep diagenesis-low anchizone (0.69 to $0.47^{\circ}$ $\Delta 2 \theta)$ and rough anastomosing bedding-parallel microfabric $\left(\mathrm{S}_{0}\right)$. The clay mineral assemblages identified in these pelites illite-muscovite+chlorite \pm 
TABLE 5. SELECTED EDS ANALYSIS OF SULFATES.

\begin{tabular}{|c|c|c|c|c|c|c|c|c|c|c|c|c|c|}
\hline Element & $8 / 1$ & 9/17 & $10 / 3$ & $10 / 4$ & $10 / 15$ & $12 / 1$ & $12 / 2$ & $12 / 4$ & $12 / 9$ & $13 / 8$ & $14 / 5$ & $14 / 6$ & $16 / 4$ \\
\hline $\mathbf{N a}$ & 0.00 & 0.11 & 0.00 & 0.12 & 0.13 & 0.22 & 0.00 & 0.09 & 0.12 & 0.11 & 0.00 & 0.00 & 0.26 \\
\hline Mg & 0.00 & 0.05 & 0.00 & 0.00 & 0.00 & 0.00 & 0.00 & 0.00 & 0.00 & 0.00 & 0.00 & 0.06 & 0.00 \\
\hline Al & 0.12 & 0.08 & 0.08 & 0.08 & 0.05 & 0.06 & 0.07 & 0.08 & 0.04 & 0.07 & 0.10 & 0.07 & 0.08 \\
\hline $\mathbf{P}$ & 0.09 & 0.24 & 0.28 & 0.28 & 0.32 & 0.13 & 0.37 & 0.33 & 0.33 & 0.37 & 0.29 & 0.46 & 0.28 \\
\hline $\mathbf{S}$ & 1.81 & 1.69 & 1.66 & 1.65 & 1.61 & 1.76 & 1.61 & 1.62 & 1.62 & 1.60 & 1.65 & 1.59 & 1.60 \\
\hline Cl & 0.00 & 0.00 & 0.00 & 0.06 & 0.00 & 0.00 & 0.00 & 0.00 & 0.05 & 0.00 & 0.00 & 0.00 & 0.00 \\
\hline $\mathbf{K}$ & 0.83 & 0.73 & 0.78 & 0.78 & 0.75 & 0.72 & 0.76 & 0.76 & 0.73 & 0.69 & 0.74 & 0.69 & 0.57 \\
\hline $\mathrm{Ca}$ & 0.03 & 0.05 & 0.00 & 0.06 & 0.03 & 0.00 & 0.05 & 0.03 & 0.09 & 0.06 & 0.03 & 0.10 & 0.04 \\
\hline $\mathbf{T i}$ & 0.00 & 0.00 & 0.00 & 0.00 & 0.00 & 0.02 & 0.00 & 0.00 & 0.00 & 0.00 & 0.00 & 0.00 & 0.00 \\
\hline $\mathrm{Fe}$ & 2.73 & 2.68 & 2.79 & 2.70 & 2.82 & 2.78 & 2.70 & 2.73 & 2.73 & 2.73 & 2.78 & 2.44 & 2.90 \\
\hline $\mathrm{Na}+\mathrm{K}+2 * \mathrm{Ca}$ & 0.88 & 0.94 & 0.78 & 1.02 & 0.95 & 0.94 & 0.85 & 0.91 & 1.03 & 0.92 & 0.79 & 0.90 & 0.92 \\
\hline
\end{tabular}

kaolinite, or illite-muscovite $\pm \mathrm{Chl} / \mathrm{Sm} \pm \mathrm{I} / \mathrm{Sm}$ are in agreement with the diagenetic-anchizonal grade indicated by KI values.

2. To the west, slates from Yavi (western flank of Sierra de Santa Victoria) depict KI values in the range of high anchizone-epizone $\left(0.30-0.36^{\circ} \Delta 2 \theta\right)$ and rough anastomosing spaced cleavage $\left(\mathrm{S}_{1}\right)$ parallel to the sedimentary layering $\left(\mathrm{S}_{0}\right)$, or a crenulation cleavage $\left(\mathrm{S}_{1}\right)$ oblique to $\mathrm{S}_{0}$. The clay mineral associations identified in these slates (illite-muscovite \pm kaolinite \pm chlorite \pm smectite) do not represent equilibrium assemblages, neither are they consistent with the KI values indicating high anchizone to epizone. Consequently smectite and kaolinite probably represent retrograde-diagenetic products (Nieto et al., 2005).

3. Finally, slates and metavolcanic rocks from Puna show KI values from high anchizone to epizone $\left(0.23-0.35^{\circ} \Delta 2 \theta\right)$. In these slates a discontinuous crenulation cleavage $\left(\mathrm{S}_{1}\right)$ oblique to $\mathrm{S}_{0}$ or an $\mathrm{S}_{1}$ cleavage, mainly sub parallel to the sedimentary layering $\left(\mathrm{S}_{0}\right)$ is observed. Few samples of this group show clay-mineral assemblages comprising illite-muscovite and chlorite, in coherence with the anchizonal/epizonal grade indicated by KI values. On the contrary, most of the samples consist of complex clay-minerals assemblages comprising, in addition to illite-muscovite and rarely chlorite, diverse phyllosilicates like kaolinite, smectite, and various mixed-layers (Chl/Sm, $\mathrm{Chl} / \mathrm{Vrm}$ and $\mathrm{Chl} / \mathrm{Mi})$ that are not stable in the anchizone and neither in the epizone (Merriman and Peacor, 1999). Consequently, these phases could not represent prograde metamorphic phases in these rocks.

In the metadacite from Sierra de Cochinoca-Escaya epitaxial growth of kaolinite on layers of primary muscovite was observed at SEM images (Fig. 5c). Whereas that, the metaandesite from the same outcrop depicts strong evidences of hydrothermal alteration at optical microscope and SEM, such as phenocrysts of albite depicting dissolution voids, embayments filled with mixed-layered phyllosilicates, and replacement by fine-grained white mica (Fig 5d, e). Moreover, mixed-layered phyllosilicates form veinlets, sometimes associated with scarce anhedral quartz exhibiting embayments. Furthermore, in this metaandesite sulfates of the alunite-jarosite family occur in close association with goethite (Fig. 5f). Jarosite is a relatively common mineral in the supergene zones of pyrite-bearing ore deposits. It can also form in saline lakes and playas from aqueous sulfate that is derived from the oxidation of pyrite and transported many kilometers by groundwater (Alpers et al., 1992). On the other hand, hydrothermal, steam-heated jarosite can form from the aqueous sulfate derived from the oxidation of $\mathrm{H}_{2} \mathrm{~S}$ in epithermal environments and hot 
springs commonly associated with volcanism (Rye et al., 1992; Rye and Alpers, $1997^{1}$ ). The textural features of jarosite in the metaandesite, filling amygdules, rimming cavities, forming amoeboidal patches and veinlets, and forming subhedral crystals up to $0.1 \mathrm{~mm}$, suggest a hydrothermal origin. Formation of jarosite requires high ferric iron activities, high sulfate concentrations and low pH (Stoffregen, 1993), consequently the stability field of jarosite is restricted to extremely acidic and oxidizing environments (Stoffregen, 1993; Rye and Alpers, 1997¹). The low $\mathrm{pH}$ necessary to form jarosite is inconsistent with the occurrence of plagioclase in the same rock. Zymbelman et al. (2005) explained the preservation of plagioclase in jarosite-bearing altered volcanic rocks by restricting the low-pH fluids to limited volumes near the sites of jarosite formation, which is consistent with the textures observed in the studied metaandesite.

In natural environments the most significant control on jarosite stability is its reaction to form goethite or hematite (Stoffregen, 1993). In the metaandesite $\mathrm{E} 17$ goethite was identified by $\mathrm{XRD}$, thus the jarosite-oxyhydroxide assemblage should have formed around or below $100{ }^{\circ} \mathrm{C}$, the temperature at which the goethite to hematite transition takes places (Langmuir, 1971). The metavolcanic rocks exposed on Sierra de Cochinoca-Escaya resulted from submarine volcanism related to the Ordovician volcanic arc. Consequently, these textural and mineralogical features should be the result of a hydrothermal activity related with the volcanic arc, subsequent to the maximum burial and the attainment of epizonal metamorphism. In this context, the occurrence of smectite, kaolinite, as well as interstratified Chl/ $\mathrm{Sm}$ and $\mathrm{Chl} / \mathrm{Vrm}$ phases in most of the anchizonal/ epizonal slates of Sierra de Cochinoca-Escaya and Sierra de Rinconada should also be consequence of alteration by hydrothermal fluids related with the volcanic arc; thus they represent retrograde diagenesis products (Nieto et al., 2005). All these retrograde-diagenetic clay-minerals show a texture parallel or sub-parallel to the original metamorphic phyllosilicates. They are the result of epitaxial and/ or topotaxial reactions (e.g., Arostegui et al., 2001), therefore they inherit the same crystallographic orientation of the mother phases (Nieto et al., 1994, 2005); hence a distinction between metamorphic and retrograde phyllosilicates, based only on their orientation is impossible.

The common occurrence of kaolinite in the slates and the metavolcanic rocks of Sierra de CochinocaEscaya studied, coupled with the substitution of chlorite by interstratified lower-temperature phases in most of these rocks also indicate hydrothermal fluids with high $\mathrm{H}^{+}$/cations ratios, producing acid type alteration, at temperatures of between 100 and $\sim 300{ }^{\circ} \mathrm{C}$ (Utada, 1980; Inoue, 1995). Up to now, the only evidences of hydrothermal activity connected with the Ordovician arc mentioned in the literature was the occurrence of several mineralized quartz veins hosted in Ordovician beds in the Sierra de Santa Victoria and Sierra de Cochinoca-Escaya (Craig et al., 1995; Coira et al., 2001). Thus the evidence presented in this work constitute, up to our knowledge, the first report of an extensive hydrothermal activity affecting not only the metavolcanic rocks but also the Lower Ordovician metasediments of northern Puna and the eastern flank of Sierra de Santa Victoria.

\subsection{Chlorite geothermometry}

We have applied the thermodynamic-based geothermometer for di-trioctahedral chlorite proposed by Bourdelle et al. (2013). According to Bourdelle and Cathelineau (2015), and Vidal et al. (2005) recommendations only analyses showing vacancies $>0.1$ a.p.f.u./ $\mathrm{Si}>2.5$ a.p.f.u. and $\mathrm{Na}_{2} \mathrm{O}+\mathrm{K}_{2} \mathrm{O}+\mathrm{CaO}<0.5 \%$ wet were considered for geothermometric calculations. No attempt has been carried out to differentiate among detrital, transformed and neo-formed chlorites, as the crenulation cleavage tends to be sub parallel to the sedimentary layering. According to Giorgetti et al. (1997), the interleaved phyllosilicate grains (frequently named stacks), as those recognizable in figures $3 \mathrm{c}$ or $4 \mathrm{c}$ represent former detrital grains, transformed during the diagenetic-metamorphic evolution, they inherit the original space of the clast, but new minerals growth during the prograde and retrograde evolution. The results for the three chlorite-bearing samples are shown in figure 9.

Geothermometric calculations yield temperatures from 124 to $199^{\circ} \mathrm{C}$ for the mudstone $\mathrm{N} 4$ from Nazareno, Eastern Cordillera $\left(\mathrm{n}=6\right.$, average $\left.138^{\circ} \mathrm{C}\right)$ and values in the range from 179 to $339^{\circ} \mathrm{C}(\mathrm{n}=18$, 


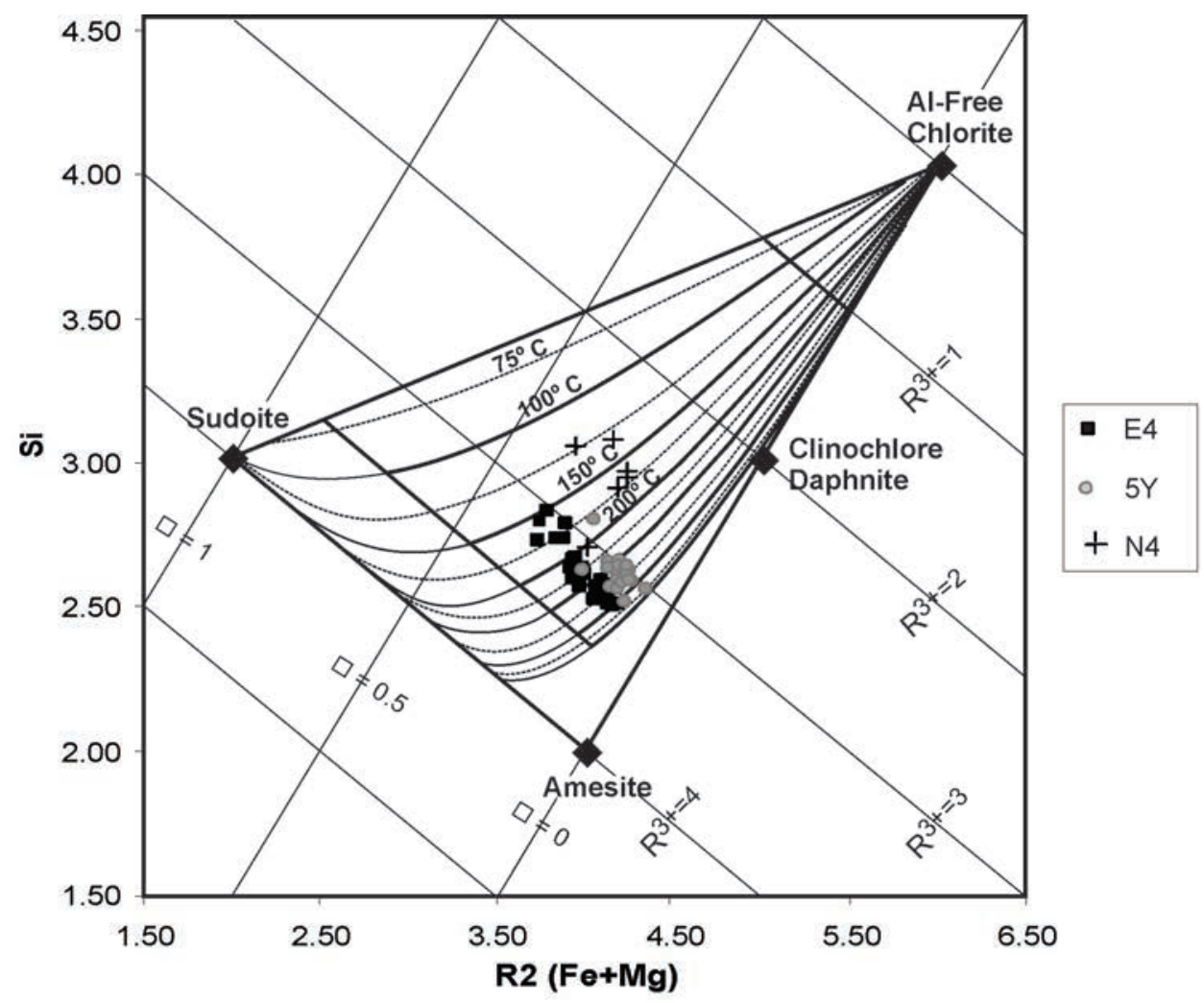

FIG. 9. Temperatures obtained for the three chlorite-bearing samples with the geothermometer for di-trioctahedral chlorite proposed by Bourdelle et al. (2013) represented in the T-Si- $\mathrm{R}^{2+}$ diagram (Bourdelle and Cathelineau, 2015). Isotherms (in $50{ }^{\circ} \mathrm{C}$ steps for solid lines) and specific-composition temperatures are represented.

average $273{ }^{\circ} \mathrm{C}$ ) for the slate $\mathrm{Y} 5$ from Yavi. On the other hand, a wide range of temperatures from 151 to $322{ }^{\circ} \mathrm{C}\left(\mathrm{n}=28\right.$, average $\left.231^{\circ} \mathrm{C}\right)$ were obtained for chlorites from slate E4 of northern Puna.

However, geothermometric calculations could not be accomplished for $\sim 10 \%$ of chlorite analyses of $E 4$ and $~ 50 \%$ of chlorite analyses of Y 5 , enclosed in the vacancies $<0.1$ a.p.f.u. $/ \mathrm{Si}<2.5$ a.p.f.u. window, that according to Bourdelle and Cathelineau (2015) are outside the T range of applicability of Bourdelle's thermometer, and thus probably formed at $\mathrm{T}>350{ }^{\circ} \mathrm{C}$.

\subsection{Phengite geobarometry}

The compositional variation of dioctahedral micas through the Tschermak's (or phengitic) vector is mainly controlled by pressure of formation (Velde 1965, 1967). Based on this correlation, Massone and Schreyer (1987) proposed a Si isopleths grid to estimate pressure of formation of metamorphic dioctahedral micas for rocks containing the limiting paragenesis Ms-KFsp-Qz-Phl. We have obtained more than 100 analyses of dioctahedral micas from the five metapelites analysed; even though, Si contents of K-white mica of samples from Nazareno and Puna could not be employed for geobarometric estimations. In the first case, because the temperatures obtained by chlorite geothermometry are below the range of application of the Massone and Schreyer's grid, and in the other case because textures and clay mineral associations evidenced a strong retrograde overprint.

On the other hand, the two slates from Yavi show clay mineral associations that do not represent equilibrium assemblages and that are also inconsistent with the KI values indicating high anchizone. However, the retrograde overprint of the Ordovician rocks from the western flank of Santa Victoria Range is less strong than in the outcrops from Puna. 
Therefore, we have chosen the slates from Yavi for geobarometric purposes, taking also into account that one of the samples contains the limiting paragenesis Ms-KFsp-Qz-Phl, with chlorite in place of phlogopite as ferromagnesian phase. Dioctahedral micas that evidenced interlayer charge $<0.85$ were not considered for the geobarometric estimation to avoid drastic effects of illitic substitution, which also produce excess Si. Furthermore, analyses showing (Si-3) values higher than $\mathrm{Mg}+\mathrm{Fe}$ contents were also excluded, as they deviate from ideal Tschermak's substitution. Thus, the Si content of dioctahedral micas from the two slates from Yavi varies between 2.99 and 3.39, with an average of 3.13. Using the recalculated $\mathrm{Si}$ isopleths grid published by Massone and Szpurka (1997), and considering the maximum temperatures calculated by chlorite geothermometry for the slate Y5 $\left(300-350{ }^{\circ} \mathrm{C}\right)$, values between $\sim 1.9$ to $\sim 2.9 \mathrm{kbar}$ can be estimated for the Ordovician successions in the western flank of Santa Victoria Range.

\subsection{Interpretation of the paleotemperatures indicated by inorganic indices}

The wide range of temperatures obtained applying the chlorite geothermometer for the slate from northern Sierra de Cochinoca-Escaya $\left(128-322^{\circ} \mathrm{C}\right)$, as well as the low average computed $\left(228^{\circ} \mathrm{C}\right)$, are in discrepancy with the high anchizone-epizone KI values obtained for the slates of this area. Nevertheless, their maximum values $\left(>300^{\circ} \mathrm{C}\right)$, together with those abundant analyses to which the application of chlorite geothermometry is not recommended due to results above $350^{\circ} \mathrm{C}$ (see below) are well in agreement with such KI values. Therefore, the overall range of chlorite compositions should represent the sum of those formed both at temperatures near the metamorphic peak and the widespread low-temperature hydrothermal alteration. Vidal et al. (2006, 2016 and references therein) presented maps in which chlorites of different composition crystallized at different temperatures and times of the diagenetic-metamorphic evolution; they are often observed to metastably coexist in different microstructural sites of the same rock. In such case, the definition of a single temperature and pressure is impossible and it cannot be restricted to the peak temperature condition (Vidal et al., 2016).

On the other side, the average temperature obtained for the slate from the western flank of Sierra de Santa Victoria $\left(273{ }^{\circ} \mathrm{C}\right)$ is in agreement with the KI values corresponding to high anchizone. Furthermore, this slate depicts a narrower range of values $\left(179-339^{\circ} \mathrm{C}\right)$. Geothermometric calculations yields lower average temperatures $\left(161{ }^{\circ} \mathrm{C}\right)$ for the mudstone from the eastern flank of Sierra de Santa Victoria (N4, Nazareno) than for the slate from Yavi $\left(250.5^{\circ} \mathrm{C}\right)$, located to the west, in agreement with the trend depicted by KI values.

Notwithstanding, the temperatures obtained for slates from northern Puna and Cordón de los Siete Hermanos (Yavi) should be considered minimum values for each area, as $\sim 10 \%$ of chlorite analyses of E4 and half of chlorite analyses of Y5 could not be employed in a quantitative way for geothermometric calculations because they are outside the $T$ range of applicability of Bourdelle's thermometer, but indicates $\mathrm{T}>350{ }^{\circ} \mathrm{C}$ (Bourdelle and Cathelineau, 2015).

The E-W trend showed by KI values from diagenesis/low anchizone in the eastern flank of Sierra de Santa Victoria, to high anchizone/epizone in the Puna, with intermediate values at Yavi, in conjunction with the development of a slaty cleavage in the Ordovician rocks from Yavi, Sierra de Cochinoca-Escaya and western localities coincide with the limits proposed by Hongn (1992) for its "Ocloyic deformation belt". These results are also in agreement with previous studies that identified a belt of maximum deformation affecting the Magmaticsedimentary Cochinoca-Escaya Complex (Mon and Hongn, 1991; Coira et al., 2001).

The pressure of formation of metamorphic dioctahedral micas using the $\mathrm{Si}$ isopleths grid proposed by Massone and Schreyer (1987) could only be estimated for one slate from Yavi. The obtained values between $\sim 1.9$ to $\sim 2.9 \mathrm{kbar}$ indicate an intermediate geothermal gradient of $30-35{ }^{\circ} \mathrm{C} / \mathrm{km}$ for the Ordovician successions in the western flank of Santa Victoria Range, which is typical for mature passive margins of foreland basins (e.g., Allen and Allen, 2005).

\subsection{Temperatures inferred from inorganic indices versus conodont paleothermometry}

The small amount of organic matter that conodonts include in their histology, consisting mainly of apatite like lamellae, gradually change color from amber to brown to black as the carbon is set within the temperature range $50{ }^{\circ} \mathrm{C}$ to $300{ }^{\circ} \mathrm{C}$. At 
higher temperatures $\left(400{ }^{\circ} \mathrm{C}-600{ }^{\circ} \mathrm{C}\right)$, coal burning gradually and progressively decomposes apatite fabric, resulting in color changes from black to gray to white, and finally hyaline, before the conodont is destroyed completely. Conodonts, therefore, can indicate the minimum and maximum temperatures reached by the rocks that contain them through a color alteration index (CAI) suitable for a wide temperature range $\left(50{ }^{\circ} \mathrm{C}-600^{\circ} \mathrm{C}\right)$. These temperatures are mainly related to the depth and duration of the burial of the rocks, and geothermal gradients (Epstein et al., 1977; Rejebian et al., 1987). It is worth noting that in contrast to inorganic indexes of burial temperatures, organic proxies, like CAI, are not affected by retrograde reactions.

The temperatures estimated through inorganic indices for the eastern flank of Sierra de Santa Victoria coincide with those indicated by conodonts from the Rupasca Formation at Nazareno (Manca et al., 1995; Giuliano et al., 2013a) and the Santa Rosita (Voldman et al., 2013) and Acoite formations (Voldman et al., 2016) at Santa Victoria, with CAI 3 (110-200 ${ }^{\circ} \mathrm{C}$, Epstein et al., 1977). Moreover, conodonts have no traces of deformation or metamorphic alteration, according to the illustrations of Rejebian et al. (1987) and later authors. Consequently, they reflect a single sedimentary burial history. Conodonts with CAI 3 were also documented in Lower Ordovician exposures in other localities of Cordillera Oriental, such as in Parcha-Incahuasi (Rao and Tortello, 1996; Ortega and Albanesi, 2005), Purmamarca (Zeballo et al., 2008), Quebrada de Humahuaca (Albanesi and Aceñolaza, 2005) and the Alfarcito Range (Zeballo and Albanesi, 2013). However, conodont studies in various localities of the western margin of the Cordillera Oriental; for example, in the area of El Angosto del Moreno (Moya and Albanesi, 2000), Angosto de la Quesera (Carlorosi et al., 2011), Los Colorados Range (Carlorosi et al., 2013), Altos de Lipán (Albanesi et al., 2014) and Cieneguillas (Rao et al., 1995), reveal background paleotemperatures equivalent to CAI 2-3; slightly lower than those recorded in the above mentioned localities.

Unfortunately, the stratigraphic sections sampled for conodonts in the transitional area from the Cordillera Oriental to the Puna region at Yavi and Cochinoca-Escaya and Rinconada ranges of the Puna, were barren of these microfossils for CAI analyses. The only available isolated records of conodont CAI for the Puna are those from the Lari section, in the Salar del Rincón area of western Puna, which correspond to the Cordylodus lindstromi Zone of the upper Cambrian (Giuliano et al., 2013b). These conodont elements exhibit a state of moderate preservation with dark-brown to black color alteration, corresponding to CAI 4-5. These values indicate attainment of anchizone to epizone, coinciding with the burial temperatures estimated by inorganic indices in this work.

\section{Conclusions}

XRD-based studies of metapelitic and metavolcanic rocks supplemented by textural studies under the SEM let outline the thermal post depositional evolution of the Ordovician successions of north-western Argentina and identified evidences of retrograde reactions. The paleotemperatures obtained with the chlorite geothermometer (Bourdelle et al., 2013), in coincidence with KI values, showed an E-W trend from diagenesis/low anchizone in the eastern flank of Sierra de Santa Victoria, to high anchizone/ epizone in the Puna, with intermediate values in the western flank of Sierra de Santa Victoria. This trend, in conjunction with the development of a slaty cleavage in the Ordovician rocks from Yavi, Sierra de Cochinoca-Escaya and western localities coincide with the limits proposed by Hongn (1992) for its "Ocloyic deformation belt".

The common occurrence of kaolinite in the slates and the metavolcanic rocks of Sierra de CochinocaEscaya studied, coupled with the substitution of chlorite by interstratified lower-temperature phases in most of these rocks and the occurrence of jarosite in a metadacite, indicate hydrothermal fluids with high $\mathrm{H}^{+} /$cations ratios, producing acid type alteration, at temperatures between 100 and $\sim 300{ }^{\circ} \mathrm{C}$ (Utada, 1980; Inoue, 1995). The hydrothermal alteration should have been subsequent to the maximum burial and the attainment of epizonal metamorphism, and was probably related with the posthumous activity of the Ordovician volcanic arc. The widespread occurrence of retrograde diagenesis products (smectite, kaolinite, as well as interstratified $\mathrm{Chl} / \mathrm{Sm}$ and $\mathrm{Chl} /$ Vrm phases) in the anchizonal/epizonal slates of Sierra de Cochinoca-Escaya and Sierra de Rinconada constitute, up to our knowledge, the first report of an extensive hydrothermal activity affecting not only the volcanic rocks but also the Lower Ordovician sediments of northern Puna. 


\section{Acknowledgements}

The help of I. Guerra with the SEM (Centro de Instrumentación Científica, Universidad de Granada, España) was essential for the present work. A. Baleirón prepared the samples for X Ray diffraction, and G. Giordanengo helped with the digital figures. The authors would like to acknowledge the use of the diffractometers from Departamento de Físico-Química, Universidad Nacional de Córdoba, Argentina, and Departamento de Mineralogía y Petrología, Universidad de Granada. The critical reviews and suggestions of the two anonymous reviewers have improved the quality of the paper. This work was financed by ANPCyT - PICT 2008-1797 grant (Argentina), Research Project CGL2011-30153 (Spanish Ministry of Science), and the Research Group RNM-0179 of the Junta de Andalucía, Spain. The stay of M. Do Campo at the Universidad de Granada was supported by and AUIP grant (Programa de Movilidad Académica de Postgrado).

\section{References}

Albanesi, G.L.; Aceñolaza, G.F. 2005. Conodontes de la Formación Rupasca (Ordovícico Inferior) en el Angosto de Chucalezna, Cordillera Oriental de Jujuy: Nuevos elementos bioestratigráficos para una localidad clásica del noroeste argentino. Ameghiniana 42 (2): 295-310.

Albanesi, G.L.; Ortega, G.; Zeballo, F.J. 2008. Faunas de conodontes y graptolitos del Paleozoico inferior en la Cordillera Oriental Argentina. In Geología y Recursos Naturales de la Provincia de Jujuy (Coira, B.; Zappettini, E.O.; editors). Congreso Geológico Argentino, No. 17, Relatorio: 98-118. San Salvador de Jujuy.

Albanesi, G.L.; Ortega, G.; Monaldi, C.R. 2014. Precisiones sobre la edad de la Formación Cieneguillas (Ordovícico) en la cuesta de Lipán, Cordillera Oriental de Jujuy. In Congreso Geológico Argentino, No. 19, Actas, CD-ROM. Córdoba.

Albanesi, G.L.; Giuliano, M.E.; Pacheco, F.; Ortega, G.; Monaldi, C.R. 2015. Conodonts from the CambrianOrdovician boundary in the Cordillera Oriental, NW Argentina. Stratigraphy 12 (3-4): 1-21.

Allen, P.A.; Allen, J.R. 2005. Basin analysis. Principles and Applications. Blackwell Scientific Publications, Oxford: 1-549.

Alpers, C.N.; Rye, R.O.; Nordstrom, D.K.; White, L.D.; King, B.S. 1992. Chemical, crystallographic and stable isotope propertiesof alunite and jarosite from acidhypersaline lakes. Chemical Geology 96: 203-226.

Arostegui, J.; Irabien, M.J.; Nieto, F.; Sanguesa, J.; Zuluaga, M.C. 2001. Microtextures and the origin of muscovite-kaolinite intergrowths in sandstones of the Utrillas Formation, Basque Cantabrian Basin, Spain. Clays and Clay Minerals 49: 529-539.

Astini, R. 2003. The Ordovician proto-Andean basins. In Ordovician Fossils of Argentina (Benedetto, J.L.; editor), Universidad Nacional de Córdoba, Secretaría de Ciencia y Tecnología: 1-74.

Astini, R.A. 2008. Sedimentación, facies, discordancias y evolución paleoambiental durante el CámbricoOrdovícico. In Geología y Recursos Naturales de la Provincia de Jujuy (Coira, B.; Zappettini, E.O.; editors). Congreso Geológico Argentino, No. 17, Relatorio: 50-73. San Salvadora de Jujuy.

Bahlburg, H. 1990. The Ordovician basin in the Puna of NW Argentina and N Chile: geodynamic evolution from back-arc to foreland basin. Geotektonische Forschungen 75: 1-107.

Bahlburg, G.; Breitkreuz, C. 1991.The evolution of marginal basins in the southern Central Andes of Argentina and Chile during the Paleozoic. Journal of South American Earth Sciences 4: 171-188.

Bahlburg, H.; Hervé, E. 1997.Geodynamic evolution and tectonostratigraphic terranes of northwestern Argentina and northern Chile. Geological Society of America, Bulletin 109: 869-884.

Bourdelle, F.; Cathelineau, M. 2015. Low-temperature chlorite geothermometry: a graphical representation based on a $T-\mathrm{R}^{2+}-\mathrm{Si}$ diagram. European Journal of Mineralogy 27: 617-626.

Bourdelle, F.; Parra, T.; Chopin, C.; Beysacc, O. 2013. A new chlorite geothermometer for diagenetic to low-grade metamorphic conditions. Contributions to Mineralogy and Petrology 165: 723-735.

Buatois, L.A.; Mángano, M.G. 2003. Sedimentary facies and depositional evolution of the Upper Cambrian to Lower Ordovician Santa Rosita Formation in northwest Argentina. Journal of South American Earth Sciences 16: 343-363.

Buatois, L.A.; Zeballo, F.J.; Albanesi, G.; Ortega, G.; Vaccari, E.; Mángano, G. 2006. Depositional environments and stratigraphy of the Upper Cambrian-Lower Ordovician Santa Rosita Formation at the Alfarcito area, Cordillera Oriental, Argentina: integration of biostratigraphic data within a sequence stratigraphic framework. Latin American Journal of Sedimentology and Basin Analysis 13: 1-29.

Carlorosi, J.; Heredia, S.; Aceñolaza, G. 2011. Ordovician conodonts of the Devendeus Formation at the Angosto de La Quesera (Cordillera Oriental of Salta, Argentina): Taxonomic considerations and biostrati- 
graphic significance. Geologica Acta 9 (2): 187-197. doi: 10.1344/105.000001691.

Carlorosi, J.; Heredia, S.; Aceñolaza, G. 2013. Middle Ordovician (early Dapingian) conodonts in the Central Andean Basin of NW Argentina. Alcheringa 37: 1-12.

Cathelineau, M. 1988. Cation site occupancy in chlorites and illites as a function of temperature. Clay Minerals 23: 471-485.

Coira, B. 1996. Volcanismo submarino silíceo ordovícico en la Puna nororiental $\left(22^{\circ}-24^{\circ} \mathrm{S}, 65^{\circ} 45^{\prime}-66^{\circ} 45^{\prime} \mathrm{O}\right)$, Argentina. In Congreso Geológico de Bolivia, No. 12, Memorias 3: 1003-1009. Tarija.

Coira, B.; Koukharsky, M. 1991. Lavas en almohadilla ordovícicas en el Cordón de Escaya, Puna Septentrional, Argentina. In Congreso Geológico Chileno, No. 6, Actas 1: 674-678. Viña del Mar.

Coira, B.; Koukharsky, M. 1994. Complejos submarinos dómico-lávicos silíceos de edad ordovícica en el Sector Oriental de la Puna Jujueña $\left(22^{\circ}-23^{\circ} 45^{\prime} \mathrm{S}\right)$, sus implicancias. In Congreso Geológico Chileno, No 7, Actas 2: 1000-1004. Concepción.

Coira, B.; Kay, S.M.; Pérez, B.; Woll, B.; Hanning, M.; Flores, P. 1999. Magmatic sources and tectonic setting of Gondwana margin Ordovician magmas, northern Puna of Argentina and Chile. In Laurentia-Gondwana Connections before Pangea (Ramos, V.A.; Keppie, J.D.; editors). Geological Society of America, Special Paper 336: 145-170.

Coira, B.; Caffe, P.; Ramírez, A.; Chayle, W.; Díaz, A.; Rosas, S.; Pérez, A.; Pérez, B.; Orozco, O.; Martínez, M. 2001. Hoja Geológica 2366-I/2166-III "Mina Pirquitas", Provincia de Jujuy. Servicio Geológico Minero Argentino, Instituto de Geología y Recursos Minerales, Boletín 269: 123 p. Buenos Aires.

Coira, B.; Kirschbaum, A.; Hongn, F.; Pérez, B.; Menegatti, N. 2009. Basic magmatism in northeastern Puna, Argentina: Chemical composition and tectonic setting in the Ordovician back-arc. Journal of South American Earth Sciences 28: 374-382.

Craig, J.R.; Segal, S.J.; Zappettini, E.O. 1995. El distrito aurífero Rinconada, Provincia de Jujuy, República Argentina. In Congreso Latinoamericano de Geología, No. 10, Actas 2: 22-35. Caracas.

De Caritat, P.; Hutcheon, I.; Walshe, J.L. 1993. Chlorite Geothermometry: A Review. Clays and Clay Minerals 41 (2): 219-239.

De Ros, L.F. 1998. Heterogeneous generation and evolution of diagenetic quartzarenites in the Silurian-Devonian Fumas Formation of the Parana Basin, southern Brazil. Sedimentary Geology 116: 99-128.
Do Campo, M.; Nieto, F. 2005. Origin of mixed-layered (R1) muscovite-chlorite in an anchizonal slate from Puncoviscana Formation (Salta Province, Argentina). Clay Minerals 40 (3): 317-332. doi:10.1180/0009855054030176.

Do Campo, M.; Collo, G.; Nieto, F. 2013. Geothermobarometry of very low-grade metamorphic pelites of the Vendian-Early Cambrian Puncoviscana Formation (NW Argentina). European Journal of Mineralogy 25: 429-451.

Epstein, A.G.; Epstein, J.B.; Harris, L.D. 1977. Conodont color alteration. An index to organic metamorphism. United States Geological Survey, Professional Paper 995: $27 \mathrm{p}$.

Giorgetti, G.; Memmi, I.; Nieto, F. 1997. Microstructures of intergrown phyllosilicate grains from Verrucano metasediments (northern Apennines, Italy). Contributions to Mineralogy and Petrology 128: 127-138.

Giuliano, M.E.; Albanesi, G.L.; Ortega, G.; Zeballo, F.J.; Monaldi, C.R. 2013a. Conodonts and graptolites of the Santa Rosita Formation (Tremadocian) at the Nazareno area, Santa Victoria Range, Cordillera Oriental of Salta, Argentina. In Conodonts from the Andes (Albanesi, G.L.; Ortega, G.; editors). Paleontological Note, Special Publicarion 13: 39-44. Buenos Aires.

Giuliano, M.E.; Ortega, G.; Albanesi, G.L.; Monaldi,C.R. 2013b. Late Cambrian-Early Tremadocian conodont and graptolite records from the El Médano section, Salar del Rincón, Puna of Salta, Argentina. In Conodonts from the Andes (Albanesi, G.L.; Ortega, G.; editors). Paleontological Note, Special Publication 13: 33-38. Buenos Aires.

Guidotti, C.V. 1984. Micas in Metamorphic Rocks. In Micas (Bailey, S.W.; editor). Mineralogical Society of America, Reviews in Mineralogy 13: 357-467. Washington.

Guidotti, C.V.; Yates, M.G.; Dyar, M.D.; Taylor, M.E. 1994a. Petrogenetic implications of the $\mathrm{Fe}^{+3}$ content of muscovite in pelitic schists. American Mineralogist 79: 793-795.

Guidotti, C.V.; Sassi, F.P.; Blencoe, J.G.; Selverstone, J. 1994b. The paragonite-muscovite solvus: I. P-T-X limits derived from the Na-K compositions of natural, quasi binary paragonite-muscovite pairs. Geochimica and Cosmochimica, Acta 58: 2269-2275.

Gutiérrez-Marco, J.C.; Aceñolaza, G.F.; Esteban, S.B. 1996. Revisión de algunas localidades con graptolitos ordovícicos en la Puna salto-jujeña (noroeste de 
Argentina). In Congreso Geológico de Bolivia, No. 12, Memorias 2: 725-731. Tarija.

Hillier, S.; Velde, B. 1991. Octahedral occupancy and chemical composition of diagenetic (low-temperature) chlorites. Clay Minerals 26 (2): 149-168. doi: 10.1180/ claymin.1991.026.2.01.

Hongn, F.D. 1992. Tectónica y microtectónica del basamento pre devónico de la Puna. Tesis doctoral (Inédito),Universidad Nacional de Salta: 228 p.

Hongn, F.D.; Vaccari, E. 2008. La discordancia Tremadociano superior-Arenigiano inferior en Vega Pinato (Salta): Evidencia de deformación intraordovícica en el borde occidental de la Puna. In Congreso Geológico Argentino, No. 17, Actas 3: 1299-1300. San Salvador de Jujuy.

Inoue, A. 1995. Formation of Clay Mineralsin Hydrothermal Environments. In Origin and Mineralogy of Clays (Velde, B.; editor). Springer-Verlag: 268-329. Berlin-Heidelberg.

Jacobshagen, V.; Müller, J.; Wemmer, K.; Ahrendt, H.; Manutsoglu, E. 2002.Hercynian deformation and metamorphism in the Cordillera Oriental of Southern Bolivia, Central Andes. Tectonophysics 345: 119-130.

Jowett, E.C. 1991. Fitting iron and magnesium into the hydrothermal chlorite geothermometer. GAC/MAC/ SEG Joint Annual Meeting. Program with Abstracts, 16: A62. Toronto.

Kley, J.; Reinhardt, M. 1994.Geothermal and tectonic evolution of the Eastern Cordillera and the Subandean Ranges of Southern Bolivia. In Tectonics of the Southern Central Andes. Structure and Evolution of an Active Continental Margin (Reutter, K.J.; Scheuber, E.; Wigger, P.J.; editors). Springer Verlag: 155-170.

Langmuir, D. 1971. Particle size effect on the reaction goethite $=$ hematite + water. American Journal of Science 271: 147-156.

Lanari, P.; Wagner, T.; Vidal, O. 2014. A thermodynamic model for di-trioctahedral chlorite from experimental and natural data in the system $\mathrm{MgO}-\mathrm{FeO}-\mathrm{Al}_{2} \mathrm{O}_{3}-\mathrm{SiO}_{2}-$ $\mathrm{H}_{2} \mathrm{O}$ : applications to P-T sections and geothermometry. Contributions to Mineralogy and Petrology: 167-968. doi: 10.1007/s00410-014-0968-8.

López Munguira, A.; Nieto, F.; Morata, D. 2002. Chlorite composition and geothermometry: a comparative HRTEM/AEM-EMPA-XRD study of Cambrian basic lavas from the Ossa Morena Zone, SW Spain. Clay Minerals 37 (2): 267-281.

Manca, N.; Heredia, S.; Hünicken, M.; Rubinstein, C. 1995. Macrofauna, conodontes y acritarcos de la Formación Santa Rosita (Tremadociano), Nazareno, provincia de
Salta, Argentina. Boletín de la Academia Nacional de Ciencias 60: 267-276. Córdoba.

Massonne, H.J.; Schreyer, W. 1987. Phengite geobarometry based on the limiting assemblage with K-feldspar, pholgopite and quartz. Contributions to Mineralogy and Petrology 96: 212-224.

Massone, H.J.; Szpurka, Z. 1997.Thermodynamic properties of white micas on the basis of high-pressure experiments in the systems $\mathrm{K}_{2} \mathrm{O}-\mathrm{MgO}-\mathrm{Al}_{2} \mathrm{O}_{3}$ $\mathrm{SiO}_{2}-\mathrm{H}_{2} \mathrm{O}$ and $\mathrm{K}_{2} \mathrm{O}-\mathrm{FeO}-\mathrm{Al}_{2} \mathrm{O}_{3}-\mathrm{SiO}_{2}-\mathrm{H}_{2} \mathrm{O}$. Lithos 41: 229-250.

Méndez, V.; Navarini, A.; Plaza, D.; Viera, O. 1973. Faja Eruptiva de la Puna Oriental. In Congreso Geológico Argentino, No. 5, Actas 4: 147-158. Buenos Aires.

Merriman, R.J.; Peacor, D.R. 1999. Very low-grade metapelites: mineralogy microfabrics and measuring reaction progress. In Low-grade metamorphism (Frey, M.; Robinson, D.; editors). Blackwell Science: 10-60. Oxford.

Mon, R.; Hongn, F.D. 1991. The structure of the Precambrian and Lower Paleozoic basement of the Central Andes between $22^{\circ}$ and $32^{\circ} \mathrm{S}$. Lat. Geologische Rundschau 80: 745-758.

Mon, R.; Salfity, J.A. 1995.Tectonic evolution of the Andes of Northern Argentina. In Petroleum Basins of South America (Tankard, A.J.; Suárez, R.; Welsink, H.J.; editors). American Association of Petroleum Geology, Memoir 62: 269-283.

Moore, D.M.; Reynolds, R.C. 1997. X-Ray diffraction and the identification and analysis of clay minerals. Oxford University Press: 378 p. New York.

Moya, M.C. 1999. El Ordovícico en los Andes del norte argentino. In Geología del Noroeste Argentino (González Bonorino, G.; Omarini, R.; Viramonte, J.; editors). Congreso Geológico Argentino, No. 14, Relatorio I: 134-152. Salta.

Moya, M.C. 2003. The Ordovician System in the Argentine Eastern Cordillera. In Ordovician and Silurian of the Cordillera Oriental and Sierras Subandinas, NW Argentina. Field Trip Guide. Instituto Superior de Correlación Geológica (INSUGEO), Serie Correlación Geológica 11: 7-16. Tucumán.

Moya, M.C. 2015. La "Fase Oclóyica" (Ordovícico Superior) en el noroeste argentino. Interpretación histórica y evidencias en contrario. Instituto Superior de Correlación Geológica (INSUGEO), Serie Correlación Geológica 31 (1): 73 - 110.

Moya, M.C.; Albanesi, G.L. 2000. New stratigraphic section to define the Cambrian-Ordovician boundary in Eastern Cordillera, Northwest Argentina. In Cambrian 
from the southern edge (Aceñolaza, G.F.; Peralta, S.; editors). Instituto Superior de Correlación Geológica (INSUGEO), Miscelánea 6: 114-116. Tucumán.

Nieto, F.; Velilla, N.; Peacor, D.R.; Ortega Huertas, M. 1994. Regional retrograde alteration of sub-greenschist facies chlorite to smectite. Contributions to Mineralogy and Petrology 115: 243-252.

Nieto, F.; Mata, M.P.; Bauluz, B.; Giorgetti, G.; Árkai, P.; Peacor, D.R. 2005. Retrograde diagenesis, awidespread process on a regional scale. Clay Minerals 40 (1): 93-104.

Ortega, G.; Albanesi, G.L. 2005. Tremadocian graptoliteconodont biostratigraphy of the South American Gondwana margin (Eastern Cordillera, NW Argentina). In Ordovician revisited: Reconstructing a unique period in Earth History (Aceñolaza, G.F.; editor). Geologica Acta 3 (4): 355-372. Barcelona.

Ramos, V.A. 1999. Evolución tectónica de la Argentina. In Geología Argentina (Caminos, R.; editor). Instituto de Geología y Recursos Minerales, Servicio Geológico Minero Argentino (SEGEMAR), Anales 29: 715-784.

Rao, R.I.; Tortello, F. 1996. Tremadoc conodonts and trilobites from the Cardonal Formation, Incamayo Creek, Salta Province, northwestern Argentina. Palaeontología Polónica 58: 31-45.

Rejebian, V.A.; Harris, A.G.; Huebner, J.S. 1987. Conodont color and textural alteration; An index to regional metamorphism, contact metamorphism, and hydrothermal alteration. Geological Society of America Bulletin 99 (4): 471-479.

Rubiolo, D.; Seggiaro, R.; Gallardo, E.; Disalvo, A.; Sánchez, M.; Turel, A.; Ramallo, E.; Sandruss, A.; Godeas, M. 2001. Hoja Geológica 2366-II/2166-IV, La Quiaca. Geología y Provincias de Jujuy y Salta. Instituto de Recursos Minerales, Servicio Geológico Minero Argentino, Boletín: 246 p. Buenos Aires.

Rye, R.O.; Bethke, P.M.; Wasserman, M.D. 1992. The stable isotopegeochemistry of acid sulfate alteration. Economic Geology 87: 225-262.

Stoffregen, 1993. Stability relations of jarosite and natrojarosite at $150-250^{\circ} \mathrm{C}$. Geochimica and Cosmochimica, Acta 57: 2417-2429.

Tawackoli, S.; Kley, J.; Jacobshagen, V. 1996. Evolución tectónica de la Cordillera Oriental del sur de Bolivia. In Congreso Geológico de Bolivia, No. 12, Memorias I: 91-96. Tarija.

Toro, B.; Meroi Arcerito, F.; Muñoz, D.; Waisfeld, B.; De La Puente, G. 2015. Graptolite-trilobite biostratigraphy in the Santa Victoria area, Northwestern Argentina.
A key for regional and worldwide correlation of the Lower Ordovician (Tremadocian-Floian). Ameghiniana 52 (5): 535-557.

Turner, J.C. 1960. Estratigrafía de la Sierra de Santa Victoria y adyacencias. Boletín Academia Nacional de Ciencias 41: 163-196. Buenos Aires.

Turner, J.C.M. 1964. Descripción Geológica de la Hoja 2c. Santa Victoria (Provincias de Salta y Jujuy). Instituto Nacional de Geología y Minería, Boletín 104: 99 p. Buenos Aires.

Turner, J.C.M.; Méndez, V. 1975. Geología del sector oriental de los Departamentos de Santa Victoria e Iruya, Provincia de Salta, República Argentina. Boletín de la Academia Nacional de Ciencias 51 (1-2): 11-24. Córdoba.

Turner, J.C.M.; Mon, R. 1979. Cordillera Oriental. In Geología Regional Argentina (Turner, J.C.M.; editor). Academia Nacional de Ciencias, Publicación Especial 1: 57-94.Córdoba.

Utada, M. 1980. Hydrothermal alteration related to igneous acidity in Cretaceous and Neogene formations of Japan. Mining Geology Japanese, Special Issue 8: 67-83.

Velde, B. 1965. Phengite micas: Synthesis, stability, and natural occurrence. American Journal of Science 263: 886-913.

Velde, B. 1967. $\mathrm{Si}^{+4}$ content of natural phengites. Contributions to Mineralogy and Petrology 14: 250-258.

Vento, B.A. 2013. Cuantificación de las relaciones taxonómicas, filogenéticas y de los patrones paleoecológicos de los graptolitos del Paleozoico inferior del noroeste de Argentina. Tesis Doctoral (Inédito), Universidad Nacional de Cuyo: 333 p.

Vidal, O.; Parra, T.; Vieillard, Ph. 2005. Thermodynamic properties of the Tschermak solid solution in Fechlorites: application to natural examples and possible role of oxidation. American Mineralogist 90: 347-358.

Vidal, O.; De Andrade, V.; Lewin, E.; Munoz, M.; Parra, T.; Pascarelli, S. 2006. P-T-deformation- $\mathrm{Fe}^{3+} / \mathrm{Fe}^{2+}$ mapping at the thin section scale and comparison with XANES mapping: application to a garnet-bearing metapelite from the Sambagawa metamorphic belt (Japan). Journal of Metamorphic Geology 24: 669-683.

Vidal, O.; Lanari, P.; Munoz, M.; Bourdelle, F.; de Andrade, V. 2016. Deciphering temperature, pressure, oxygen activity conditions of chlorite formation. Clay Minerals 51 (4): 615-633. doi: 10.1180/clay$\min .2016 .051 .4 .06$.

Voldman, G.G.; Albanesi, G.L.; Monaldi, C.R.; Zeballo, F. 2013. Biostratigraphy of the Santa Rosita Formation (Furongian-Tremadocian) in its type area, Eastern 
Cordillera, NW Argentina. Stratigraphy 10 (4): 301-322.

Voldman, G.G.; Albanesi, G.L.; Ortega, G.; Giuliano, M.E.; Monaldi, C.R. 2016. New conodont taxa and biozones from the Lower Ordovician of the Cordillera Oriental, NW Argentina. Geological Journal 52: 394-414. doi: 10.1002/gj.2766.

Warr, L.N.; Rice, A.H.N. 1994. Interlaboratory standardization and calibration of clay mineral cristallinity and cristallite size data. Journal of Metamorphic Geology, 12: 141-152.

Warr, L.N.; Ferreiro Mählmann, R. 2015. Recommendations for Kübler Index standardization. Clay Minerals 50 (3): 282-285. doi: 10.1180/claymin.2015.050.3.02.

Whitney, D.L.; Evans, B.W. 2010. Abbreviations for names of rock-forming minerals. American Mineralogist 95: 185-187.

Wiewiora, A.; Weiss, Z. 1990. Crystallochemical classifications of phyllosilicates based on the unified system of projection of chemical composition: II The chlorite group. Clay Minerals 25: 83-92.

Zeballo, F.J.; Albanesi, G.L.; Ortega, G. 2008. New records of late Tremadocian (Early Ordovician) conodonts and graptolites from the Eastern Cordillera, Jujuy Province, Argentina. Geologica Acta 6 (2): 131-145.

Zeballo, F.J.; Albanesi, G.L. 2013. New conodont species and biostratigraphy of the Santa Rosita Formation (upper Furongian-Tremadocian) in the Tilcara Range, Cordillera Oriental of Jujuy, Argentina. Geological Journal 48 (2-3): 111-292.

Zimbelman, D.R.; Rye, R.O.; Breit, G.N. 2005. Origin of secondary sulfate minerals on active andesitic stratovolcanoes. Chemical Geology 215: 37-60.

Zimmermann, U. 1999. Sediment petrographische, geochemische und isotopengeochemische Methoden zur Bestimmungder Beziehung von Provenienz und Ablagerungsrauman aktiven Kontinentalräandern: Das ordovizische Back-Arc-Becken in der Süd-Puna, Hochland im Nordwesten Argentiniens. Ph.D. Thesis (Unpublished). University of Heidelberg: 282 p. Germany.

Zimmermann, U.; Bahlburg, H. 2003. Provenance analysis and tectonic stting of the Ordovician deposits in the southern Puna basin, NW Argentina. Sedimentology 50: 1079-1104.

Manuscript received: March 21, 2016; revised/accepted: January 13, 2017; available online: January 13, 2017. 